\title{
CHARACTERIZATION OF NEW ANTINOCICEPTIVE LIGANDS IN RAT MODEL: PRECLINICAL STUDIES
}

\author{
Ph.D. Thesis
}

Gyula Kovacs, M.D.

Doctoral School of Theoretical Medicine

Supervisor: Gyongyi Horvath, M.D., Ph.D., D.Sc.

University of Szeged

Faculty of Medicine

Department of Physiology

2017

Szeged 


\section{Publications}

Original publications and presentations the present work is based on:

I. Kovacs G, Petrovszki Z, Toth G, Mallareddy JR, Benedek G, Horvath G.

Characterization of antinociceptive potencies of endomorphin-2 derivatives.

Acta Physiologica Hungarica 2012 99;3: 353-6. IF: 0.821, citation 1

II. Petrovszki Z, Kovacs G, Tomboly C, Benedek G, Horvath G.

The effects of peptide and lipidendocannabionids on arthritic pain at spinal level. Anasthesia and Analgesia 2012 114;6: 1346-52. IF: 3,274, citation 4

III. Petrovszki Z, Kovacs G, Benedek G, Horvath G.

Antinociceptive effect of hemopressin and 2-arachidonoyl glycerol at spinal level.

IBRO International Workshop. Szeged, 2012. január 21-23. Ideggyógyászati

Szemle/Clinical Neurosci

IV. Horvath G, Petrovszki Z, Kovacs G, Toth G, Mallareddy JR, Benedek G.

Antinociceptive potency of new, complex endomorphin-2 analogs at spinal level.

A Magyar Élettani, Anatómus, Biofizikai, Mikrocirkulációs és Vaszkuláris Biológiai Társaságok Kongresszusa, 2012. június 10-13. Debrecen,

\section{Other original published}

I. Kovács Gy, Tóth K.

Hátfájás - ami mindenkinek van I. rész.

Praxis 1999 8;5: 37-44.

II. Kovács Gy, Tóth K.

Hátfájás - ami mindenkinek van II. rész.

Praxis 1999 8;6: 43-6.

III. Kovács Gy, Tóth K.

Hátfájás - ami mindenkinek van.

Nővérpraxis 1999 2: 23-9. 
IV. Kovács Gy, Tóth K.

Csigolyaközti fúzió hengeres titán cage alkalmazásával.

Magyar Traumatológia Ortopédia Kézsebészet és Plasztikai Sebészet

2003 46;3: 204-9. citation 1

V. Nagy E, Tóth K, Janositz G, Kiss A, KovácsGy, Horváth Gy.

Az ironmen triatlon hatása a testtartás kontrollra.

Magyar Sporttudományi Szemle 2004 2-3; 43-6.

VI. Nagy E, Toth K, Janositz G, Kovacs G, Kiss A, Horvath G, Angyal L.

Postural controll in athlete sparticipating in an ironmen triatlon.

European Journal of Applied Physiology

2004 92;4-5: 407-13. IF: 1.332, citation 58

VII. Tóth K, Janositz G, Kovács Gy.

Cement nélküli vápával végzett revíziók középtávú tapasztalatai.

Magyar Traumatológia Ortopédia Kézsebészet Plasztikai Sebészet 2009 52;4: 241-

8 .

VIII. Toth K, Janositz G, Kovacs G, Sisak K.

Midterm results of cup revisions using uncemneted acetabular components.

Revista De Ortopedie Si Traumatologie 2010 1;17: 1-7.

IX. Toth K, Janositz G, Kovacs G, Sisak K, Rudner E.

Successful treatment of late Salmonella infectionsin total hip replacement-report of two cases. BMC Infections Diseases 2010 10;1: 160. IF: 2.825, citation 10

X. Klára T, Janositz G, Kovács Gy, Csönge L, Csernátony Z, Lacza Zs.

Humán albuminnal kezelt liofilizált strukturális allograftokkal szerzett sebészi tapasztalatok.

Magyar Traumatológia Ortopédia Kézsebészet Plasztikai Sebészet 2012 55;4: 2518 .

XI. Klara T, Janositz G, Kovacs G, Csonge L, Csernatony Z, Lacza Zs.

Albumin coated structural lyophilized bone graft: A clinical report of 10 cases.

Cell and Tissue Banking 2014;15: 89-97. IF: 0,965, citation 8

XII. Kovács Gyula

Felnöttek könyökfájdalmának kivizsgálása.

Orvostovábbképző Szemle 2015 21;11: 68-72. 


\section{Contents}

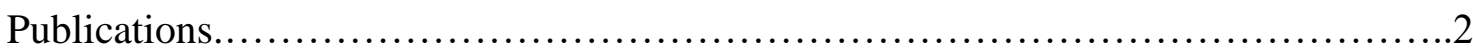

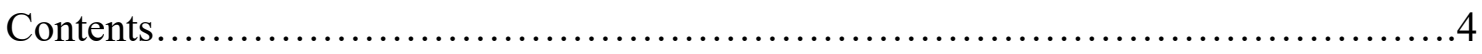

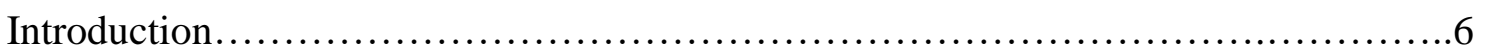

The sensory neuron......................................................6

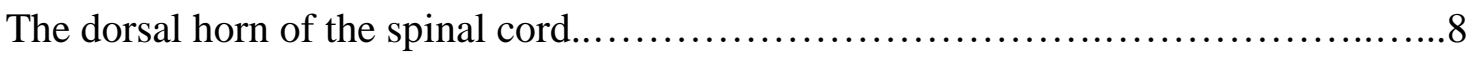

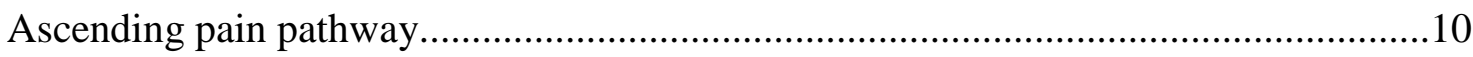

Descending pain pathway................................................ 14

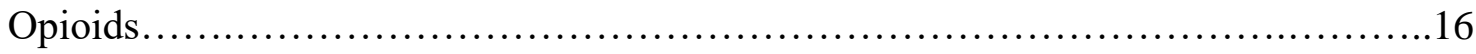

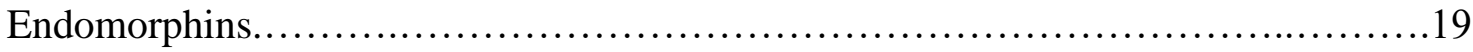

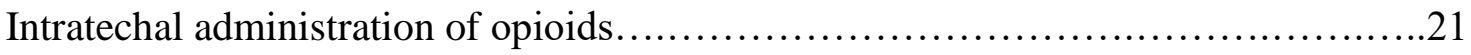

Pharmacokinetics of epidural and intrathecal opioid.............................22

Side-effecect with intrathecal and epidural opioids ................................23

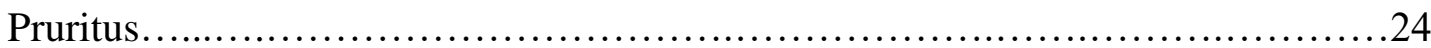

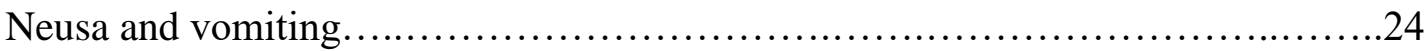

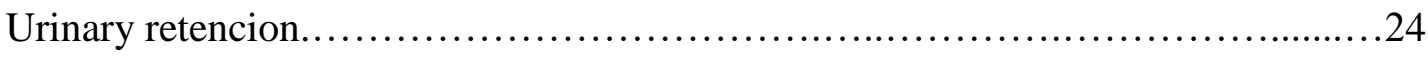

Respiratory depression..................................................25

Psychogenic side effects...............................................26

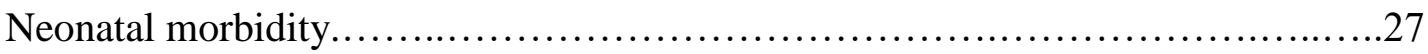

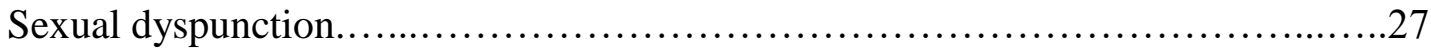

Gastrointestinal functio................................................... 27

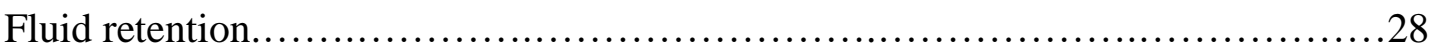

Catheter tip granuloma................................................. 28

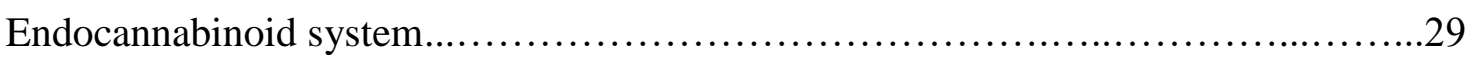

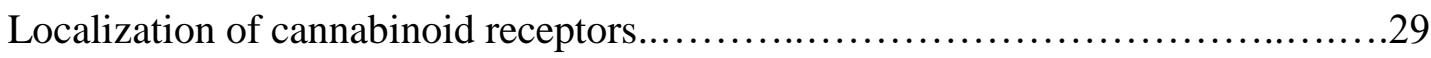

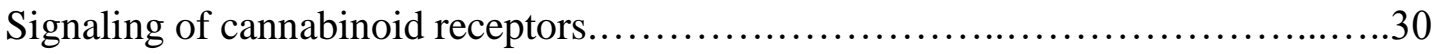

Transient receptor potencial hannels.......................................... 31

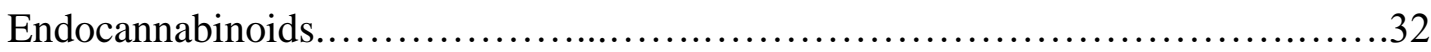

Hemopressin....................................................... 35 


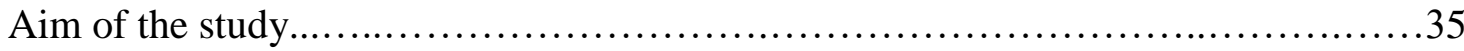

Materials and Methods......................................................... 36

Animal experiments............................................................

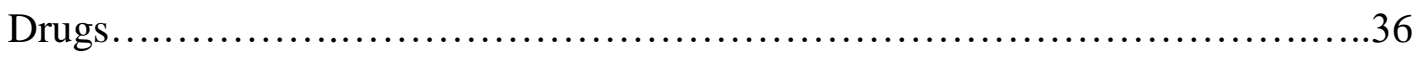

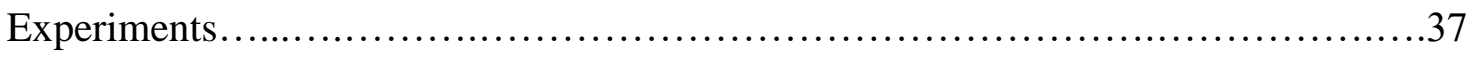

Intrathecal catheterization.................................................... 37

Induction of inflammation................................................ 39

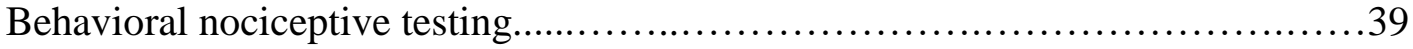

Experimental protocols...................................................40

Statistical analysis...................................................... 41

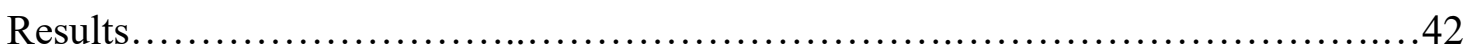

Joint edema............................................................ 42

Mechanosensitivity........................................................42

Discussion................................................................ 49

General conclusions......................................................... 56

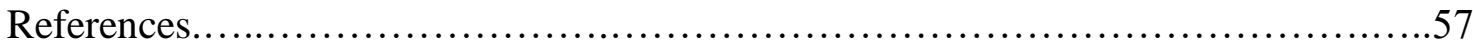

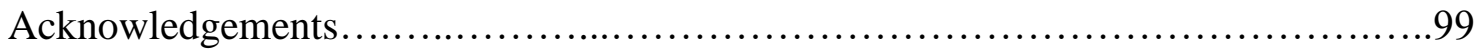

Abbreviations................................................................. 100 


\section{Introduction}

Pain is a crucial part of our life, a vital signal about the effects which may damage our body.

The International Association for Study of Pain (IASP) defines pain as "an unpleasant sensory and emotional experience associated with actual or potential tissue damage or described in terms of such damage" (Merskey and Bogduk1994). Furthermore, the IASP declaredin 2010 that adequate pain management is a fundamental human right, mentioned chronic pain as a separate entity, and determined pain management as an independent specialty in medical science, which requires adequate training and resources (Declaration of Montreal, 2013).

Pain management, especially chronic pain, is a major public health problem, which is associated with devastating consequences to patients and families, a high rate of health care utilization, and huge society costs related to loss in work productivity. The NHS spent 5 billion pounds on treating pain in adolescents, whilst this cost was only 500,000 pounds in 1993 (British Pain Society www.britishpainsociety.org).

Opioids have been regarded for millennia to be among the most effective drugs for the treatment of pain. Their use in the management of acute severe pain and chronic pain related to advanced medical illness is considered to be the standard of care in most of the world. However, long-term opioid treatment in chronic non-cancer pain (CNCP) continues to be controversial, but the new guidelines suggest their administration in these cases, too (Trescot et al., 2008). The incidence and severity of side effects of opioids may play an important role in the success or failure of pain management in patients. Thus, the development of new ligands with fewer side effects has been effective and increased the safety of the treatment.

\section{The sensory neuron}

Pain perception starts from the activation of nociceptive receptors on the primary sensory neurons. Nociceptors are free nerve endings. The received information is transmitted from the periphery to the spinal cord and brainstem. The body of these 
neurons are localized in the dorsal root ganglion (DRG) and in the sensory ganglia of some cranial nerves, such as V, VII, IX and $\mathrm{X}$ also contain a small number of sensory fibers, and these are related to the pain sensation.

DRG contains different types of neurons. The widely accepted classification of these cells is to differentiate large and small categories (Lieberman, 1976; Lawson et al., 1979). Early studies stated that large cells were lightly stained, and small cells were darkly stained (Ramón y Cajal, 1909; Nissl, 1984). Immunostaining techniques revealed two population of the cells, one staining lightly with sizes spanning the whole range, and the other darkly staining and being only small (Lawson et al., 1974; Lawson et al., 1979).

The subdivision of DRG cells may also be based on the degree of myelinization of their axons. The conduction speed of action potentials depends on the diameter of the fiber (Thomas et al., 1993). There are four main types of sensory fibers in the peripheral nervous system: $A \alpha-, A \beta-, A \delta-$, and C-fibers. $A \alpha$ nerve fibers carry information related to proprioception. The diameter of A $\alpha$-fibers is $13-20 \mu \mathrm{m}$, and they are able to conduct action potential fast $(80-100 \mathrm{~m} / \mathrm{s})$. A $\beta$-fibers are large in diameter $(6-12 \mu \mathrm{m})$ and highly myelinated, thus allowing them to quickly conduct action potentials $(35-75 \mathrm{~m} / \mathrm{s})$ from the periphery to central terminals. These fibers have low activation thresholds and normally respond to light touch and are responsible for conveying tactile information. A $\delta$-fibers are smaller in diameter $(1-5 \mu \mathrm{m})$ and thinly myelinated, making them slower conducting $(5-35 \mathrm{~m} / \mathrm{s})$ than $\mathrm{A} \beta$-fibers, and they also possess higher activation thresholds. They respond to both thermal and mechanical stimuli. C-fibers are the smallest type of primary afferents $(0.2-1.5 \mu \mathrm{m})$ and are unmyelinated, thus making them the slowest conductors $(0.5-2 \mathrm{~m} / \mathrm{s})$. It should be highlighted that not all of the $\mathrm{C}$ and A-fibers are nociceptors.

The signals from the A $\delta$-fibers reach the spinal cord before those from the $\mathrm{C}$ fibers; therefore, the painful stimuli evoke two distinct painful sensations. Stimulation of the $\mathrm{A} \delta$-fibers evokes sharp pricking pain sensation, whereas the activation of C-fiber leads to dull, aching, burning pain. Thus a biphasic subjective response could be observed: a short-latency pricking pain is followed by a second long latency pain of a burning and less bearable quality (Bishop et al., 1958).

The neurons activated by noxious stimuli can be classified according to the modalities that activate them. Thus, there are somatic and visceral nociceptors, mechanical, 
thermal (cold and warm), mechano-thermal, polymodal and silent nociceptors. Mechanical nociceptors are activated by high pressure, thermal nociceptors respond to extreme cold or hot temperature $\left(>45^{\circ} \mathrm{C}\right.$ or $\left.<5{ }^{\circ} \mathrm{C}\right)$, and mechano-thermal nociceptors respond to both stimuli. Several authors have reported on A $\delta$ mechano-thermal nociceptors, but the heat threshold of these receptors is higher than that of the $\mathrm{C}$ polymodal nociceptors (Iggo and Ogawa, 1971; LaMotte and Thalhammer, 1982). Kajander has given account of $\mathrm{A} \delta$ mechano-thermal nociceptors, which respond to intense cold stimuli; their thresholds are between 14 and $-18{ }^{\circ} \mathrm{C}$ (Simone and Kajander, 1996). Polymodal nociceptors can be activated by noxious thermal, mechanical, and chemical stimuli, and they are unmyelinated $\mathrm{C}$ fibers. The viscera contain silent nociceptors, which are not activated by noxious stimuli until their firing threshold is reduced by chemical stimuli, for example during inflammation.

\section{The dorsal horn of the spinal cord}

Nociceptors enter the spinal cord through the dorsal roots and proceed in Lissauer's tract one or two segments up or down the spinal cord before penetrating the grey matter of the dorsal horn $(\mathrm{DH})$, where they synapse on secondary neurons.

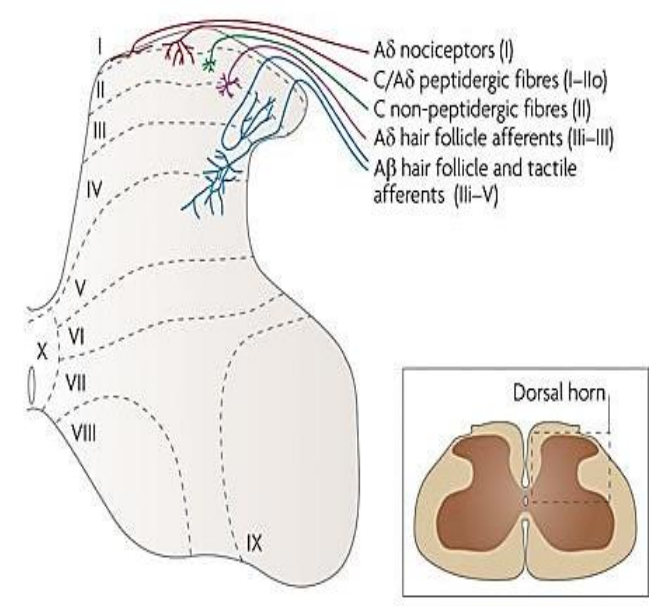

Figure 1. Neuronal circuitry for pain processing in the dorsal horn (Todd A.J.)

The structure of the DH was first presented by Rexed et al. (1952). Structurally it is distinguished into ten different zones on the basis of cytological features of its resident neurons. Classes of primary afferent neurons that convey distinct modalities terminate 
in distinct laminae of the DH (Fig.1). Thus, there is close correspondence between the functional and anatomical organization of neurons in the $\mathrm{DH}$.

The spinal cord itself contains various neuronal cell types depending on their specific synaptic inputs, have different properties, and respond to different types of sensory information.

The vast majority of neurons in laminae I-III have axons that remain in the spinal cord and arborise locally are defined as interneurons. Regarding the neurotransmitters released from these neurons as excitatory, glutamatergic, and inhibitory, GABAergic interneurones are detected, and they can increase or decrease the response of nociceptive-specific (NS) cells and wide dynamic range neurons (WDRs), thus influencing the output of the DH. Both inhibitory and excitatory interneurons, which affect the nociceptive signal, are known. When activated, these interneurons release either enkephalin or dynorphin (endogenous opioid neurotransmitters), which bind to $\mathrm{mu}$ opioid receptors on the axons of incoming $\mathrm{C}$ and $\mathrm{A}-\delta$ delta fibers carrying pain signals from nociceptors activated in the periphery (Tsou et al 1964).

There were several attempts to classify interneurons, but no scheme has been accepted generally, which covers all of these cells. Laminae II interneurons have been investigated extensively by Perl, and four main classes have been identified: islet, central, vertical and radial cells, with different dendritic morphology (Grundt and Perl, 2002). Investigation of the different cell types revealed that islet cells were invariably GABAergic, radial, and most of the vertical cells were glutaminergic, and central cells could be of either type (Todd et al., 1989; Lu and Perl, 2005).

Different morphological studies have been reported on substantial population of "unclassified" cells (Grudt and Perl, 2002; Yasaka et al., 2007; Maxwell et al., 2007). However, there are some evidence revealed that non-neural cell types within the spinal cord (astrocyta, microglia) are also able to influence the pain transmission, particularly under pathological conditions (Coyle, 1998).

The other group of neurons of the dorsal horn was described as projection neurons. These neurons are localized in laminae I and scattered throughout laminae III-VI, with very few present in laminae II. The one type of projection neurons, called NS cells are mostly found superficially and synapsed with A $\delta$ - and C-fibers only. The NS cells are activated only noxious heat or noxious mechanical stimuli or both. The other type of projection neurons, called WDR neurons, receives input from all three types of sensory 
fibers; therefore, they respond to the full range of stimulation, from light touch to noxious pinch, heat, and chemicals (D’Mello and Dickenson, 2008).

In general, myelinated low-threshold mechano-receptive afferents arborise in an area extending from laminae IIi (the inner zone of laminae II) - VI, whereas nociceptive and thermoreceptive $\mathrm{A} \delta$ - and peptiderg $\mathrm{C}$ afferents innervate laminae I and much of laminae IIo (the outer zone of laminae II), except for its most ventral part (Todd, 2002). At the same time, most of nonpeptiderg C-fibers end on interneurons of the inner layer of lamina IIi (Basbaum et al., 2009). Laminae III and V receive inputs from A $\beta$ fibers, which typically transmit innocuous sensory inputs. The WDR neurons of lamina V receive inputs from $\mathrm{A} \delta$ nociceptors and receive indirect inputs from $\mathrm{C}$ fibers (lamina II). Laminae I projection neurons are not a homogeneous group. Dendrites of lamina I projection neurons generally remain within the lamina, and based on their orientation and branching pattern, the cells have been classified into fusiform, pyramidal, and multipolar types (Spike et al., 2003; Almarestani et al., 2007).

\section{Ascending pain pathway}

Several pathways transmit nociceptive information to a higher brain center The main supraspinal targets for laminae I projection neurons include the caudal ventrolateral medulla (CVLM), the nucleus of the solitary tract (NTS), the lateral parabrachial area $(\mathrm{LPb})$, the periaqueductal grey matter $(\mathrm{PAG})$, and certain nuclei in the thalamus (Gauriau and Bernard, 2004).

Many DH projection neurons have axons that cross the midline and travel rostrally in the contralateral white matter to terminate in various brainstem and thalamic nuclei, forming a collection of pathways. This anterolateral system consists of the spinothalamic-, spinoreticular-, spinomesencephalic-, cervicothalamic- and spinohypothalamic tracts.

The spinothalamic tract (direct pathway) is the most prominent ascending nociceptive pathway in the spinal cord. The spinothalamic tract transmits not only nociceptive imput, but also thermal and nondiscriminatory (crude) touch input. Since the spinothalamic tract is phylogenetically a newer pathway, it is referred to as the neospinothalamic pathway. It comprises the axons of nociceptive-specific and wide- 
dynamic-range neurons in laminae I and V-VII of the dorsal horn. These axons project to the contralateral side of the spinal cord and ascend in the anterolateral white matter, terminating in the thalamus. However, many first order neurons synapse with spinal cord interneurons that are associated with reflex motor activity. This tract ascends through the medulla, pons and midbrain and terminates on the ventrobasal complex of the thalamus, and after the relay, axons pass to the somatosensory cortex. The pain fibers of the spinothalamic tract end primarily in the ventroposterolateral (VPL) nucleus, intralaminar nucleus and ventroposteroinferior (VPI) nucleus of the thalamus, some fibers keep to reticular formation. The fibers of trigeminal nuclei terminate in the ventroposteromedial (VPM) nucleus of the thalamus. The axons of these nuclei reach the primary and secondary somatosensory cortex (SI, SII). Approximately $15 \%$ of nociceptive fibers project directly to the thalamus whereas $85 \%$ project to the thalamus via a relay in the reticular formation (Kandel et al., 2000, Patestas and Gartner 2013).

The spinoreticular tract (indirect patway) transmit nociceptive, thermal, and nondiscriminatory (crude) touch signals from the spinal cord to the thalamus indirectly, comprises the axons of neurons in the laminae V, VII and VIII and also laminae I and $X$. It ascends in the anterolateral quadrant of the spinal cord and terminates in the reticular formation of the medulla and pons, and after synapses it projects to the thalamus (intralaminar nuclei) and the hypothalamus, limbic cortex, insular and anterior cingular cortex (ACC). In addition, there are some second order neurons from the DH that bypass the reticular formation and relay sensory input from $\mathrm{C}$ fibers directly to the intralaminar nuclei of the thalamus. In contrast to the spinothalamic tract, many of the axons of the spinoreticular tract do not cross the midline (Kandel et al., 2000). Since the spinoreticular tract is phylogenetically an older patway, it is reffered to as the paleospinothalamic pathway. This tract is involved in the motivational-affective characteristics, as well as the neurovegetative responses to pain. This tract also activates the structures of the brainstem, thus is responsible for the descending suppression (Kandel et al., 2000, Patestas and Gartner 2013).

The spinomesencephalic tract contains the axons of neurons in laminae I, II, IV, V, VI, VII and X. It projects in the anterolateral quadrant of the spinal cord to the mesencephalic reticular formation and PAG, nucleus raphe magnus (NRM) via the 
spinoparabrachial tract, and it projects to the parabrachial nuclei (PBN). Since neurons of the PBN project to amygdala, which is the major component of the limbic system, this tract is thought to contribute to the autonomic, cardiovascular, motivational and affective responses to pain. Most axons of this pathway project in the dorsal part of the lateral funiculus. This may be the explanation why pain persists or returns after anterolateral cordotomy (Kandel et al., 2000).

The spinohypothalamic tract comprises the axons of neurons in laminae I, V and VII. It projects directly to the supraspinal autonomic control centers in the hypothalamus and is thought to activate complex neuroendocrine and cardiovascular responses (Kandel et al., 2000).

The cervicothalamic tract originates in neurons of lateral cervical nucleus, located in the lateral white matter of the upper two cervical segments of the spinal cord. The lateral cervical nucleus receives input from nociceptive neurons in laminae III and IV. Many of the axons in the cervicothalamic tract cross the midline and ascend in the medial lemniscus of the brainstem to nuclei in the midbrain and to the VPL and VPM nuclei of the thalamus. Some axons from laminae III-IV project through the dorsal column of the spinal cord and terminate in the cuneate and gracile nuclei of the medulla.

The anterolateral system is not the only nociceptive output as is described; the dorsal column system also transmits some of visceral nociceptive information (Palacek, 2004). The nerve fibers of these dorsal column neurons originate from the cell bodies of projection neurons, many of which are located in the vicinity of the central canal and project to the gracile and cuneate dorsal column nuclei and transmit the visceral nociceptive information. Axons from these nuclei then decussate and travel up to the brainstem as the medial lemniscus on the contralateral side.

The trigeminal nerve through the trigeminal ganglion also contributes to the ascending pain pathways. The trigeminal nucleus is divided into three parts, i.e., subnucleus oralis, subnucleus interpolaris and subnucleus caudalis, which is the site where the pain fibers synapse. The fibers from the subnucleus caudalis cross to the opposite side, and join the 
spinothalamic tract and medial lemniscus on their way to the thalamus (Hayashi et al., 1984).

Pain sensationis realized by regular function of the medial and lateral pain system. The medial system is involved mainly in the processing of the emotional unpleasant aspect of the pain, while the lateral system is involved mainly in the processing of the sensory discriminative aspect of the pain (Trede et al., 1999). The role of the medial pain system may be present in asymbolia. In this disorder, the patient is able to recognize the painful stimuli, but the adequate motor and emotional responses are lacking (Bertie et al., 1988). The patient feels pain, but it does not represent something harmful and dangerous.

Functional magnetic resonance imaging (FMRI) studies have revealed that different cortical areas provide significant support for the existence of the medial and lateral pain system (Bantick et al., 2002; Bornhovd et al., 2002). Five major cortical areas are activated consistently to acute pain stimuli: ACC, isnsular cortex, primary somatosensory cortex, secondary somatosensory cortex and prefrontal cortex (PFC). Furthermore, altered activity in several subcortical areas (e.g., brainstem, PAG, hypothalamus, amygdala, hippocampus and cerebellum) is also observed during pain. Some of these regions comprise the so-called "pain neuromatrix" (Melzack, 2001). It exhibits significantly correlated activity with sensory or emotional descriptions of the painful experience, suggesting that they have a significant role in pain generation, but no brain region has been shown to be exclusively activated during pain experiences (Bornhovd et al., 2002), but the damage of the pain matrix by cortical lesions very rarely remove the pain completely (Ploner et al., 1999).

Imaging studies demonstrate that the PFC can regulate the perception and behavioral expression of pain in humans (Wiech et al., 2006). PFC is connected to the limbic systems; therefore, it can regulate the motivational-emotional aspects of pain (Ochsner and Gross, 2005). PFC activity reduces negative emotion by influencing subcortical systems implicated in affective appraisal and learning processes, which in turn has an impact on reported emotional experience (Wager et al., 2008). Wilkonson and colleagues have reported after surgical cingulotomies performed for several pain syndromes that it may reduce emotional or motivational aspect of the pain, but it leaves intact the capacity for nociceptive pain (Foltz et al., 1962; Wilkonson et al., 1999). 
Mazzola et al. have investigated the effect of focal electrical stimuli to somatosensory cortex, and it produced somatosensory sensation such as paresthesia and temperature changes but no pain (Mazzola et al., 2006). Several authors have shown that direct electrical stimulation of the posterior insular region produced pain (Ostrowski et al., 2002; Mazzola et al., 2012). The importance of the posterior insula for nociceptive pain is further suggested by functional imaging studies of pain empathy (Singer at al., 2004), hypnotically induced pain (Raij et al., 2005), and recalled pain experiences (Albenese et al., 2007). The same does not appear to be true of other cortical regions that are also considered part of the pain neuromatrix (Boly et al., 2008). All these have raised the idea that this region may represent a somatotopically organized "pain cortex" (Mazzola et al., 2012).

\section{Descending inhibitory pathway}

It is well known that in certain circumstances pain can be blocked. For example, mainly battle soldiers or injured sports people have reported experiencing no pain despite their severe injuries. This suppression of pain is mediated by the descending pathways (Beecher, 1946; Bingel and Tracey, 2008).

The descending pathways can be found in the dorsolateral funiculus, and they originate in the rostroventral medulla (RVM), the NTS, the PB nuclei, the dorsal reticular nucleus, the PAG the NRM, the hypothalamus, the amygdala, and the cortex (Basbaum and Fields, 1979). Regarding the function of the descending pathways, they may facilitate or block transmission of pain at the level of the DH through releases different neurotransmitters including endogenous opioids, serotonin (5-HT), and norepinephrine (NE) (Ren et al., 2009).

PAG is a key station in the descending pathway. Inputs which originate in PAG are essential to modulate the pain pathway. PAG receives nociceptive inputs from the spinal cord through the PB nucleus and from the cortical regions including the ACC (Gauriau and Bernard, 2002; Heinricher et al., 2009) and amygdala (Bingel and Tracey, 2008). Cui et al. have demonstrated that the release of endogenous 5-HT, NE, and amino acids in the spinal cord are increased during stimulation of the PAG using stimulus intensities that inhibited nociceptive responses of the DH neurons. Several studies have shown that 
PAG is a source of descending opioid mediated inhibition of nociceptive inputs (Tsou and Jang, 1964; Gao et al., 1997; Waters and Lumb, 1997). The findings provide direct evidence that the antinociception produced by the stimulation of PAG is accompanied by an activation of serotonergic, noradrenergic and glycinergic neurons (Cui et al., 1999).

Several studies have revealed that the RVM produces pain modulation as it can enhance or inhibit nociceptive inputs (Fields, 2000). Electrophysiological studies which investigated RVM have revealed that it has neurons that increased firing immediately prior to the tail-flick (TF) response; they were labelled as "on-cell" and those that paused fire labelled as "off-cells" while those cells in which no detectable changes were found were labeled "neutral cells" (Fields et al., 1983, 1995). Opioid microinjection into RVM disinhibited off-cells and increased the activity of neurons (Fields, 2004). The oncells of RVM are directly inhibited by opioids and are activated by cholecystokinin (CCK) via the $\mathrm{CCK}_{2}$ receptor (Heinricher and Neubert, 2004). GABA can inhibit offcells so they are likely to be modulated by inhibitory GABAergic interneurons or by GABAergic projection from the PAG (Gilbert and Franklin, 2001; Moreau and Fields, 1986).

RVM contains serotonergic neurons that project to the spinal cord from NRM and the nucleus paragigantocellularis (Yaksh and Wilson, 1979; Kwiat and Bisbaum, 1992; Cui et al., 1999). 5-HT(serotonin) released from the NRM descends to the DH, where it forms excitatory connections with the "inhibitory interneurons" located in Laminae II. Furthermore, the receptor subtype can influence the effect of serotonin (Dogrul et al., 2009). Intrathecal (i.t.) administration of serotonin antagonist caused the activation of different 5-HT subtypes; thus, 5- $\mathrm{HT}_{2} \mathrm{~A}$ and 5- $\mathrm{HT}_{3}$ facilitated nociception, and 5- $\mathrm{HT}_{1} \mathrm{~A}$, 5-HT ${ }_{1} \mathrm{~B}, 5-\mathrm{HT}_{1} \mathrm{D}$ and 5-HT7 subtypes were inhibitory (Sasaki et al., 2006).

Investigation of the neurons of RVM revealed that about $20 \%$ of the neurons that project to the DH are serotoninergic, and the residual $80 \%$ are likely glycerinergic or GABAergic (Kato et al., 2006).

In addition to electrical or chemical stimulations of the PAG or RVM to elicit antinociception, the level of NE in the cerebrospinal fluid is increased (Cui et al., 1999). Because norepinephrine-containing neurons are not found in the PAG and RVM, non- 
catecholamine neurons must project to it and activate spinally projecting catecholamine neurons located in the pons locus coeruleus (LC) A5, A6, and medulla A7 (Bajic et al., 1999; Odeh and Antal, 2001).

The role of dopamine in the descending inhibition has also been demonstrated (Wood, 2008). This pathway is originated from hypothalamic A 11 nuclei and ended directly in the DH. The inhibitory role of dopamine on evoked pain via activation of D2-like receptors at the level of dorsal horn has also been described (Lapirot et al., 2011).

\section{Opioids}

The demand to decrease pain is as old as human history. The selection of different drugs has been done by experimental ways during several millennia.

The Sumerians in Mesopotamia were among the first people identified to have cultivated the poppy plant around 3400 BC. They called it Hul Gil, the "joy plant". It eventually spread throughout the ancient world to every major civilization in Europe and Asia and was used to treat pain (Booth, 1986). A German pharmacist, Sertürner (1803) isolated a pure substance from opium, and called it morphine after the Greek god of dreams, Morpheus (Simone 1973). Despite the advantageous features of opioids, their actions were largely unknown. In the 1960s, Tsou and Jang performed a pioneering work in understanding the mechanism through the direct microinjection of morphine into the brain to produce analgesia (Tsou and Jang, 1964). The high potency and specificity of morphine suggested that it might bind to specific receptors in the nervous system to induce their biological effects.

The milestone of research was in 1973 when the first descriptions of the pharmacological properties of morphine, along with other agonists and antagonists, at the level of the receptor were reported (Pert et al., 1973). The action of opioid compounds is mediated through activation of specific opioid receptors. Three major opioid receptor families, the $\mu-, \kappa-$, and $\delta$-opioid receptors, were cloned in the early 1990s (Law and Loh, 1999; Pasternak, 2004) and a fourth member of the opioid receptor family, nociceptin or orphanin FQ receptor (NOP) or the opioid receptor-like orphan receptor (ORL) was added to the list in 1994 (Mollereau et al., 1994; Meunier et al., 1995). NOP receptor has nucleotide and amino acid homology to the other opioid receptors. It has been identified that this homology is $52 \%$ to $\delta$-opioid receptor, $54 \%$ to 
$\mu$-opioid receptor and 52\% to $\kappa$-receptors in rat (Wang et al., 1994). The development of novel opioid analogs that elicited different biological effects gave way to the detection of pharmacological subtypes of mu-opioid receptor (MOR), delta-opioid receptor (DOR) and kappa-opioid receptor (KOR), although the molecular basis of these subtypes has not yet been established (Traynor, 1989; Zaki et al., 1996). Genetic and physiological variations influence the sensitivity of MOR towards different $\mu$-opioid ligands and difference in their potency across various species and animal strains (Pasternak, 2004), which led to the proposal that receptors could be classified as MOR1, MOR2, and MOR3. Several studies have revealed evidence from binding studies in guinea-pig cerebellum that suggested the existence of four KOR subtypes, KOR1a, KOR1b, KOR2 and KOR3, based on pharmacological studies (Clark et al., 1989; Caudle et al., 1998). In addition, DORs exist at least in two subtypes, DOR1 and DOR2, according to their pharmacological attributes (Traynor, 1993; Zaki et al., 1996). The MOR, KOR and DOR main types are the most studied, each playing a different role in pain: MOR generates the most profound analgesia, but it is also associated with constipation, respiratory depression, euphoria, tolerance, dependence and addiction (Schmauss and Yaksh, 1984; Cowan et al., 1988), DOR is involved in pain relief from thermal sources (Mansour et al., 1988) but like the MOR, it is also associated with respiratory depression and addiction (Abdelhamid et al., 1991, Maldonado et al., 1992). KOR mediates pain originating in chemical stimuli (Leighton et al., 1987; Wollemann et al., 1993), but it promotes dysphoria, diuresis and sedation (von Voigtlander et al., 1983; Lahti et al., 1985).

Opioid receptors are members of the superfamily of seven helix transmembrane (TM) proteins known as G-protein coupled receptors (GPCRs). Opioid receptors are composed of three domains: an extracellular N-terminus, seven TM $\alpha$-helices, and an intracellular C-terminus. Across the receptors, the intracellular loops share the highest sequence homology (90\%) followed by TM domains (70\%), while the $\mathrm{N}$ - and C-termini show the greatest diversity (Knapp et al., 1995). Coupling between the receptors and Gproteins occurs via the pertussis toxin sensitive $\mathrm{G} \alpha$ unit. Agonist-dependent opioid receptor activation induces conformational changes in the receptor, which promote exchange of Ga-bound GDP for unbound GTP followed by dissociation of the Gproteins from the receptor. The $\mathrm{G} \alpha$ unit further dissociates from the G $\beta \gamma$ units. Signal transduction occurs via GTP-bound Ga inhibiting adenylate cyclase responsible for 
producing cyclic adenosine monophosphate (cAMP). Down-regulation of cAMP results in the reduction of voltage-dependent currents and neurotransmitters release (Eguchi, 2004). The $G \beta$ and $G \gamma$ subunits also play key roles in decreasing cell excitability by inhibiting voltage-gated $\mathrm{Ca} 2+$ channels, hyperpolarizing the membrane and upregulating the conduction of potassium (Eguchi, 2004). This combined decrease in neurotransmitter release and excitability is manifested as analgesia. Finally, the inactive state is re-constituted when Ga-bound GTP is hydrolyzed to GDP, re-association with $\mathrm{G} \beta \gamma$ and recoupling with the receptor.

Opioid receptors are expressed in several levels of pain-modulating descending pathways. These include the spinal cord, pons, midbrain, brainstem, limbic system, and cortical structures. Opioid receptors exist not only in the nervous system (Xia and Haddad, 1991; Vogt et al., 1995) but also in peripheral organs, such as the heart, lungs, liver, and the gastrointestinal (GI) and reproductive tracts (Wittert et al., 1996). However, the expression and distribution of these receptors vary significantly among different organs. Brain stimulation in certain areas, particularly the PAG, caused pronounced analgesia (Mayer and Liebeskind, 1974) that was blocked by the opioid antagonist naloxone (Akil et al., 1976). These observations strongly suggest the existence of endogenous opioids in the brain, so one or more endogenous neurotransmitters acting on the opiate receptors have to exist. The results of studies in the 1970s identified two enkephalin pentapeptides, namely $\left[\mathrm{Met}^{5}\right]$ enkephalin $(\mathrm{H}-\mathrm{Tyr}-$ Gly-GlyPhe-Met-OH) and [Leu ${ }^{5}$ enkephalin (H-Tyr-Gly-Gly-Phe-Leu-OH) (Hughes et al., 1975), followed closely by the identification of $\beta$-endorphin (Li et al., 1976; Doneen et al., 1977) and dynorphin (Goldstein et al., 1979) in brain tissue. In 1995, an endogenous agonist for the opioid receptor-like orphan receptor (ORL) was isolated concurrently by two independent groups, which was termed ORL-1 by Mollereau et al. in 1994 and Meunier et al. in 1995, and orphanin FQ by Reinscheid et al. in 1995. Although nociceptin structurally closely resembles dynorphin, which is an endogenous $\kappa$ - receptor ligand, nociceptin has almost no affinity for other opioid receptors (Gintzler et al., 1997). Mogil et al. have established that orphanin functionally antagonizes $\mu-, \delta$-, and $\kappa$-opioid receptors, and may play a general role in opioid modulation after intracerebroventricular (i.c.v.) administration in rats (Mogil et al., 1996). Two years later, endomorphin-1 (EM-1) (Tyr-Pro-Trp-Phe- $\mathrm{NH}_{2}$, ) and -2 (EM-2) (Tyr-Pro-PhePhe- $\mathrm{NH}_{2}$ ), endogenous MOR agonists with very high affinity and selectivity were 
synthesized and subsequently isolated by Zadina in bovine and human brain extracts (Zadina et al., 1997; Hackler et al., 1997).

The structure of most naturally occurring peptide opioids can be divided into two components: the biologically important N-terminal tri- or tetrapeptide fragment ("message sequence") and the remaining C-terminal fragment ("address sequence") (Yamazaki et al., 1993). The message sequence provides information for signal transduction that leads to the biological response, while the address domain primarily influences binding affinities and accommodates the elements of selectivity.

\section{Endomorphins}

Zadina' group discovered and identified a new biologically sequence, Tyr-Pro-Trp-Phe$\mathrm{NH}_{2}$, in bovine brain (Zadina et al.1977) and human cortex (Hackler et al.1977).

The new peptide, which was named EM-1, showed remarkable affinity for the $\mu$-opioid receptor and selectivity for the $\mu$-opioid receptor over the $\delta$ - and $\kappa$-opioid receptors. The other peptide, EM-2, which differs by one amino acid from endomorphin-1, was also isolated. EM-2 was shown to be almost as potent as EM-1 (Hackler et al., 1997; Zadina et al., 1997).

The results of several in vitro (Kakizawa et al., 1998; Goldberg et al., 1998, Fichna et al., 2006) and in vivo (Horvath, 2000; Sakurada et al., 2001; Tseng, 2002) studies have displayed that the $\mu$-opioid receptors are exclusive binding sites for endomorphins (EM). These EMs were displaced by naloxone, Tyr-D-Ala-Gly-MePhe-Gly-ol (DAMGO) and other $\mu$-opioid receptor-selective ligand in a concentration-dependent manner (Horvath, 2000). Moreover, Sakurada and Tseng have revealed that there are functionally two diverse subtypes of $\mu$-opioid receptors: $\mu_{1}$ and $\mu_{2}$, which might be responsible for their distinct pharmacological activity (Sakurada et al., 1999; Tseng et al., 2000). The $\mu_{1}$-opioid receptor antagonist naloxone was shown to block the antinociception induced by i.c.v. administration of EM-2 more effectively than EM-1, whereas $\beta$-funaltrexamine inhibited both. The assays revealed that $\mu_{2}$-opioid receptors would be stimulated by both EM-1 and EM-2, whereas $\mu_{1}$-opioid receptors would be stimulated only by EM-2.

The structures of traditional opioid peptides (endorphins, enkephalins, and dynorphins) contain Tyr-Gly-Gly-Phe sequence at the $\mathrm{N}$ terminus, whereas the structures of EM-1 
and EM-2 are quite distinct. The N-terminal message sequence is composed of two pharmacophoric amino acid residues, Tyr and Phe (only in the case of EM-1 Phe is replaced by Trp), in which the amino and phenolic groups of Tyr and the aromatic ring of Phe (or Trp) are required for opioidreceptor recognition. This sequence also includes a spacer residue(s), which join(s) the pharmacophoric residues of the message sequence (Podlogar et al., 1998; Paterlini et al., 2000; Janecka et al., 2004).

The localization of EMs has been investigated by several assays in human and animal models (Hackler et al., 1997; Martin-Schild et al., 1998, 1999; Pierce et al., 1998, Pierce and Wessendorf, 2000). These analyses have revealed that EMs can be detected indifferent areas of brain such as the stria terminalis, the PAG, the LC, the PB nucleus, and the NTS. EMs have also been detected in the spleen, thymus and blood (Jessop et al., 2000) and in immune cells in inflamed subcutaneous tissue (Mousa et al., 2002).

However, there are differences in the neuroanatomical localization of these peptides. EM-1 is widely and densely distributed throughout the brain and upper brainstem, and is particularly abundant in the nucleus accumbens (NAC), the cortex, the amygdala, the thalamus, the hypothalamus, the striatum, and the DRG (Schreff et al., 1998; MartinSchild et al., 1999).

In contrast, EM-2 is more prevalent in the spinal cord and lower brainstem (MartinSchild et al., 1999; Pierce and Wessendorf, 2000), EM-2-immunoreactive (IR) cell bodies are prominent in the hypothalamus and the NTS, endomorphin-2-IR varicose fibers are mainly observed in the substantia gelatinosa of the medulla and the DH. More modest endomorphin-2 IR has been seen in the NAC, substantia nigra, NRM, ventral tegmental area (VTA), and pontine nuclei and amygdala. The different distribution of EM-1 and EM-2 in the nervous system suggests that EM-2 may play a role in the earliest stages of nociceptive information (Zadina, 2002). Mousa has revealed that EM2 exists in the spinal cord in the superficial layers of the $\mathrm{DH}$, and in the primary afferent fibers (Mousa et al., 2002). Moreover, these are the regions with highest density of $\mu$ receptors in the nervous system (Martin-Schild et al., 1997).

Several assays have investigated the role of EMs in the modulation of nociceptive transmission after i.c.v., i.t., and intraperitoneally (i.p). administration (Li et al., 1976; Tseng et al., 1991; Sawynok et al., 1991; Hung et al., 2003). These results confirm that the adrenergic pathway is more important than the serotoninergic pathway in mediating the antinociception activated by supraspinally administered EMs. Li has demonstrated 
that EM-1 produced dose-dependent, naloxone-reversible analgesia after i.p. administration in rats. The peak analgesic effect appeared later than after central (i.c.v. and i.t.) administration ( $\mathrm{Li}$ et al., 1976). The explanation is their rapid enzymatic degradation in peripheral tissues and low permeation through the brain-blood barrier (Spampinato et al., 2003). Tseng has demonstrated that both EM-1 and EM-2 given supraspinally produce their antinociception by the stimulation of MOR. However, the antinociception induced by EM-2 given supraspinally contains an additional component, which is mediated by the release of dynorphin A (1-17) as well as Metenkephalin, acting on KOR and DOR (Tseng et al., 2000). This accounts for the differences in the antinociceptive effects between EM-1 and EM-2.

EM-2 could serve both a regulatory function by hyperpolarizing the membranes on intrinsic neurons of the $\mathrm{DH}$ and decreasing the excitability of postsynaptic neurons $(\mathrm{Wu}$ et al., 1999), and an autoregulatory function by limiting the release of excitatory transmitters, glutamate (Glu), substance P, GABA, glycine, and calcitonin gene-related peptid (CGRP) through the activation of presynaptic $\mu$-opioid autoreceptors from the primary afferent fibers (Yajiri and Huang, 2000; Wu et al., 2003; Silverman et al., 2005).

A major goal in opioid peptide research is the development of novel analgesics that could substitute morphine without its well-known side effects (Olson et al., 1998).

\section{Intrathecal administration of opioids}

In neuroaxial anesthesia, parts of the local anesthetic is placed around the nerves of the central nervous system, such as spinal anesthesia (intradural or subarachnoid anesthesia) and epidural anesthesia. James Leonard Corning (1885) was the first who injected cocaine between the spinosus process of the lower lumbar region (Corning, 1985). Some years later, the German surgeon, August Bier (1889), performed surgery during spinal anesthesia (Bier, 1889). The first published article on opioids for i.t. analgesia belongs to Nicolae Racoviceanu-Pitesti, a Romanian surgeon, who used a mixture of cocaine and morphine in 1901 (Brill et al., 2003). Fidel Pagés, a Spanish military surgeon developed the modern technique of lumbar epidural anesthesia (Pagés, 1921). His technique was popularized by Achille Mario Dogliotti, who described the "loss of resistance" technique, which facilitates the detection of epidural space (Dogliotti, 1933). 
The first trial which confirmed the efficacy of i.t. opioids in animal models was conducted by Yaksh (Yaksh and Rudy, 1976), who administered morphine directly into the subarachnoid space. The distribution of i.t. catheter tips and the correlation between the location of the catheter tip and the motor and sensory impairments were observed by Dobos. Their results have revealed that detection of the paralytic and/or antinociceptive effect of a small dose of lidocaine before the experiments is a reliable method for prediction of the side position of the catheter tip (Dobos et al., 2003). In 1979, Wang published the first case of i.t. administration of morphine used effectively for pain relief in a human patient with inoperable cancer (Wang et al., 1979). Likewise, in 1979, Behar et al. published a paper in The Lancet on the use of epidural morphine in more than 10 patients (Behar et al., 1979). Onofrio has utilized chronic i.t. morphine infusion to decrease severe pain associated with cancer (Onofrio et al., 1981). Since these publications, i.t. opioids have been applied widely in clinical practice as useful drugs in the treatment of acute and chronic pain. Morphine was the first opioid approved by the US Food and Drugs Administration (FDA) in 2004 for spinal administration (Mugabure Bujedo et al., 2012). Observations has confirmed that the spinal bioavailability of morphine is better than for parenteral administration (the ratio is 1/10) (Bernards, 2004; Mugabure Bujedo et al., 2012); thus, the effective doses depend on the route of administration. The optimal "single shot" i.t. dose appears to be $75-150 \mu \mathrm{g}$, and the ideal "single shot" epidural morphine dose could be $2.5-3.75 \mathrm{mg}$ for the first 24 hours after surgery suggested by the American Society of Anesthesiologist (ASA) (Mugabure Bujedo et al., 2012).

\section{Pharmacokinetics of epidural and intrathecal opioids}

The side effects of i.t. and epidural opioids are caused by the presence of drugs either in the cerebrospinal fluid (CSF) or in the blood (Chaney, 1995). In the spinal cord, opioids ligate specific receptors within the $\mathrm{DH}$ and bind to nonspecific sites in the white matter. Opioids can reach the plasma compartment through venous uptake. Opioids administrated in the epidural space can bind in the epidural fat tissue (Rathmell et al., 2005).

Umenhoffer has investigated the concentration of morphine, fentanyl, sufentanyl within CSF, spinal cord, epidural fat and plasma after lumbar intrathecal administration (Ummenhofer et al., 2000). The fate of opioids after i.t. administration is complex. I.t. 
opioids penetrate directly the spinal cord and via dura mater reach the epidural space. The pharmacokinetics of i.t. administrated opioids depend on its lipophilicity. The lipophilic opioids (fentanyl, sufentanyl) are approximately 800 and 1600 times as lipid-soluble as morphine. Opioids get through the dura rapidly, where they bend to the epidural fat tissue and enter the systemic circulation. However, they rapidly penetrate in the spinal cord, where develop their effect by specific DH receptors, a nonspecific way within the white matter as well as via systemic circulation. Their effect is typically rapid transfer from CSF, rapid onset and prompt decline. The minimal rostral spread explain the lack of the delayed respiratory depression and relatively small dermatomal band of analgesia.

Morphine, as a hydrophilic opioid, crosses the blood-brain barrier slowly, bind to the epidural fat tissue to a lesser extent and more strongly to specific receptors in the gray matter. As compared with lipophilic drugs, morphine presents a slow onset of action, extensive and prolonged rostral spread resulting in delayed respiratory depression and a relative long duration of action (Rathmell et al., 2005). CSF ascends in a cephalad direction reaching the cisterna magna by one or two hours and the ventricles by three or six hours (DiChiro and Dickenson, 1966). After epidural administration of morphine, only $3 \%$ of the dose appeared within the CSF (Sjöström et al., 1987). The epidural space contains considerable venous plexus so the vascular reabsorption is extensive. After epidural administration, the peak concentration of the fentanyl reaches at above five to ten minutes, this value in case of sufentanyl is faster while after morphine administration this peak can be detected only after 10-15 minutes (Ahuja and Strunin, 1985).

\section{Side-effects with intrathecal and epidural opioids}

After 1979, when Behar and Wang confirmed that small doses of morphine given i.t. and epidurally produced long-lasting relief of chronic and postoperative pain, the method was spread widely in the daily practice, but at the same time, side effects were well-known after systemic administration of morphine (Behar et al., 1979; Wang et al., 1979). 


\section{Pruritis}

The most common side effect of i.t. and epidural opioids is pruritis. This symptom occurs more frequently than after systemic administration. It is localized mainly to the face, neck and upper part of thorax. The incidence varies widely. Meta-analyses have shown that 22-37\% of the patients experienced pruritus (Gehling and Thryba, 2009; Meylan et al., 2009). Pruritus is usually typical within a few hours of the administration, and it may precede the onset of analgesia (Bailey et al., 1993). Certain studies have revealed a connection between the dose and the pruritus (Fuller et al., 1990), while others did not affirm this (Bailay et al., 1993). The exact mechanism of opioid-induced pruritus is unclear (Chaney, 1995). The cephalad migration of the morphine in the CSF and interaction with the trigeminal nucleus is crucial (Ballantyne et al., 1988). The fact that the effect can be eliminated by naloxone supports that this effect is an opioid receptor mediated central mechanism (Benstein et al., 1981). Although opioids may liberate histamine from mast cells, it seems unlikely that they are responsible for pruritus, since the antihistamine therapy is not effective against this side effect, and only its sedative effects may decrease the sensation of itch (Bernstein et al., 2001; Chaney, 1995).

\section{Nausea and vomiting}

The incidence of nausea after neuroaxial administration of opioids is approximately $30 \%$ (Chaney, 1995). Meta-analyses have shown that i.t. morphine increased the risk of vomiting and nausea, and this incidence was grater in patients when they were administered fentanyl than morphine (Gehling and Thryba, 2009). The effect probably was caused by the cephalad migration of drug and interaction with opioid receptors located in the area postrema (Borgeat et al., 2003). Sensitization of the vestibular system to motion and decreased gastric emptying produced by opioids may also play a role (Borgeat et al., 2003). Compared to the systemic administration of opioids, i.t. administration does not increase the incidence of nausea and vomiting particularly if the dose is $<100 \mu \mathrm{g}$ (Borgeat et al., 2003).

\section{Urinary retention}

Urinary retention following the i.t. administration of opioid was detected between 080\% (Winkelmuller and Winkelmuller, 1996). An interesting result was published by 
Gehling, who observed urinary retention in $17 \%$ of placebo patients; nevertheless, the i.t. morphine administration did not increase the risk of urinary retention (Gehling and Thryba, 2009). Urinary retention is more common in elderly patients who suffer from an enlarged prostate (Winkelmuller and Winkelmuller, 1996).

The effect can be detected after the administration of the opioid, and it lasts for 14-16 hours, regardless of the dose used (Rawal et al., 1983). The incidence of urinary retention was higher when the morphine was given via i.t. route (Rawal et al., 1983) compared to intramuscular (i.m.) and intravenous (i.v.) administrations (Peterson et al., 1982). The explanation of this effect is the interaction with opioid receptors in the sacral cord, which promotes inhibition of sacral parasympathetic nervous system outflow, thus causing relaxation of the detrusor muscle and an increase in the bladder capacity leading to urinary retention; however, the effect is also reversed by naloxone (Rawal et al., 1983).

\section{Respiratory depression}

The most dangerous side effect of opioids is respiratory depression. However, relevant studies confirm that respiratory depression is infrequent after i.t. administration (Gwirtz et al., 1999; Gehling and Thryba, 2009).

Two types of respiratory depression have been distinguished, i.e., early respiratory depression occurs within 2 hours after morphine administration, and the other is the late depression. According to Ruan, early respiratory depression due to i.t. morphine administration has never been reported (Ruan, 2007). The Swedish Society of Anesthetists organized a nationwide retrospective survey of clinical experience with extradural and i.t. opiates. The results revealed that after i.t. morphine administration, late ventilatory depression was present in $4-7 \%$ of the patients, and after epidural morphine administration, this ratio was 0.25-0.40\% (Gustafsson et al., 1998; Etches et al., 1989; Standl et al., 2001).

The problem in comparing the studies is that how respiratory depression was defined or detected. Respiratory rate may or may not indicate the failure (Ready et al., 1991). Hypercapnia can occur despite a normal respiratory rate (Ready et al., 1988). Pulse oximetry may be valuable, but the results must be taken into account cautiously, when the patient receives supplement oxygen therapy (Bailey et al., 1993). The most reliable clinical sign of significant respiratory depression appears to be a depressed level of 
consciousness (Etches et al., 1989; Ready et al., 1991). Therefore, monitoring the respiratory status is essential to detect respiratory depression. The recommended duration of monitoring is from 18 to 24 hours after i.t. administration of morphine, and from 4 to 6 hours after the administration of i.t. fentanyl or sufentanil (Ready et al., 1991).

\section{Psychogenic side effects}

The psychogenicside effects can be divided into three groups: those that result in a decrease in the level of consciousness-sedation, drowsiness and sleep disturbance, other that affect the thinking process and the ability to react-cognitive impairment, psychomotor impairment, delirium, hallucinations, dreams and nightmares, and third, direct toxic effects of opioids, seizures, hyperalgesia and tolerance (Vella-Brincat et al., 2007).

Sedation is the most frequent mental change after i.t. or epidural administration of opioids (Thompson, 2000). This symptom is most commonly detected after sufentanil administration (Donadoni et al., 1985). The results confirmed the connection between the dose and the clinical sign (Bailey et al., 1993). Coma has also been reported (Sidi et al., 1981; Wells and Davies, 1987). Gustafsson has described the development of euphoria, anxiety, and hallucinations (Gustafsson et al., 1982). Possible mechanisms include interaction with opioid receptors located in the thalamus, limbic system and cerebral cortex (Shulman et al., 1984). The effects can be inhibited by naloxone.

Several studies have investigated the cognitive effects of opioids after per os or iv. administration in healthy volunteers (Lawlor, 2002; Ersek et al., 2004). They have shown that while parenteral opioids are associated with significant dose-related cognitive impairment, oral opioids are associated only with insignificant and mild impairment (Ersek et al., 2004). Moulin has reported no decrease in cognitive scores of patients with non-malignant pain treated with strong opioids for the first time, and who had previously been given weak opioids (Moulin et al., 1996; Haythorntwaite et al., 1998), while Sjogren has studied 40 patients with chronic non-malignant pain and found significantly more cognitive and psychomotor impairment in those receiving long-term oral opioids compared with controls (Sjogren et al., 2000). 


\section{Neonatal morbidity}

Morphine is widely applied neuraxially in obstetric patients for pain relief during labor and Cesarean section. Pharmacokinetic features of opioids suggest that these drugs may be transferred across the placenta. Opioids have been detected in the neonatal blood following maternal administration of i.t. or epidural morphine (Nybell-Lindahl et al., 1981; Bonnardoth et al., 1982; Preston et al., 1988). Clinically important respiratory depression has developed in neonates following the administration of epidural morphine and epidural fentanyl (Nybell-Lyndahl et al., 1981). Capogna has reported cases when neurologic signs of drug-induced depression was detected in neonates (Capogna et al., 1989).

\section{Sexual dysfunction}

Some authors have reported that epidural administration of morphine may lead to sustained erection and inability to ejaculation (Rawal et al., 1983, Ruan et al., 2007). Erection is influenced by the parasympathetic nervous system, whereas ejaculation and the termination of erection are influenced by the sympathetic nervous system (Pybus et al., 1984). Therefore, sustained erection and inability to ejaculate may be secondary to an opioid-induced decrease in sympathetic nervous system response to sexual stimulation (Pybus et al., 1984). This effect was not detected after i.m. or iv. administration of drugs; thus, this side effect is related to the spinal cord (Torda et al., 1980; Wiesenfeld-Hallin and Södersten, 1984).

\section{Gastrointestinal dysfunction}

Systemic opioid administration is well known to cause altered GI motility, delayed gastric emptying, prolonged intestinal transit time, it may emerge constipation or ileus; however, these symptoms can be detected after i.t. administration of opioids, too (Porreca et al., 1983; Wattwil, 1988; Thordn et al., 1988). Anderson et al. have found that $30 \%$ of the patients in their study experienced constipation at least once over a 2year follow-up period in non-malignant pain (Anderson et al., 1999). These effects are not related to systemic absorption of opioids, and it appeared to be caused by interaction with opioid receptors located in the spinal cord (Thordn et al., 1988), and effectiveness of naloxone also supports it (Liu et al., 2002). 


\section{Fluid retention}

I.t. or epidural administration of opioids can lead to oliguria and water retention. The incidence of symptoms is between $6.1 \%$ (Winkelmuller et al., 1996) and 20.7\% (Aldrete and Couto de Silva, 2000) after long-term administration. Some studies have reported severe complications which produced lymphedema, ulcerations and hyperpigmentation of the skin. There are some predisposing factors, e.g., cardiovascular disease, deep venous thrombosis, peripheral vascular disease, and venous stasis of the lower extremities, after which the incidence of fluid retention is increased (Aldrete et al., 2000). The development of this side effect is explained by the release of vasopressin, stimulated by cephalad migration of opioids in CSF, and subsequent interaction with opioid receptors located in the posterior pituitary gland (Simatov et al., 1997, Ruan, 2007). The symptoms can be abolished by customary antiedema treatment (Harris and Kotob, 2006). The presence of the predisposing factors is a relative contraindication to the long-term i.t. infusion of opiates (Aldrete and Couto de Silva, 2000).

\section{Catheter tip granuloma}

Some experimental studies have confirmed that epidural or i.t. administration of morphine or any opioid derivatives may cause spinal cord necrosis and inflammatory changes, when it was employed in large doses in animal models (Rawal et al., 1991; Coombs et al., 1994). Intraspinal drug delivery (IDD) therapy has been used in patients with intractable pain syndromes, who failed to respond to conventional treatment or could not tolerate systemic opioid therapy. Spinal anesthetics can induce histopathologic lesions and regional hemodynamic alterations in the spinal cord (Malinowsky and Pinaud, 1996). In contrast, postmortem examination did not verify a lesion from patients after prolonged administration of morphine (Coombs et al., 1985). The mechanism by which opioids may exert their neurotoxic effects is complicated and involves several different pathways including endocytosis of opioid receptors (Mercandante et al., 2003), and the activation of NMDA receptors (Mao et al., 2002).

Inflammatory tissue mass consisting of granuloma tissue lesions at the tip of i.t. catheters has been reported by North (North et al., 1991). Several studies in large animal models have shown that the granuloma, arising from the meninges could cause direct spinal cord compression and symptoms (Langsam, 1999). The incidence of i.t. catheter tip inflammatory tissue mass depended on the duration of the application. In $0.4 \%$ of 
the cases, granulomas were detected after 2 years, and this value increased to $1.16 \%$ after 6 years of therapy (Yaksh et al., 2002). However, the incidence of asymptomatic lesions may be much higher (Toombs et al., 2005). Allen has confirmed that the formation of granulomas depend on the concentration, but not the dose of morphine (Allen et al., 2006). Therefore, the FDA approved preservative free i.t. morphine in concentration of $10-20 \mathrm{mg} / \mathrm{mL}$ (Follet, 2004). It has been reported that the addition of clonidine (specific a2-receptor agonist) in a dose higher than $250 \mathrm{mcg} / \mathrm{day}$ could prevent granuloma development in canine model (Yaksh et al, 2002). This granuloma can be detected well by computed tomography (CT) or MRI (McMillan, 2004). The cases with neural compression signs, progressive neuropathy or cauda equina syndrome require surgical intervention, but in asymptomatic cases, the termination of infusion or saline infusion usually results in spontaneous regression of the mass (McMillan, 2004).

\section{Endocannabinoid system}

Cannabis was also widely used to trait pain for many centuries, and interest in cannabis-based medicines has also emerged, recently.

The endocannabinoid system consists of the endogenous cannabinoids (endocannabinoids), cannabinoid receptors and the enzymes that synthesize and degrade endocannabinoids. Mammalian tissues express at least two cannabinoid receptor types, CB1 and CB2, both of which are members of the superfamily of GPCRs (Howlett, 2002). CB1 receptors were cloned in Tom Bonner's laboratory in 1990, (Matsuda et al., 1990), and three years later, CB2 receptors were cloned by Munro in 1993 (Munro et al., 1993).

\section{Localization of cannabinoid receptors}

CB1 receptors are expressed predominantly at central and peripheral nerve terminals, where they mediate inhibition of transmitter release. They occur in high density in many are as related to pain: in the PAG and in the RVM, in the superficial layers of the spinal $\mathrm{DH}$, and in the DRG, from which they are transported to both central and peripheral terminals of primary afferent neurons (Herkenham et al., 1991; Hohmann et al., 1998; Sanudo-Pena et al., 1999; Salio et al., 2002; Ständer et al., 2005). CB1 receptors have also been localized in various neurons of the GI tract (Izzo et al., 2001), in endothelial 
cells (Sugiura et al., 1998; Wagner et al., 1998; Golech et al., 2004). However, they are also found in non-neuronal cells and tissues, for example, in the pituitary gland, and immune cells (Herkenham et al., 1990; Tsou et al., 1998; Mackie, 2005).

CB2 receptors have initially been localized and are most highly expressed by immunocompetent cells (particularly those derived from macrophages, such as microglia, osteoclast and osteoblast) of the spleen, thymus, and various circulating immune cell populations (Lynn and Herkenham, 1994; Galiegue et al., 1995; Ofek et al., 2006), and different studies have confirmed the presence of them in both peripheral and CNS neurons (Pertwee et al., 1995; Ständer et al., 2005; Duncan et al., 2008). However, CB2 transcripts in the normal brain are present at much lower levels than CB1 transcripts. In contrast to the predominant presynaptic axon terminal location of CB1 receptors, $\mathrm{CB} 2$ receptors appear to localize in the cell bodies and dendrites of central (Gong et al., 2006) and peripheral neurons (Duncan et al., 2008).

\section{Signaling of cannabinoid receptors}

Both $\mathrm{CB} 1$ and $\mathrm{CB} 2$ receptors primarily signal through the $\mathrm{G}$ proteins ( $\mathrm{Gi}$ and $\mathrm{Go}$ ) (Howlett et al., 2002). These receptors inhibit adenylyl cyclase (Howlett, 1984), and activate mitogen-activated protein kinase by signaling through $\mathrm{G}_{\mathrm{i} / \mathrm{o}}$ proteins, leading to activation of A-type and inwardly rectifying potassium current (Deadwyler et al., 1995) and inhibition of N- and P/Q-type calcium current (Brown et al., 2004). Stimulation of CB2 receptors has similar consequences, but the modulation of ion channels is more variable (Howlett et al., 2002); thus, they do not inhibit the voltage-gated $\mathrm{Ca}^{2+}$ or activate the $\mathrm{K}^{+}$-channels (Felder et al., 1995), which may account for the lack of significant psychotropic effects upon administration of CB2R-selective agonists (Hanus et al., 1999; Malan et al., 2001). Several knockout studies have shown evidence that other alternative receptors may also exist at which anandamide can act (Di Marzo et al., 2000; Breivogel et al., 2001; Cravat et al., 2001). 


\section{Transient receptor potential channels}

The discovery of the transient receptor potential (TRP) channels was a significant step to understand the activation of sensory fibers. The TRP channel recuperates 6 transmembrane domains and one pore (Ramsey et al., 2006). It was originally isolated from Drosophila photoreceptors. In mammals, 6 subfamilies have been classified: TRPC (canonical), TPRV (vanilloid), TRPM (melastatin), TRPP (polycystin), TRPM (mucolipin), and TRPA (ankyrin). TRPV1 sensitive (capsaicin 8-methyl-N-vanillyl-6nonenamid, an active component of chili peppers) receptor was cloned (Caterina et al., 1997). TRPV1 has been revealed in different cell types, e.g., keratinocytes, pancreas $\beta$ cells, endothelial cells, lymphocytes, macrophages and in neurons.

TRPV1 is basically stimulated by endogenous ligands (endovanilloids). Schmelz has injected capsaicin intradermal in humans and detected different effect on mechanically sensitive and insensitive nociceptors. On the mechanically insensitive $\mathrm{C}$ nociceptor, mechanical and heat responsiveness have developed (Schmelz et al., 2000). TRPV1 channel has been activated by elevated temperatures and by protons at $\mathrm{pH}$ below 6.5 (Caterina et al., 1997). Several studies have revealed that to noxious heat $\left(>43{ }^{\circ} \mathrm{C}\right)$, oxidized metabolites of linoleic acid 9- and 13-hydroxyoctadecadionic acid have been realized, and this substance and the metabolites activated directly the TRPV1 (Patwardhan et al., 2010). These metabolites may also play a role in inflammation and hyperalgesia (De Petrocellis and Di Marzo, 2005; Patwardhan et al., 2009). Trevisani et al. have proved that the burning sensation caused by alcoholic tincture was due to the activation of TRPV1 (Trevisani et al., 2002).

TRP vanilloid 1, which is thought to function as an ionotropic cannabinoid receptor, and some deorphanised GPCRs: GPR18, GPR55, and GPR119 are expressed highly in nociceptors in inflammatory and neuropathic pain states (Tominaga and Caterina, 2004). Although some of the effects could be described to actions at CB2Rs or GPR55Rs, others may be due to activation of non-cannabinoid receptors or to receptorindependent interactions with membrane ion channels and intracellular secondmessenger systems (Oz et al., 2003, Oz et al., 2005).

Di Marzo has determined that anandamide has an affinity for the TRPV1 receptor in vitro but is 5-fold to 20-fold lower than its affinity for the CB1 receptor (Di Marzo et 
al., 2001). TRPV1 co-localizes with CB1 receptors in the DRG and spinal cord (Ahluwalia et al., 2003; Price et al., 2004) and brain (Cristino et al., 2006) and with CB2 receptors in sensory neurons (Anand et al., 2008). Although anandamide may be less potent as a TRPV1 agonist than as a CB1 receptor agonist, elevation of its endogenous levels with fatty acid amide hydrolase (FAAH) inhibitors [e.g., cyclohexylcarbamic acid 3'-carbamoyl-biphenyl-3-yl ester (URB597)] can lead to effects that are mediated by TRPV1 (Maione et al., 2006; Morgese et al., 2007; Rubino et al., 2008).

\section{Endocannabinoids}

After the discovery of cannabinoid receptors, the next step was the detection of endogenous ligands. Arachidonoyl ethanolamide (anandamide, AEA) was the first brain metabolite shown to act as a ligand of CB1 cannabinoid receptors (Devane et al., 1992) and then, it was followed by 2-arachidonoylgycerol (2-AG) extracted from the canine gut and later from the brain (Mechoulam et al., 1995; Stella et al., 1997). Later, more candidates have been proposed: as the anandamide analogs, dihomolinolenoylethanolamide, docosatetraenoylethanolamide, (13S,5Z,8Z,11Z,14Z)-13methyl-eicosa-5,8,11,14-tetraenoic acidN-(2-hy-droxyethyl)amide and 2-arachidonylglyceryl ether (noladin, 2-AGE), O-arachidonoyl-ethanolamine (virhodamine) further $\mathrm{N}$-arachidonoyl-dopamine (NADA) N -oleoyl dopamine, oleamide, RVD-hemopressin or pepcan ( $\alpha$-hemoglobin-derived dodecapeptide RVD-hemopressin) may also be endocannabinoids (Bisogno et al., 2000; Huang et al., 2002; Porter et al., 2002; Gomes et al., 2009; Papahatjis et al., 2010).

Anandamide is only one of a large family of related bioactive acyl ethanolamides (Tan et al., 2006). A feature that distinguishes endocannabinoids from many other neuromodulators is that they are not synthesized in advance and stored in vesicles. Rather, their precursors exist in cell membranes and are cleaved by specific enzymes (Alexander et al., 2007; Okamoto et al., 2007). AEA is mainly produced by a two-step enzymatic pathway involving calcium-dependent transacylase and phospholipase D from phosphatidylethanolamine (PE) derivative N-arachidonoyl PE (Sugiura et al., 1996; Cadas et al., 1997). AEA either diffuses (Glaser et al., 2003) or is actively transported into cells (Patricelli et al., 2001), but the molecular identity of a specific 
plasma membrane transport protein has not been found (Fowler, 2012) and is rapidly degraded by FAAH to arachidonic acid.

AEA binds to the $\mathrm{CB} 1$ receptor and evokes agonist activity. There is evidence that AEA also binds to the $\mathrm{CB} 2$ receptor, although it does not evoke CB2 receptor-mediated effects to a biologically significant degree (Devane et al., 1992; Felder et al., 1995; DiMarzo and Deutsch, 1998). However, anandamide activates other receptors as well, including the TRPV1, and some of its effects (like antinociception) may be at least partially due to TRPV1 activation (Zygmunt et al,. 1999; Hajos et al., 2001; Tognetto et al., 2001; Di Marzo et al., 2002; van der Stelt et al., 2004; van der Stelt et al., 2005; Oz, 2006; Horvath G et al., 2008;).

2-AG binds to cannabinoid receptors and exhibits cannabinomimetic effects (Mechoullam et al., 1995; Stella et al.1997). The concentrations of 2-AG is 170-fold higher in the brain than that of AEA. 2-AG is synthesized via the diacylglycerol lipase (DAGL)-mediated hydrolysis of diacylglycerol and metabolized primarily by monoacylglycerol lipase (MAGL) (Dinh et al., 2002). FAAH is mainly a postsynaptic enzyme, whereas MAGL is localized to presynaptic axon terminals, suggesting possible differences in the functional roles of AEA and 2-AG (Gulyas et al., 2004).

It is known that 2-AG is a full agonist at the CB1 receptor, albeit one with a relatively low binding affinity, and it has been suggested that it is the optimal known candidate as the natural ligand at the CB2 receptor (Sugiura et al., 2000), but there is no direct binding to the TRPV1 receptor (Mechoulam et al., 1995).

The antinociceptive action of cannabinoids has been investigated widely. Peripheral administration of anandamide inhibits and reverses thermal hyperalgesia induced by peripheral injection of the inflammatory substance carrageenan via an action at CB1 receptors (Richardson et al., 1998; Hargraeves et al., 1998). This effect has been attenuated by locally administered AEA via a CB1 receptor-mediated mechanism, although no CB2 receptor-mediated effects have been detected. Similar effects have been described for the hyperalgesia that is associated with capsaicin injection ( $\mathrm{Li}$ et al., 1999). Injection of low doses of anandamide into an area of inflammation in the paw produced by carageenan (Richardson et al., 1998) and peripheral nerve injury in rodents (Herzberg et al., 1997) have reduced the ensuring hyperalgesia. Peripheral 
administration of either the CB1-selective agonist anandamide or the CB2-selective agonist palmitylethanolamide reduces formalin-evoked pain behavior, and these inhibitory effects are blocked by $\mathrm{CB} 1$ and $\mathrm{CB} 2$ receptor antagonists, respectively (Richardson et al., 1998; Calignano et al., 1998). Several electrophysiological and behavioral studies demonstrate that spinally administered natural, synthetic and endogenous cannabinoids have reproducible antinociceptive (Hohmann and Herkenham, 1998; Drew et al., 2000) and antihyperalgesic effects in animal models of acute and inflammatory nociception (Richardson et al., 1998). Intracerebral microinjections of cannabinoid receptor agonists into different brain areas, involved in the descending pain inhibitory pathway (Lichtman et al., 1996; Martin et al., 1999) also produce antinociceptive effects. Furthermore, peripheral noxious stimulation has caused the release of anandamide in the PAG (Walker et al., 1999).

The antinociceptive doses of cannabinoids have frequently been accompanied by side effects, which limited the use for treatment of chronic pain states. Catalepsy, motor deficits, and hypothermia are among the effects observed after the administration of centrally acting cannabinoids (Dewey, 1986; Pertwee, 1988; Maccarrone and Wenger, 2005). At the same time, these side effects may be advantageous for treatment in different other disorders, including obesity, psychoses, stroke, multiple sclerosis, drug addiction and movement disorders (Basavarajappa and Hungund, 2005; Di Marzo and Petrocellis, 2006). Selective CB2 receptor agonist ligands may be beneficial in the treatment of inflammatory and neuropathic pain states (Guindon and Hohmann, 2008), myocardiac ischemia and atherosclerosis (Pacher et al., 2008), as well as in degenerative bone diseases, such as rheumatoid arthritis (Lunn et al., 2007).

One alternative strategy might be to develop selective $\mathrm{CB} 1$ receptor agonists that do not penetrate the blood-brain barrier, thereby decrease the side effects. Another option is to develop peripherally acting selective inhibitors of endocannabinoids metabolism to elevate the level of endocannabinoids, and so would increase the activation of both CB1 and CB2 receptors. Kathuria has described a class of potent, selective and systemically active inhibitors of FAAH and affirmed potent effects in neuropathic pain symptoms (Kathuria et al., 2003). Inhibitors of MAGL have also been developed (Ghafouri et al., 2004). One of the noteworthy features of these inhibitors is brain impermeability 
(Gafouri et al., 2004; Karbarz et al., 2009); after all, they do not exhibit the adverse side effects of central CB1 receptor activation (Esfandyari et al., 2007).

It is supposed that the local application of endogenous ligands or their derivatives acting in a different receptors may provide effective antinociception without unbeneficial side effects.

\section{Hemopressin (HP)}

HP, a nonapeptide (H-Pro-Val-Asn-Phe-Lys-Leu-Leu-Ser-His-OH), is a product of the hemoglobin $\alpha$ chain, discovered in rat brain, and so named because it can cause small decreases in blood pressure (Rioli et. al., 2003; Lippton et al., 2006). A number of in vitro studies show that HP acts as a CB1 receptor inverse agonist, and it can act on both peripheral and central pain pathways in vivo ( Heimann et al. 2007; Dodd et al., 2010). These studies showed that HP pretreatment caused antinociceptive effects at systemic, local and spinal levels. The authors proposed that after CB1 blockade by the inverse agonist HP, the released endocannabinoids might induce antinociception by interfering with other pain transmission mechanisms (Heimann et al., 2007).

\section{Aims of the study}

- The aim of the study was to investigate the antiallodynic effects of the new EM-2 derivatives at spinal level, in a chronic pain model (EMD1-4; Table 1).

- The dose-depend effect of novel EM2 ligands compared with morphine as a gold standard in joint inflammation model at spinal level was to be studied.

- The antinociceptive potency of anandamide and 2 AG, applied intrathecally in joint inflammation model was to be characterized.

- The effects of hemopressin on the mechanical pain threshold in a joint inflammation model at spinal level was to be determined. 
- The influence of the intrathecal administration of synthetic CB1 and CB2 antagonists and hemopressin on the effects of $2-\mathrm{AG}$ was to be described.

\section{Materials and Methods}

\section{Animal experiments}

After institutional ethical approval had been obtained (Institutional Animal Care Committee of the Faculty of Medicine at the University of Szeged), in the first case, male Wistar rats (Charles River strain, Bioplan, Budapest, Hungary; 334 \pm 3.8 g; n=714/group), and in the second case, male Wistar rats (232 $\pm 2.0 \mathrm{~g})$ were used and housed in groups of 5-6 per cage, with free access to food and water, and with a natural light/dark cycle. Animal suffering and the number of animals per group were kept at a minimum.

\section{Drugs}

The following drugs were purchased: ketamine hydrochloride (Calypsol, Richter Gedeon RT, Budapest, Hungary), xylazine hydrochloride (Rompun, Bayer, Leverkusen, Germany), Gentamycin (Sanofi-Aventis, Budapest, Hungary), monosodium iodoacetate (MIA), $\lambda$-carrageenan, anandamide (Sigma-Aldrich Ltd. Budapest, Hungary) and morphine hydrochloride (Hungaropharma, Budapest, Hungary). EM-2 and its derivatives (Table 1) and hemopressin were synthesized by the Institute of Biochemistry, Biological Research Center, Hungarian Academy of Sciences, Szeged, Hungary).

2-AG and AM 251 (CB1 receptor antagonist; Tocris Bioscience, Bristol, UK). SSR144528-2 (SSR, CB2 receptor antagonist) was a generous gift from Sanofi Avensis, France).

In the first case, all substances were dissolved in saline. In the second case, anandamide and 2-AG were dissolved in ethanol: Tween $=2: 1$, respectively. Stock solutions were diluted with saline to a final ethanol concentration of 10\%. AM 251 and SSR were dissolved in dimethylsulfoxide (DMSO; Sigma-Aldrich, Ltd., Budapest, Hungary) and ethanol, and it was further diluted with distilled water. The concentration of DMSO and ethanol was $15 \%$ and 9 , respectively. I.t. administered drugs were injected over $120 \mathrm{~s}$ in a volume of $10 \mu \mathrm{L}$, followed by a $10 \mu \mathrm{L}$ flush of physiological saline. I.t. 
administrated drugs were injected over $120 \mathrm{~s}$ in a volume of $10 \mu \mathrm{L}$ flush of physiological saline.

\section{Experiments}

\section{Intrathecal catheterization}

The animal surgery and testing procedures were approved by the Institutional Animal Care Committee of the University of Szeged, Faculty of Medicine.

Rats were anesthetized with a mixture of ketamine hydrochloride and xylazine (72 and $8 \mathrm{mg} / \mathrm{kg}$ i.p., respectively). An i.t. catheter (PE-10 tubing; Intramedic, Clay Adams; Becton Dickinson; Parsippany, NJ; I.D. $0.28 \mathrm{~mm}$; O.D. $0.61 \mathrm{~mm}$ ) was inserted via the cisterna magna and passed $8.5 \mathrm{~cm}$ caudally into the subarachnoid space (Yaks and Rudy, 1976), which served to place the catheter tip between the T12 and L2 vertebrae, corresponding to the spinal segments that innervate the hindpaws (Dobos et al., 2003). After surgery, rats were housed individually and had free access to food and water. Animals exhibiting postoperative neurologic deficits (about $10 \%$ ), and also those that did not show paralysis of one of the hindpaws after the administration of $100 \mu \mathrm{g}$ lidocaine (about $0.5 \%$ ) were excluded (Dobos et al., 2003). The rats were allowed to recover for at least four days before testing, and were assigned randomly to the treatment groups. The observer was blind to the treatment administered. Repeated i.t. injections in the same animals were separated by 5-7 days. 
Table 1. The applied drugs and doses, the number of the animals in each group, in vitro characteristics an in vivo potency

\begin{tabular}{|c|c|c|c|c|c|c|c|c|c|c|}
\hline & 0 & $\frac{e s(1}{\underline{0}}$ & 1 & $\mathrm{nt}$ & ber & $\begin{array}{c}\mathrm{KI} \\
\mathrm{nM} \\
\mathrm{M} \\
\mathrm{OR}\end{array}$ & $\begin{array}{r}\text { EC50 } \\
(\mathrm{nM})\end{array}$ & $\begin{array}{c}\operatorname{Emax} \\
(\%)\end{array}$ & $\begin{array}{l}\text { Half- } \\
\text { life }\end{array}$ & $\begin{array}{l}\mathrm{ED} 25(\mathrm{CI}) \\
(\mu \mathrm{g})\end{array}$ \\
\hline Saline & 8 & & & & & & & & & \\
\hline $\begin{array}{l}\text { EM-2: Tyr-Pro- } \\
\text { Phe-Phe-NH2 }\end{array}$ & & 8 & & 8 & 9 & $\begin{array}{c}1.3 \\
5\end{array}$ & 212 & 163 & $\begin{array}{l}5.7 \\
\min \end{array}$ & $\begin{array}{l}6.3 \\
{[1.30-} \\
10.00]\end{array}$ \\
\hline $\begin{array}{l}\text { EMD1: Tyr- } \\
(1 \mathrm{~S}, 2 \mathrm{R}) \text { Ache- } \\
\text { Phe-pFPhe-NH2 }\end{array}$ & & 10 & & 9 & 10 & 1.5 & 92 & 168 & & $\begin{array}{l}5.3 \\
{[1.73-} \\
8.85]\end{array}$ \\
\hline $\begin{array}{l}\text { EMD2: Tyr- } \\
\text { (1S,2R)Ache- } \\
\text { Phe- } \\
\text { (2S,3S)bMePhe- } \\
\text { NH2 }\end{array}$ & & 10 & & 10 & 10 & $\begin{array}{c}0.8 \\
2\end{array}$ & 273 & 173 & & $\begin{array}{r}7.2 \\
\\
{[2.95-} \\
10.00]\end{array}$ \\
\hline $\begin{array}{l}\text { EMD3: Dmt- } \\
\text { (1S,2R)Ache- } \\
\text { Phe-pFPhe-NH2 }\end{array}$ & & 10 & 9 & 14 & & $\begin{array}{c}0.1 \\
3\end{array}$ & 51 & 176 & $>20 \mathrm{~h}$ & $\begin{array}{l}1.6 \\
{[1.02-} \\
2.11]\end{array}$ \\
\hline $\begin{array}{l}\text { EMD4: Dmt- } \\
\text { (1S,2R)Ache- } \\
\text { Phe- } \\
\text { (2S,3S)bMePhe- } \\
\text { NH2 }\end{array}$ & & 10 & & 10 & 8 & $\begin{array}{c}0.4 \\
7\end{array}$ & 17 & 159 & $>20 \mathrm{~h}$ & $\begin{array}{r}2.6 \\
\\
{[0.31-} \\
4.81]\end{array}$ \\
\hline Morphine & & & & & 9 & & & & & \\
\hline
\end{tabular}

Abbreviations: Ki MOR: The inhibitory constants (Ki) on MOR. EC 50 : potency of ligands on $[35 \mathrm{~S}] \mathrm{GTP} \gamma \mathrm{S}$ functional assay. $\mathrm{E}_{\max }$ : Efficacy of ligands on $[35 \mathrm{~S}] \mathrm{GTP} \gamma \mathrm{S}$ functional assay. Half-life: half-life of ligands in a crude rat brain membrane 
homogenate. $\mathrm{ED}_{25}: 25 \%$ effective dose after i.t. administration. CI: confidence interval. The in vitro data are from Mallareddy et al., 2011.

\section{Induction of inflammation}

\section{Series 1}

Osteoarthritis was induced by injecting MIA $(1 \mathrm{mg} / 30 \mu \mathrm{L})$ into the tibiotarsal joint of the right hindleg on two consecutive days.

\section{Series 2}

The inflammation was elicited by injecting carrageenan (carrageenan is a family of linear sulphated polysaccharides that are extracted from red edible seaweeds) (300 $\mu \mathrm{g} / 30 \mu \mathrm{L}$ ) into one of the tibiotarsal joints (on the paralyzed side during lidocaine administration) (Dobos et al., 2003; Mecs et al., 2009).

Both treatments were given to gently restrained conscious animals, using a 27-gauge needle, without anesthesia so as to exclude any drug interaction. These injections did not elicit signs of major distress. Animals were allowed to recover for 14 days after MIA, which had consistently been shown to cause severe end-stage cartilage destruction resulting in osteoarthritis-like joint pain (Steinmeyer et al., 1997; Bove et al., 2003). Carrageenan induced allodynia peaked at $2-3 \mathrm{~h}$ after the injection.

In both experiments, to determine the changes in the size of the inflamed joint, the anteroposterior and mediolateral diameters of the paw were measured at the level of the ankle joint with a digital caliper. The cross section area was calculated with the formula $a \times b \times \pi$, where $a$ and $b$ signify the radius in the two aspects.

\section{Behavioral nociceptive testing}

The threshold for withdrawal from mechanical stimulation to the plantar aspect of the hindpaws was assessed using a dynamic plantar aesthesiometer (Ugo Basile, Comerio, Italy), which consists of an elevated wire mesh platform to allow access to the ventral surface of the hindpaws. Prior to baseline testing, each rat was habituated to a testing box with a wire-mesh grid floor for at least $20 \mathrm{~min}$. 
Measurements were done with a straight metal needle (diameter $0.5 \mathrm{~mm}$ ) that exerts an increasing upward force at a constant rate $(4.25 \mathrm{~g} / \mathrm{s})$ with a maximum cut-off force of 50 g over an $8 \mathrm{~s}$ period. The measurement was stopped when the paw was withdrawn, and the results were expressed as PWD thresholds in grams.

\section{Experimental protocols}

\section{Series 1}

After baseline determination of the tibiotarsal joint diameter and mechanical paw withdrawal (PWD) threshold (pre-MIA baseline values on Day 1), MIA was injected. These measurements were repeated 7 and 14 days later, and then, the i.t. catheterization was performed. One week later, the non-paralyzed rats were selected, and after the postMIA baseline value determination, the different ligands were administered (Table 1).

The control group received physiological saline. In the positive control group, animals were treated with $10 \mu \mathrm{g}$ morphine. The pain thresholds were registered 10, 20, 30, 45, $60,70,90$ and 120 min after the i.t. injection. The mean of the values obtained between 10-30, 45-70 and 90-120 min were analyzed.

\section{Series 2}

After baseline determination of the joint diameter and mechanical PWD threshold (precarrageenan baseline value at $-180 \mathrm{~min})$, carrageenan was injected. These measurements were carried out again 3 hours after carrageenan injection (postcarrageenan baseline values at $0 \mathrm{~min}$ ). After post-carrageenan baseline determination, $\operatorname{HP}(0.3,1,3,10,30 \mu \mathrm{g}), 2-\mathrm{AG}(1,10,100,200 \mu \mathrm{g})$ or anandamide $(10,30,100,200$ $\mu \mathrm{g})$ was given i.t. and mechanical sensitivity was defined at 10, 20, 30, 45, 60, 75, 90 and 105 min post-administration. The control group received physiological saline (vehicle of HP) or vehicle of 2-AG/anandamide.

Since vehicle-treated groups did not differ from the saline-treated one, we merged the data of these animals. To determine the involvement of $\mathrm{CB} 1$ and $\mathrm{CB} 2$ receptors in the effects of 2-AG, separate groups of animals were pretreated with AM 251 (antagonist of CB1 receptors, $10 \mu \mathrm{g}$ ) or SSR (antagonist of CB2 receptors, $15 \mu \mathrm{g}$ ) $20 \mathrm{~min}$ before $200 \mu \mathrm{g} 2-\mathrm{AG}$ injection. The control group was injected with vehicles of 2-AG and CB- 
antagonists. To investigate the potential antagonistic effects of HP on the 2-AG induced antinociception, we co-administered 3 or $30 \mu \mathrm{g}$ HP with $200 \mu \mathrm{g}$ 2-AG.

At the end of the experiment, the joint diameters were measured again.

We did not examine the motor behavior systematically, nor did we quantify it, but the animals' behavior was observed, and in most animals there were no signs of altered behavior (immobility, flaccidity, excitation or motor weakness). However, the administration of $10 \mu \mathrm{g}$ EMD3 produced paralysis, and 100 or $200 \mu \mathrm{g}$ doses of anandamide caused temporary (during the injection) vocalization and excitation, suggesting a pain-inducing potential of anandamide (Horvath et al., 2008; Tuboly et al., 2009).

\section{Statistical analysis}

Data are presented as means \pm SEM. Data sets were examined by one way or repeated measures of ANOVA. Post hoc comparisons were carried out with the Fisher LSD test. A $\mathrm{p}$ value lower than 0.05 was considered significant. Data analyses were performed with the STATISTICA (Statistica Inc., Tulsa, Oklahoma, USA) software.

In the first series, the PWD thresholds on the inflamed side were transformed to \% maximum possible effect (\%MPE) by the following formula: \%MPE $=$ (observed threshold - post-MIA baseline threshold $) /(50$ - post-MIA baseline threshold $) \times 100$. Therefore, $100 \%$ MPE means perfect relief of allodynia (equivalent to cut-off value [50 g] for all measurements), while $0 \%$ MPE means that the observed threshold is equivalent to the post-MIA baseline value. Area under the curve (AUC) values were obtained by calculating the area between 0 and $120 \mathrm{~min}$ to construct dose response curves for different doses of endomorphine ligands. AUC $5500\left(\mathrm{AUC}_{\max }\right)$ value would mean complete relief of hyperalgesia $(50 \mathrm{~g})$ during the whole period. We observed almost no effect regarding the AUC values after saline treatment $\left(\mathrm{AUC}_{\min }=2813 \pm\right.$ 227). The mean AUC values were used for linear regression analysis (least square method) to determine the $\mathrm{ED}_{25}$ values with $95 \%$ confidence intervals (CI). The $25 \%$ effective dose $\left(\mathrm{ED}_{25}\right)$ means the dose that yielded $25 \%$ increase in the PWD latency for the whole period (3485). 


\section{Results}

\section{Joint edema}

\section{Series 1}

MIA injection caused permanent but moderate increase in joint cross-section area compared with the contralateral side $\left(48.4 \pm 0.37\right.$ vs $\left.38.3 \pm 0.15 \mathrm{~mm}^{2}, \mathrm{p}<0.01\right)$.

\section{Series 2}

3 hours after the injection of carrageenan into the ankle, there was significant $(p<0.01)$ increase in joint cross-section area compared with pre-injection control levels (from $36 \pm 0.1 \mathrm{~mm}^{2}$ to $73 \pm 0.5 \mathrm{~mm}^{2}$ ).

These conspicuous increases in joint sizes were the result of edema formation, confirming that the MIA and carrageenan treatment resulted in an inflammatory reaction (Bar-Yehudaet al., 2009). None of the treatments influenced the degree of edema; the cross section of the ankle was $49.5 \pm 0.53 \mathrm{~mm}^{2}$ at the end of the first experiments, and in the second series, it was $72 \pm 0.5 \mathrm{~mm}^{2}$, which did not differ from the post-MIA and post-carrageenan baseline values.

\section{Mechanosensitivity}

\section{Series 1}

Basal PWD threshold was $41 \pm 0.6 \mathrm{~g}$, and MIA caused significant decrease in PWD threshold on the injected side. This threshold was lowest 1 week after MIA (15 $\pm 0.6 \mathrm{~g})$, and later it stabilized at $24 \pm 0.5 \mathrm{~g}$.

MIA did not have significant influence on the non-inflamed side $(43 \pm 0.5 \mathrm{~g})$. None of the treatments changed the mechanosensitivity on the non-inflamed side; therefore, results were analyzed only on the inflamed paws.

All the drugs had antinociceptive potency; therefore, we compared the effects of different doses of the analogues with parent EM-2. As for the lowest dose $(0.3 \mu \mathrm{g})$, ANOVA with repeated measurements showed significant effects of time $\left(\mathrm{F}_{2,104}=9.6\right.$, $\mathrm{p}<0.001)$ and interaction $\left(\mathrm{F}_{10,104}=2.4, \mathrm{p}<0.05\right)$. The post hoc comparison revealed that 
EMD3 and EMD4 produced significant antinociception, while EM-2 and the other two ands were ineffective in this dose (Figure A).

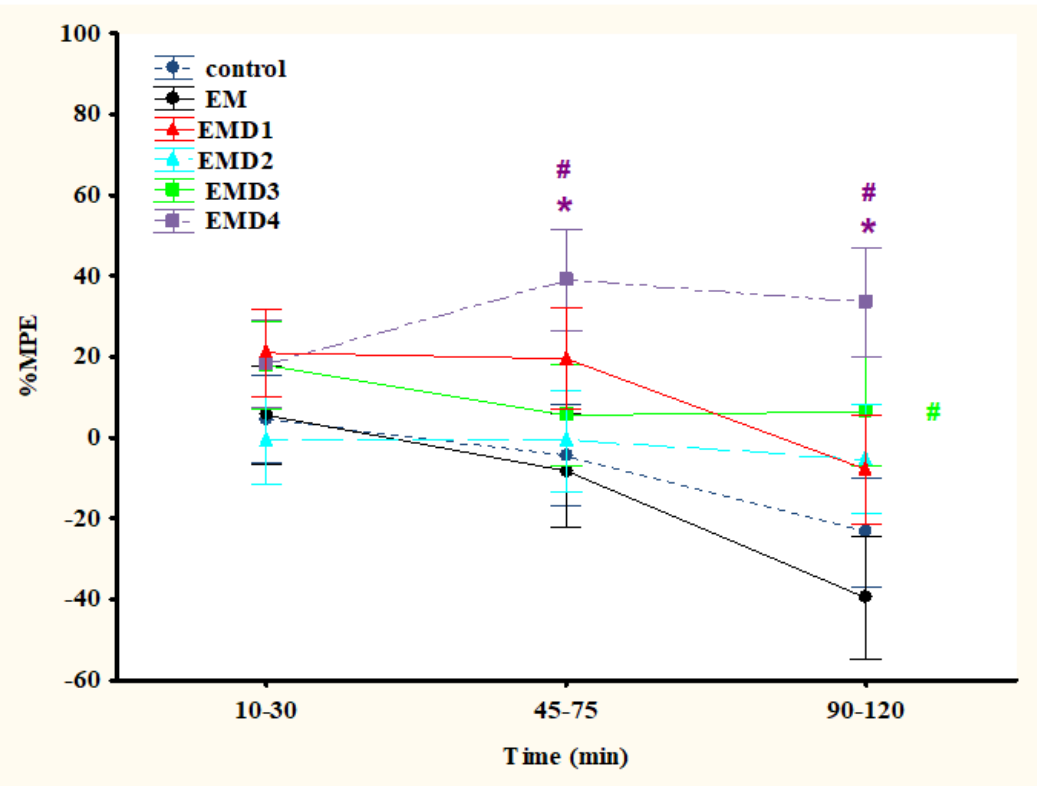

Figure A.

Figure A. Time-course effects of EM2 and the derivatives at $0.3 \mu \mathrm{g}$ dose. Each point signifies the mean \pm SEM of the results. * indicates a significant $(\mathrm{p}<0.05)$ difference as compared with the saline-treated group. \# denotes a significant difference as compared with the EM-2-treated group.

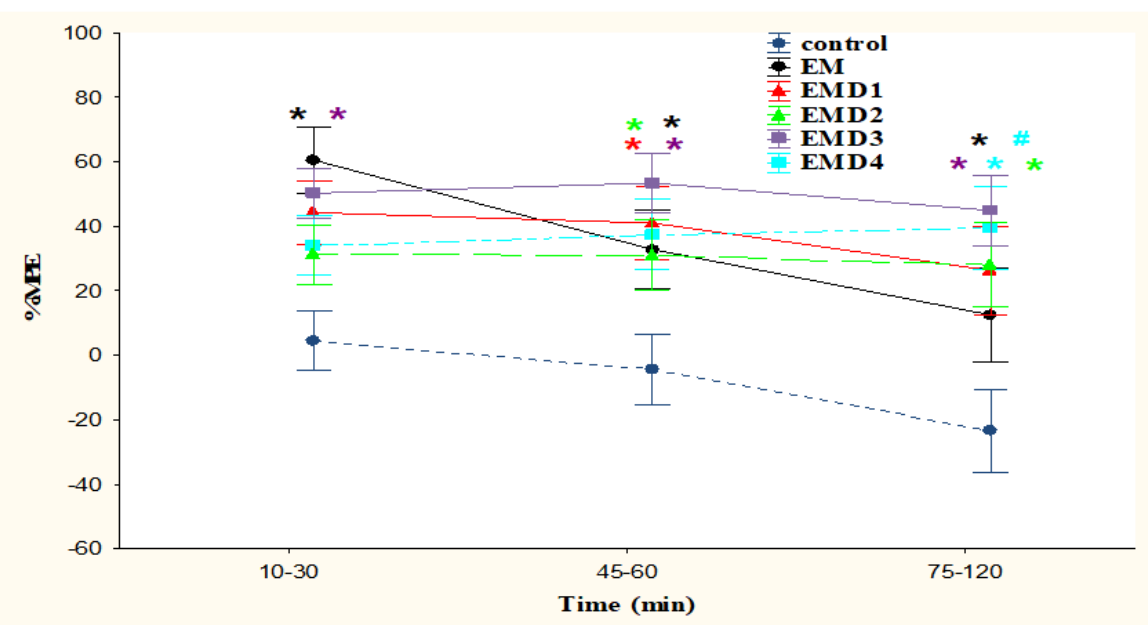

Figure B.

Figure B. Time-course effects of EM2 and the derivatives at $3 \mu \mathrm{g}$ dose. Each point signifies the mean \pm SEM of the results. $*$ indicates a significant $(\mathrm{p}<0.05)$ difference as compared with the saline-treated group. \# denotes a significant difference as compared with the EM-2-treated group. 
At $3 \mu \mathrm{g}$, all of the ligands produced antiallodynia. ANOVA with repeated measurements showed significant effects of treatment $\left(\mathrm{F}_{5,55}=5.4, \mathrm{p}<0.001\right)$ and time $\left(F_{2,110}=5.6, p<0.01\right)$. Post hoc comparison showed that EMD3 was more effective than EM-2 during the last investigated interval (75-120 min) (Figure B).

Regarding the highest dose $(10 \mu \mathrm{g})$, EMD3 caused prolonged paralysis of the animals; therefore, we could not analyze their data on the pain test. ANOVA with repeated measurements showed significant effects of treatment $\left(\mathrm{F}_{5,50}=8.4, \mathrm{p}<0.001\right)$ and time $\left(F_{2,100}=19.8, p<0.001\right)$. Post hoc comparison showed that all the drugs were effective compared to the control group at the first and second investigation period; however, EMD4 was effective during the whole period compared to both control and EM-2 treated groups. Morphine, as a positive control, produced long-lasting and highly effective antinociception. EM-2, EMD1 and EMD2 were as effective as morphine only in the first investigated period (10-30 min), while the effect of EMD4 did not differ significantly from morphine during the whole period (Figure C).

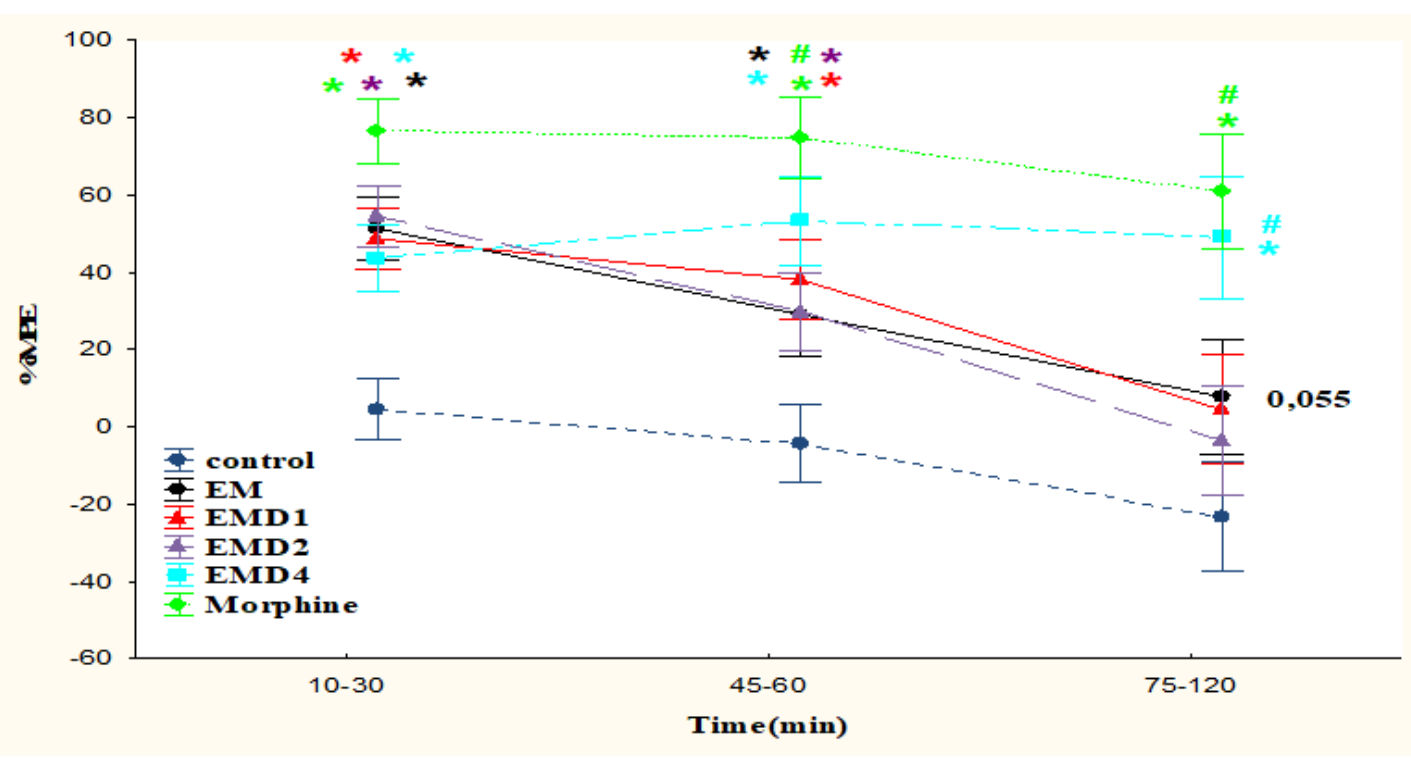

Figure C.

Figure C. Time-course effects of EM2, morphine and the derivatives at $10 \mu \mathrm{g}$ dose. Each point signifies the mean \pm SEM of the results. * indicates a significant $(p<0.05)$ difference as compared with the saline-treated group. \# denotes a significant difference as compared with the EM-2-treated group. 


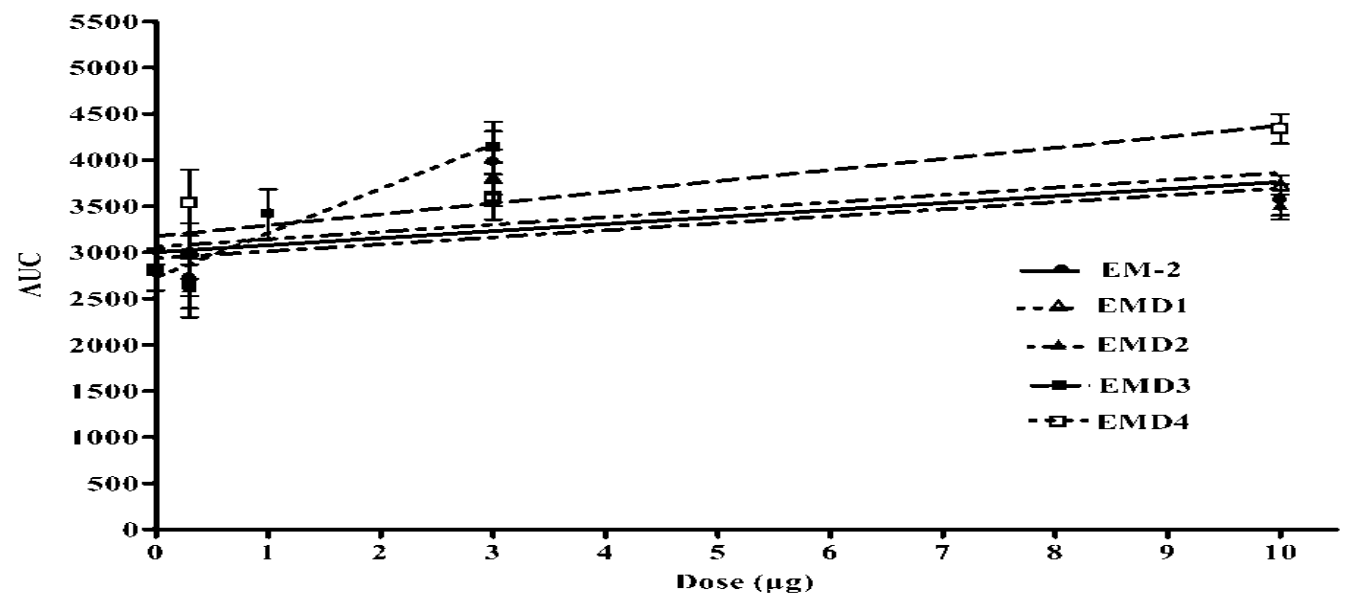

Figure D.

Figure D. The dose-dependent effects of EM and derivatives (AUC values between 0 and $120 \mathrm{~min}$ ).

As for the dose-response curves of the ligands, we observed that in the case of EMD3 the steepness of the curve was higher, and the curve of EMD4 was also slightly leftshifted (Figure D). However, $\mathrm{ED}_{25}$ values did not reveal a significant difference between these ligands (Table 1).

\section{Series 2}

The basal mechanical PWD threshold was $45 \pm 0.4 \mathrm{~g}$, and carrageenan caused significant decrease in PWD threshold on the inflamed side $(10 \pm 0.3 \mathrm{~g})$, but it did not have a significant influence on the non-inflamed side. None of the treatments changed the mechanosensitivity on the normal side; therefore, results were analyzed only on the inflamed paws.

Neither did HP cause significant antiallodynic effect compared to the control group, nor were any motor impairments observed in this wide dose-range $(0.3-30 \mu \mathrm{g})$ (Figure E). 


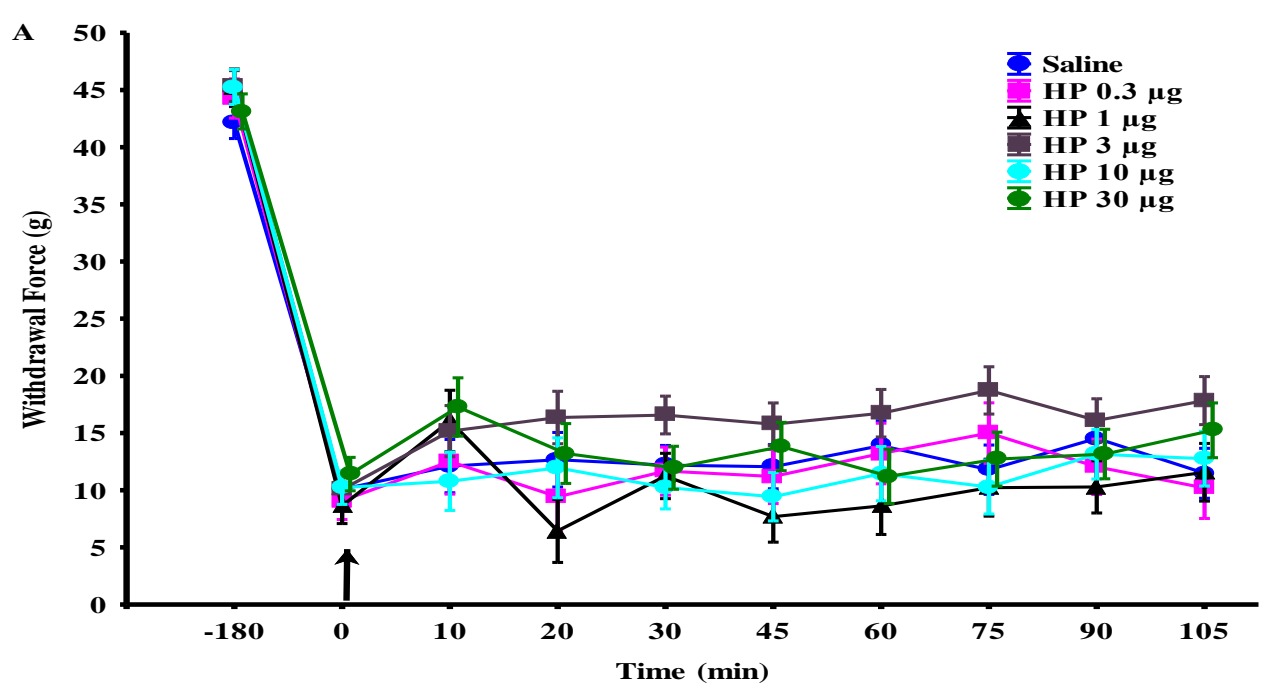

Figure E.

Figure E. Time-course and dose-dependent effects of hemopressin (HP) on the inflamed side. Each point signifies the mean \pm SEM of the results.

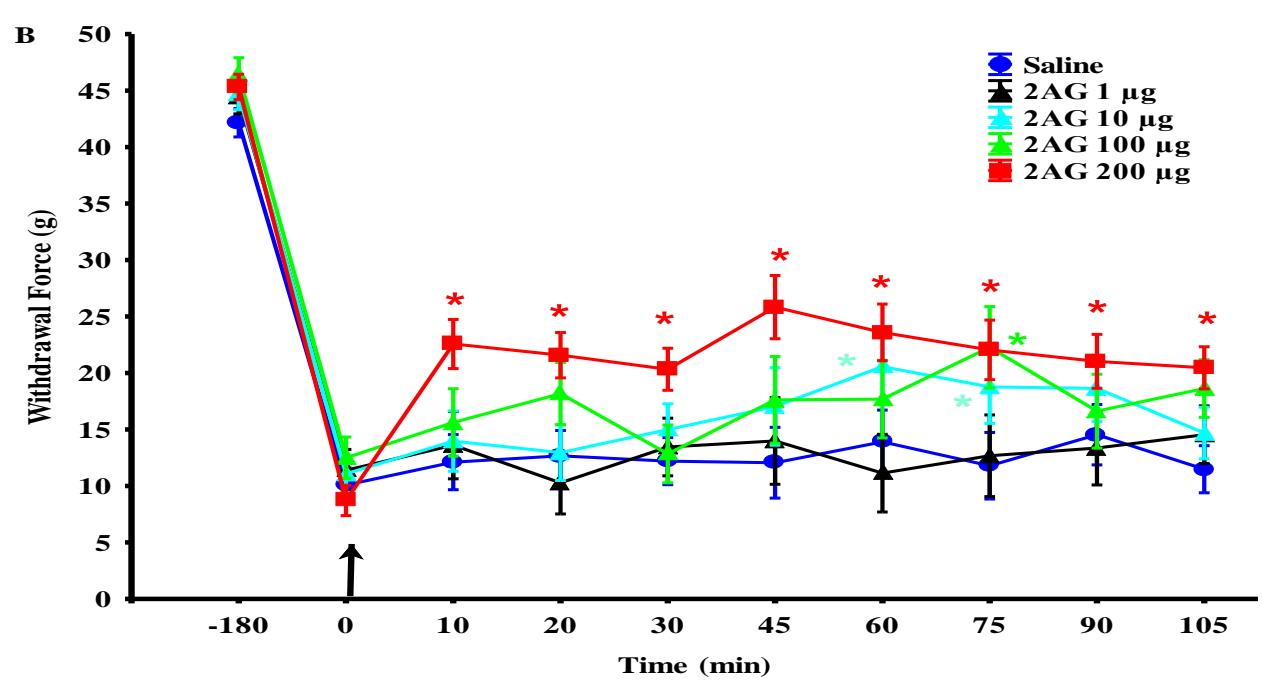

Figure F.

Figure F. Time-course and dose-dependent effects of 2-arachidonoyl-glycerol (2-AG) on the inflamed side.

2-AG by itself produced a dose-dependent antiallodynic effect, which developed gradually, and it reached a maximum between 45 and 60 min (Figure F). ANOVA with repeated measures showed significant effects of treatment $\left(\mathrm{F}_{4,48}=4.7, \mathrm{p}<0.005\right)$ and time $\left(\mathrm{F}_{9,432}=94.3, \mathrm{p}<0.001\right)$. Thus, $1 \mu \mathrm{g} 2-\mathrm{AG}$ was ineffective, while $200 \mu \mathrm{g}$ caused a prolonged antinociceptive effect. 
Anandamide elicited a dose-dependent antinociceptive effect, which reached a maximum approximately at 20 min post-administration (Figure G). ANOVA with repeated measures showed significant effects of treatment $\left(\mathrm{F}_{4,47}=5.2, \mathrm{p}<0.005\right)$, time $\left(\mathrm{F}_{9,423}=68.5, \mathrm{p}<0.001\right)$, and interaction $\left(\mathrm{F}_{36,423}=1.9, \mathrm{p}<0.005\right)$. Thus, $10 \mu \mathrm{g}$ anandamide was ineffective, while $200 \mu \mathrm{g}$ caused a prolonged effect.

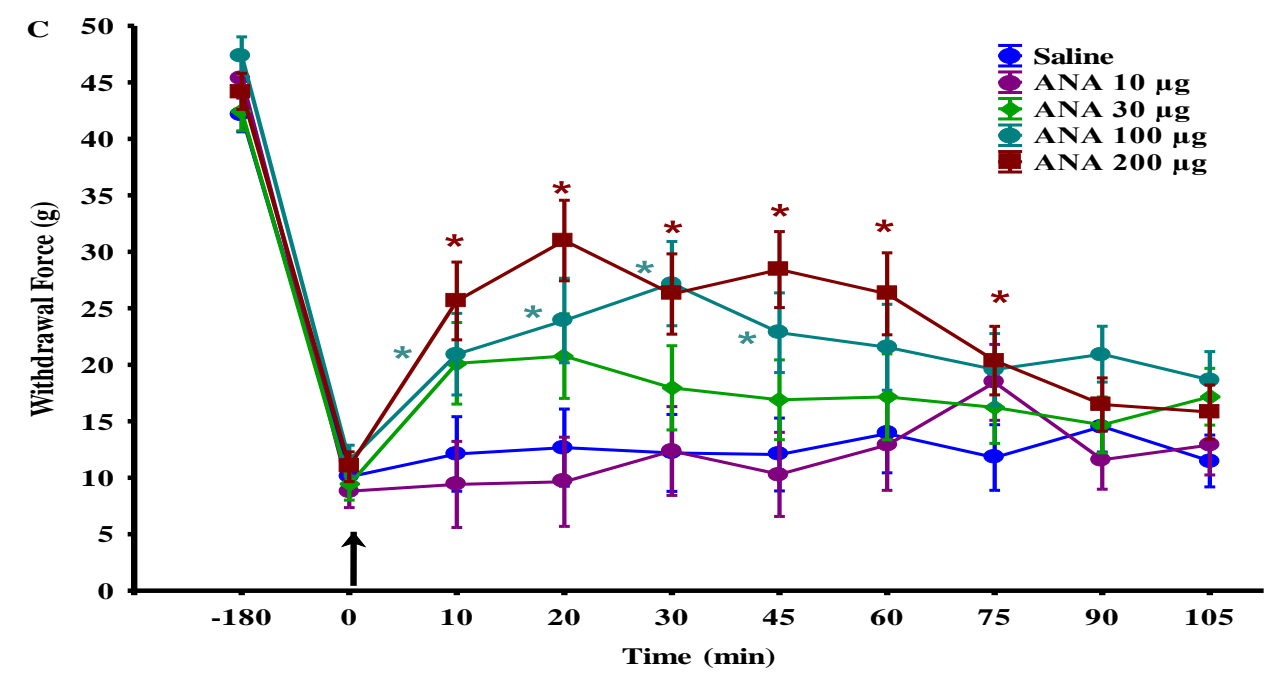

Figure G.

Figure G. Time-course and dose-dependent effects of anandamide on the inflamed side.

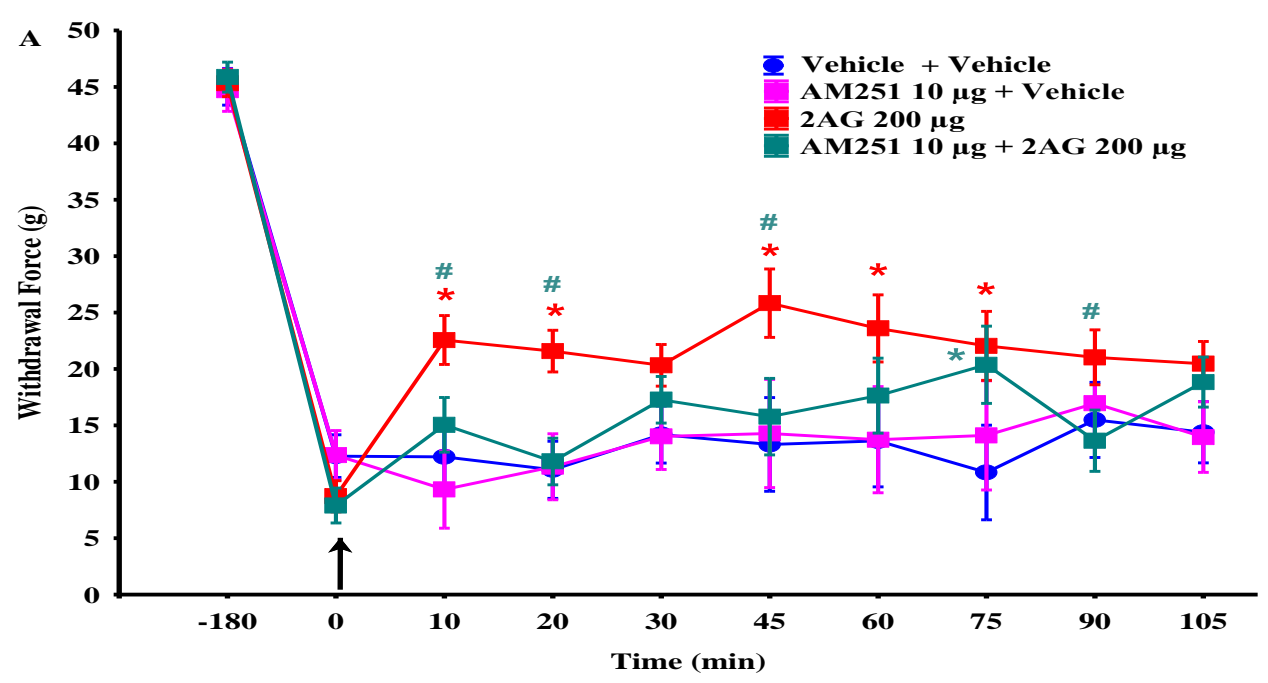

Figure $\mathrm{H}$.

Figure H. Time-course and effects of AM 251, 2-AG and AM2 51 pretreatment.

Regarding the effects of antagonists AM 251 and SSR at CB1 and CB2 receptors, respectively, none of the substances influenced the pain threshold in themselves 
(Figures $\mathrm{H}$ and I). AM 251 pretreatment antagonized the antiallodynic effect of 2-AG $(200 \mu \mathrm{g})$, while SSR did not influence it (Figures H and I).

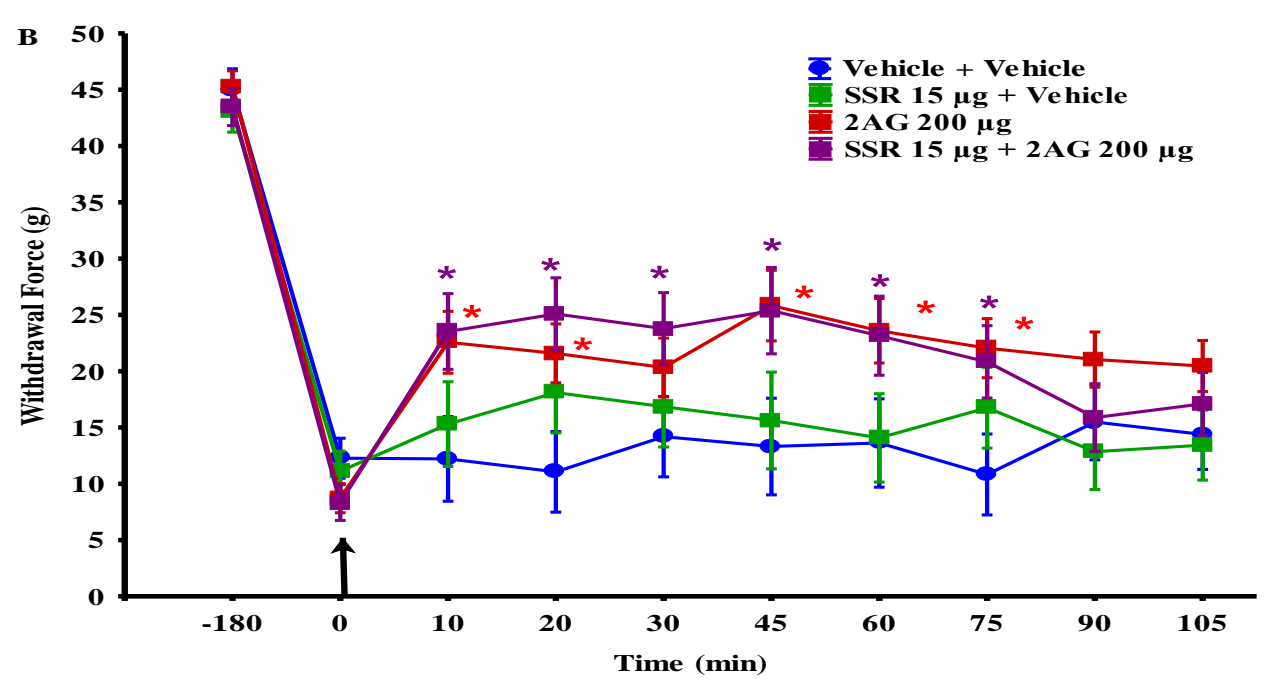

Figure I.

Figure I. Time-course and effects of SSR, 2-AG and SSR pretreatment.

Co-treatment of $3 \mu \mathrm{g}$ or $30 \mu \mathrm{g}$ HP with $200 \mu \mathrm{g}$ 2-AG significantly decreased the antinociceptive effect of 2-AG (Figures J and K).

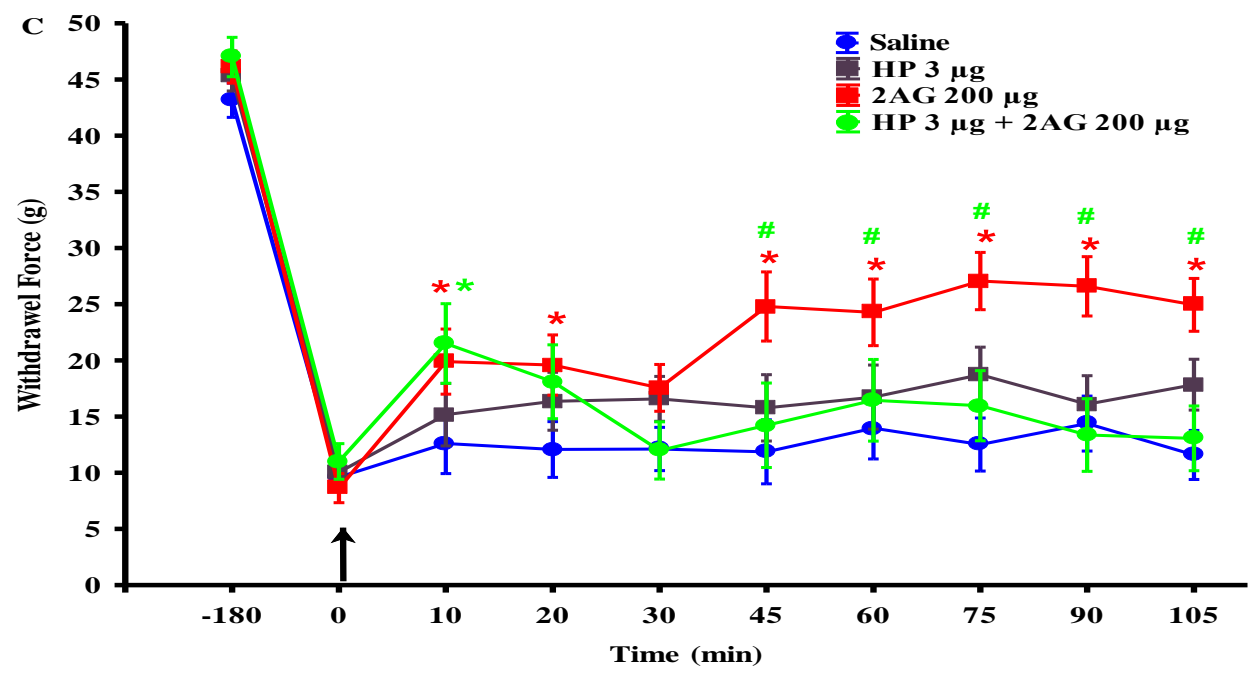

Figure J.

Figure J. Time-course and effect of HP $3 \mu \mathrm{g}, 2-\mathrm{AG} 200 \mu \mathrm{g}$ and 2-AG $200 \mu \mathrm{g}$ pretreatment. 


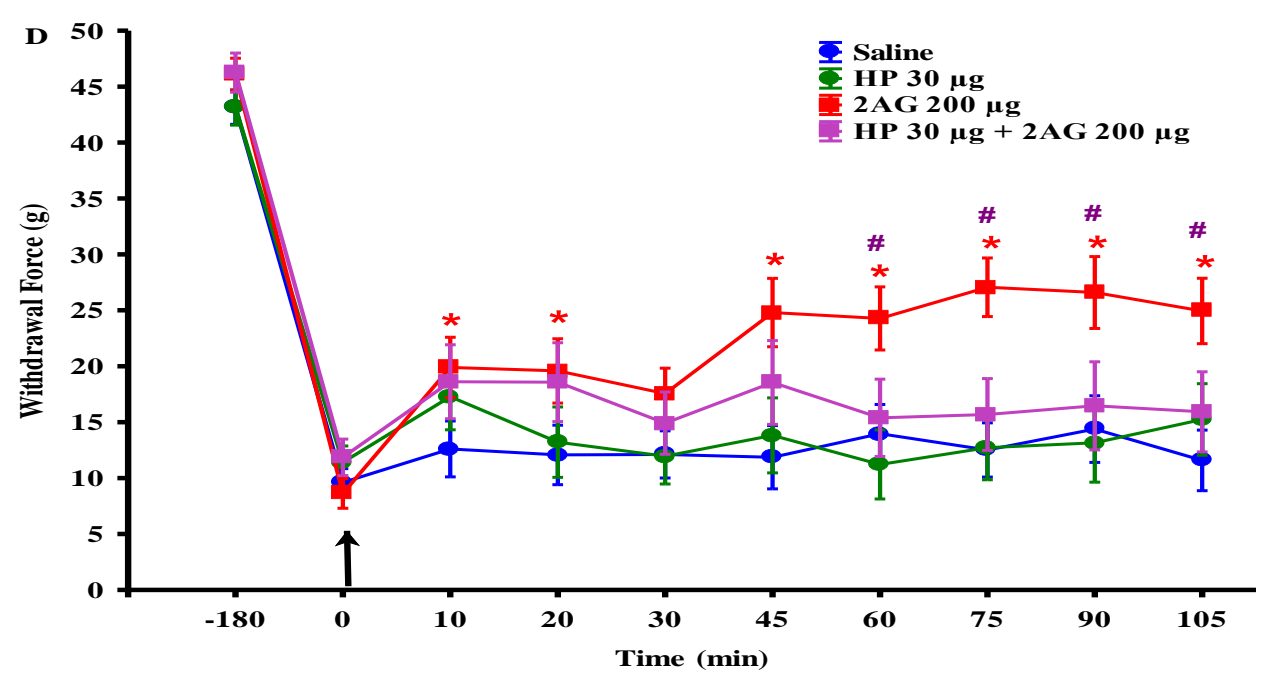

Figure K.

Figure K. Time-course and effects of HP $30 \mu \mathrm{g}, 2-\mathrm{AG} 200 \mu \mathrm{g}$ and 2-AG $200 \mu \mathrm{g}$ pretreatment.

\section{Discussion}

\section{Series 1}

Methylated amino acids have been used to modify the conformational mobility of the side chains (Hruby et al., 1997). An earlier study has shown that replacement of $\mathrm{Tyr}^{1}$ by Dmt resulted in marked increases in receptor-binding affinity and bioactivity in numerous opioid peptide agonists and antagonists (Byant et al, 2003). Replacement of Pro $^{2}$ by alicyclic $\beta$-amino acids, pseudoprolines or piperidine- $2,-3$ and -4-carboxylic acids resulted in increased affinity for the MOR and enhanced proteolytic stability (Keller et al., 2001; Keresztes et al., 2008; Stamiszewska et al, 2008; Fichna et al., 2010). Phe ${ }^{4}$ in EM-1 has been suggested to be flexible and independent of the preceding three amino acids in terms of the orientation required by the receptor binding site (Paterlini et al., 2000). However, the results obtained for EM analogues in which $\mathrm{Phe}^{3}$ and $\mathrm{Phe}^{4}$ were replaced by $\beta \mathrm{MePhe}$ showed not only that the N-terminal tripeptide portion of the EMs contains key factors for the binding to the MOR, but also that the appropriate orientation of the C-terminal aromatic chain is important (Tomboly et al., 
2004). The insertion of $\mathrm{pFPhe}$ in place of the $\mathrm{Phe}^{4}$ in enkephalin or endomorphins resulted in increased potency in functional assays (Toth et al., 1990; Mallareddy et al., 2011).

Regarding the in vivo antinociceptive potency of endomorphin derivatives, several studies have investigated the effects of the ligands after systemic or i.c.v. administration in acute pain tests, while only a few studies are available on the effects of derivatives at spinal level. Furthermore, no data have been available about their effects in chronic pain models. Thus, different cyclic analogues of EM-2 induced more potent and/or prolonged antinociception in the hot-plate $(\mathrm{Hp})$ test after i.c.v. administration in mice compared to the parent ligand (Kruszynski et al., 2005; Perlikowska et al., 2009; Perlikowska et al., 2010). EM analogues containing D-amino acids also induced effective antinociception in mice assessed in Hp or TF test after i.c.v. administration (Liu et al., 2007; Perlikowska et al., 2010). EM analogues containing other natural (e.g. arginine) or non-natural aminoacids (e.g. phenylglycine or homophenylalanine) had more prolonged and/or more potent antinociception in acute heat pain tests after i.c.v. administration in mice (Gao et al., 2006; Yu et al., 2007; Wang et al., 2011). A number of studies proved that in contrast to the parent ligands, some analogues can produce antinociception after peripheral administration, too, which suggests that these substances can pass through the blood-brain barrier (Hau et al., 2002; Kruszynski et al., 2005; Shi et al., 2007; Perlikowska et al., 2010; Bedini et al, 2010; Wang et al, 2011). A few studies have found that analogues of EMs can antagonize opioid-induced antinociception after i.t. or i.c.v. administration in Hp or TF tests in mice (Sakurada et al., 2002; Fichna et al., 2005; Kruszynski et al, 2005; Mizoguchi et al, 2006).

EM-2 analogs containing N-methylated amino acids consecutively in each position showed the strongest analgesic effect when administered centrally in the Hp test in mice (Kruszynski et al., 2005). An earlier study showed that a dimethyl-analogue of EM-2 (Dmt ${ }^{1}$-EM-2) produced antinociception after i.t. injection in formalin test (rats) (Labuz et al., 2003). The effect evoked by Dmt ${ }^{1}$-EM-2 was similar to antinociceptive effect of EM-2 in the first phase, but it was much stronger in the second phase. As for our results, we found that EMD1 and EMD2 had similar effects as EM-2, and this is in agreement with their $\mathrm{K}_{\mathrm{i}}$ values for MOR, too (Mallaredy et al, 2011). EMD3 and EMD4 showed high potency to the MOR in vitro, and these ligands had also long halflife in a crude rat brain membrane homogenate (Mallaredy et al., 2011). Therefore, the 
activation of the MOR and their high metabolic stability could have led to prolonged antinociception in our model.

All of the above mentioned studies applied acute heat or chemical pain models. However, osteoarthritis, a widespread condition, affects several million patients in the world accompanied by chronic pain. Intra-articular injection of MIA in the joint of rats disrupts chondrocyte metabolism resulting in cartilage degeneration and subsequent nociceptive behavior that has been described as a model of osteoarthritis (OA) pain (Bove et al., 2010). An earlier study showed that the systemic administration of morphine reversed the hindlimb weight bearing decrease in this model (Pomonis et al., 2005). A recent study proved that MIA-induced joint pain is associated with significant changes in the spinal cord, too (Lee et al., 2011). Our study showed that i.t. applied morphine, EM-2 and derivatives can decrease the MIA-induced mechanical allodynia, supporting the role of the opioid receptors in the spinal cord in this type of pain as well. We found that new EM-2 analogues with unnatural amino acids produced dosedependent antinociception. In agreement with the in vitro results, the ligands with high potency at MOR and long half-life (EMD3 and EMD4) were the most effective in the in vivo tests.

To our knowledge, our results have been the first to demonstrate that complex modification of endomorphins by the introduction of Dmt, alicyclic $\beta$-amino acids, $\beta \mathrm{MePhe}$, and $\mathrm{pFPhe}$ in the EM- 2 can induce effective and prolonged antinociception in a chronic arthritis model. This structural modification of EM-2 might be a promising strategy to enhance bioavailability of peptides and may serve a role in the development of novel endomorphin analogues with increased therapeutic potential. Further studies are required to clarify the possible side-effects of these ligands.

\section{Series 2}

Our results showed that i.t. administration of $\mathrm{HP}$ after the induction of joint inflammation did not influence mechanical allodynia in a wide dose-range, but it did inhibit the antinociceptive effects of 2-AG.

So far only a few studies have investigated the in vivo and in vitro characteristics of HP. Conformation-state sensitive antibodies have been used for the investigation of binding characteristics of HP to different opioid, cannabinoid, adrenergic, bradykinin and angiotensin receptors in cell-lines and striatum (Heimann et al., 2007). It has been found 
that HP is an inverse agonist of $\mathrm{CB} 1$ receptors; thus, HP is able to block the constitutive activity of CB1 but not CB2 receptors (Heimann et al., 2007). A recent study has demonstrated that HP can antagonize CB1 agonist-induced internalization of the CB2 receptors in vitro (Dodd et al., 2010). As for the few earlier in vivo results, it has been observed that HP causes hypotension by the activation of nitric oxide release (Rioli et al., 2003; Blais et al., 2005; Lippton et al., 2006), and it induces hypophagia only in mice with functional CB1 receptors (Dodd et al., 2010).

Regarding the antinociceptive potency of HP, Dale et al. have found that intraplantarly administered HP $(0.1-20 \mu \mathrm{g})$ did not affect the paw pressure threshold in the noninflamed paws, but co-treatment with carrageenan or bradykinin significantly decreased the development of mechanical allodynia, as measured with the paw pressure test, and the effect was not inhibited by an opioid antagonist (Dale et al., 2005). Since the contralaterally administered HP was also effective in this respect, the data suggest systemic effects of the ligand. Orally (50 or $100 \mu \mathrm{g} / \mathrm{kg})$ or i.t. $(0.5$ or $5 \mu \mathrm{g})$ administered HP pretreatments were also effective in the same test (Heimann et al., 2007). I.p. administered HP (50 or $500 \mu \mathrm{g} / \mathrm{kg}$ ) exhibited marked antinociceptive potency in the acetic acid-induced visceral nociception model. This high dose of HP did not impair motor activity or alter pentobarbital-induced sleeping time, indicating the absence of unwanted sedative or motor side-effects. Unfortunately, we did not observe similar antinociceptive effects in our model. It is possible that the controversial results might be due to differences in the timing of the administration. That is, we applied HP after that mechanical allodynia had been established (post-treatment), while earlier studies prevented the development of the hyperalgesia (pre-treatment). Furthermore, there were differences either regarding the applied pain test (paw pressure vs von-Frey) or the site of administration of carrageenan (intraplantar vs intra-joint administration). In agreement with our results, the latest evidence suggests inefficacy of HP at spinal level in an acute heat pain test and in a neuropathic pain model (Hama and Sagen, 2011; Hama and Sagen, 2011). As for the HP pre-treatment before formalin administration, low dose of HP $(3 \mu \mathrm{g})$ decreased, but higher dose $(10 \mu \mathrm{g})$ enhanced the formalininduced nocifensive behavior. The authors have observed the inefficacy of HP as an antagonist after CB1 receptor activation. This is in contrast with our results, since HP, similarly to the synthetic CB1 antagonist, antagonized the antinociceptive effect of 2AG in our study. We suppose that the differences in the pain models and the applied 
cannabinoid ligand (WIN 55,212-2 vs 2-AG) might be the explanation of the different results.

Spinally administered anandamide and 2-AG significantly decreased the mechanical inflammatory pain sensitivity. The use of cannabinoids for the management of a wide range of painful disorders has been well documented at spinal, supraspinal, and peripheral levels (Pertwee, 2001; Hohmann, 2002; Guindon et al., 2007), while data about the endogenous ligands are scarce, especially at spinal level. Earlier studies have shown that i.t. anandamide decreases the acute heat pain sensitivity (in Hp and TF tests) and the carrageenan-induced thermal hyperalgesia in rodents, and that both the CB1 and TRPV1 receptors play a role in these effects (Yaksh et al., 2006; Horvath et al., 2008; Tuboly et al., 2009). To our knowledge, we have been the first to offer evidence to suggest that anandamide inhibits mechanical allodynia at the spinal level as well. Since several systems may be influenced by anandamide (e.g. CB-, TRPV1- glycine and serotonin-3 receptors), their net effect may be observed under these circumstances (Hajos et al., 2001; Oz et al., 2002; Kim et al., 2005; Lozovaya et al., 2005; Oz, 2006; Hejazi et al., 2006). As the high dose of anandamide caused temporary pain, the desensitization of TRPV1 receptors can also be involved in its antinociceptive effect, as suggested earlier (van der Stelt et al. 2005; Horvath et al., 2005). Therefore, it is possible that alterations in the release of excitatory and inhibitory transmitters can modify the activation of projection neurons, either pre-synaptically from primary sensory neurons or post-synaptically from interneurons, or both.

2-AG, similarly to anandamide, reduced allodynia in the carrageenan-induced arthritis model, and its antinociceptive effect was inhibited by a CB1 antagonist, while it was not influenced by a CB2 antagonist. This is the most abundant endogenous cannabinoid, and its concentration in the brain is 50-500 times as high as that of anandamide. It has also been identified peripherally (Kondo et al., 1998; Agarwal et al., 2000). 2-AG is a full agonist for $\mathrm{CB} 1$ and $\mathrm{CB}_{2}$ receptors with no direct binding to the TRPV1 receptor (Mechoulam et al., 1995). It is also a substrate for cyclooxygenase-2 (COX-2), and 2-AG is capable of suppressing elevation of $\mathrm{COX}-2$ expression by activating the CB1 receptors (Kozak et al., 2000; Zhang and Chen, 2008). There is only little evidence to support the antinociceptive potency of 2-AG. Endogenous 2-AG has been implicated as a major transmitter involved in endocannabinoid-mediated stress- 
induced analgesia (Hohmann et al., 2005; Suplita et al., 2006). Thus, 2-AG, but not anandamide, is mobilized in the lumbar spinal cord following exposure to footshock stress, and spinal 2-AG levels show marked correlation with stress-induced antinociception (Suplita et al., 2006; Hohmann et al., 2006). Additionally, i.t. administration of an inhibitor of the 2-AG hydrolyzing enzyme, MAGL, enhances stress-induced antinociception in a CB1-dependent manner (Suplita et al., 2006). In systemic administration to mice, $2-\mathrm{AG}\left(\mathrm{ED}_{50}=12.5 \mathrm{mg} / \mathrm{kg}\right)$ has caused antinociception in acute pain tests, immobility, reduction of spontaneous activity, and lowering of rectal temperature (Mechoulam et al., 1995; Ben Shabat, 1998). Topical administration of 2AG has also decreased the nocifensive behavior in a formalin test, decreased mechanical allodynia and thermal hyperalgesia in a neuropathic pain model, and it has also been effective in the alleviation of inflammatory joint pain (Guindon et al. 2007; Desroches et al., 2008; Mecs et al., 2010). The local antinociceptive effects of 2-AG have been prevented by CB1 and/or CB2 antagonists (Guindon et al., 2007; Desroches et al., 2008; Mecs et al., 2010). As far as the spinal level is concerned, we have been the first to show its antinociceptive potency, and that the effect is reversed by a CB1 antagonist drug (but not by a CB2 antagonist), suggesting that the antiallodynic effect of 2-AG is mainly due to the activation of $\mathrm{CB} 1$ receptors at spinal level. $\mathrm{CB} 1$ receptors, the molecular targets of 2-AG, are located on primary afferent fiber endings and/or on intrinsic interneurons in the dorsal horn of the spinal cord (Nyilas et al., 2009; Hegyi et al., 2009) therefore, their activation could lead to the observed antinociception.

It is important to consider that these ligands can influence the activity of neurons in the DRG too, since the cannabinoid receptors can be found on DRG neurons (Bridges et al., 2003; Sagar et al., 2005), and it has been shown that i.t. injection of sodium fluorescein results in massive staining in the DRG both in the cellular and fiber portions (Abram et al., 2006). As for the ineffectivity of CB1 and CB2 antagonists on inflamed and on the non-inflamed sides in themselves, a number of scenarios may be suggested. First, it might be supposed that the mechanical pain threshold after carrageenan administration $(\sim 10-15 \mathrm{~g})$ is a very low value, which could not be further decreased by an antagonist. However, the threshold on the normal side did not change either; therefore, this is not likely. Another possibility is that the endogenously released cannabinoids have no significant inhibitory effect on the mechanical threshold in inflammatory circumstances, either on the normal, or on the inflamed side. Similar results have been found in a bone 
cancer-induced pain model (Curto-Reyes et al., 2010) however, other studies have shown that i.t. injection of $\mathrm{CB} 1$ receptor antagonists can evoke nociceptive responses (Chapman, 1999; Lever and Malcangio, 2002). It is assumed that the differences in the pain models can lead to these controversial findings. However, the level of the released endogenous cannabinoids was not determined in our study; therefore, it cannot be decided whether this is due to the lack of production or the lack of effect of endogenous cannabinoid agonists.

In conclusion, we found that HP was not capable of influencing the established mechanical allodynia in a model of arthritic pain, but it inhibited the antinociceptive effects of 2-AG at spinal level. Furthermore, these findings are the first to demonstrate the antinociceptive potency of 2-AG at spinal level, and to report on the effect of anandamide on mechanical allodynia in an arthritic pain model. 


\section{Summary}

- It has been verified that derivatives of EM2 have similar in vivo potency to the original ligand in the osteoarthritic pain model.

- Effects of EMD3 and EMD4 were more prolonged suggesting long-lasting stability and high affinity to MOR, in vivo.

- Compared to morphine, which is a long-lasting pain analgetic, the EM2, EMD1 and EMD3 were efficient only in the first period (10-30 min), while the EMD4 was effective all along the period.

- Intrathecal administration of hemopressin was not capable of influencing the mechanical allodynia in a wide dose-range in the model of arthritic pain, but it inhibited the antinociceptive effects of $2-\mathrm{AG}$ at spinal level.

- Spinally administered anandamide and 2-AG significantly decreased mechanical inflammatory pain sensitivity.

- We proved the antinociceptive potency of 2-AG and that the effect is reversed by a CB1 antagonist drug, suggesting that the antiallodynic effect of $2-\mathrm{AG}$ is mainly due to the activation of $\mathrm{CB} 1$ receptors at spinal level. 


\section{References}

Abdelhamid EE, Sultana M, Portoges PS, Takemiri AE. Selective blockage of deltaopioid receptors prevents the development of morphine-tolerance and dependence in mice. Journal of Pharmacology and Experimental Therapeutics 1991;258: 299-303.

Abram SE, Yi J, Fuchs A, Hogan QH. Permeability of injured and intact peripheral nerves and dorsal root ganglia. Anesthesiology 2006;105: 146-53.

Agarwal N, Pacher P, Tegeder I, Amaya F, Constantin CE, Brenner GJ, et al. Cannabinoids mediate analgesia largely via peripheral type 1 cannabinoid receptors in nociceptors. Nature Neuroscience 2007;10: 870-9.

Ahluwalia J, Yaqoob M, Urban L, Bevan S, Nagy I. Activation of capsaicin-sensitive primary sensory neurones induces anandamide production and release. Journal of Neurochemistry 2003;84: 585-91.

Ahuja BR, Strunin L. Respiratory effects of epidural fentanyl changes in end-tidal $\mathrm{CO}_{2}$ and respiratory rate following single doses and continuous infusions of epidural fentanyl. Anaesthesia 1985;40: 949-55.

Akil H, Mayer DJ, Liebeskind JC. Antagonism of stimulation-produced analgesia by naloxone, a narcotic antagonist. Science 1976;191: 961-2.

Alexander SP, Kendall DA. The complications of promiscuity: Endocannabinoid action and metabolism. British Journal of Pharmacology 2007; 52: 602-23.

Albanese MC, Duerden EG, Rainville P, Duncan GH. Memory traces of pain in human cortex. Journal of Neuroscience 2007;27: 4612-20.

Aldrete JA, Couto da Silva JM. Leg edema from intratracheal opiate infusons. European Journal of Pain 2000;4: 361-5. 
Allen JW, Horais KA,Tozier AN, Yaksh TL. Opiate pharmacology of intrathecal granulomas Anesthesiology 2006;105: 590-8.

Almarestani L, Waters SM, Krause JR, Bennett GJ, Ribeiro-da-Silva A. Morphological characterization of spinal cord dorsal horn lamina I neurons projecting to the parabrachial nucleus in the rat. Journal of Comparative Neurology 2007;504: 287-97.

Anand U, Otto WR, Sanchez-Herrera D, Facer P, Yiangou Y, Korchev Y, et al. Cannabinoid receptor CB2 localisation and agonist-mediated inhibition of capsaicin responses in human sensory neurons. Pain 2008;138: 667-80.

Anderson VC, Burchiel KJ. A prospective study of long-term intrathecal morphine in the management of chronic nonmaligmant pain. Congress of Neurological Surgeons 1999;44: 289-300.

Bailey PL, Rhondeau S, Schafer PG, Lu JK, Timmins BS, Foster W, et al. Doseresponse pharmacology of intrathecal morphine in human volunteers. Anesthesiology 1993; 79: 49-59.

Bajic D, Proudfit HK. Projection of neuron sin the periaqueductal grey to pontine and medullary catacholamine cell groups involved in the modulation of nociception. Journal of Comparative Nerology 1999;405: 359-79.

Ballantyne JC, Loach AB, Carr DB. Itching aftrer epidural and spinal opiates Pain 1988;33: 149-60.

Bantick SJ, Wise RG, Ploghaus A, Clare S, Smith SM, Tracey I. Imaging how attention modulates pain in human using functional MRI Bain 2002; 125, 210-319.

Bar-Yehuda S, Rath-Wolfson L, Del Valle L, Ochaion A, Cohen S, Patoka R, et al. Induction of an antiinflammatory effect and prevention of cartilage damage in rat knee osteoarthritis by CF101 treatment. Arthritis and Rheumatology 2009;60: 3061-71 
Basbaum AI, Fields HL. The origin of descending pathways in the dorsolateral funiculus of the spinal cord of the cat and rat: Further studies on the anatomy of pain modulation Journal of Comparative Neurology 1979;3: 513-31.

Basbaum AI, Bautista DM, Scherrer G, Julius D. Cellular and molecular mechanisms of pain. Cell 2009;2: 267-84.

Basavarajappa BS, Hungund BL. Role of the endocannabinoid system in the development of tolerance to alcohol. Alcohol 2005;40:15-24.

Beecher HK. Pain in men wounded in battle. Annals of Surgery 1946;1 96-105.

Bedini A, Baiula M, Gentilucci L, Tolomelli A, De Marco R, Spampinato S. Peripheral antinociceptive effects of the cyclic endomorphin-1 analog c[YpwFG] in a mouse visceral pain model. Peptides 2010;31: 2135-40.

Behar M, Magora F, Olshwang D, Davidson JT. Epidural morphine in treatment of pain. Lancet 1979;8115: 527-9.

Ben Shabat S, Fride E, Sheskin T, Tamiri T, Rhee MH, Vogel Z, et al. An entourage effect: Inactive endogenous fatty acid glycerol esters enhance 2-arachidonoyl-glycerol cannabinoid activity. Eurean Journal of Pharmacology 1998;353: 23-31.

Bernards CM. Recent insights into the pharmacokinetics of spinal opioids and the relevance to opioid selection. Current Opinion in Anaesthesiology. 2004;5: 441-7.

Bernstein JE, Whitney DH, Soltani K. Inhibition of histamine induced pruritus by topcal triciclic antidepressants. Juornal of American Acedemic of Dermatology 1981;5: 55285 .

Bertie M, Starkstein S, Leiguarda R. Asymbolia for pain: A sensory-limbic disconnection syndrome. Annual Neurology 1988;1: 41-9. 
Bingel U, Tracey I. Imaging CNS modulation of pain in humans. Physiology 2008;6: $371-80$.

Bishop GH, Landau WM, Jones MH. Evidence for a double peripheral pathway for pain. Science 1958;128: 712-4.

Bisogno T, Melck D, Bobrov MYU, Gretsaya NM, Bezuglov V, De Petrocellis L, et al. $\mathrm{N}$-acyl-dopamines: Novel synthetic $\mathrm{CB}(1)$ cannabinoid-receptor ligands and inhibitors of anandamide inactivation with cannabimimetic activity in vitro and in vivo. Biochemical Journal 2000;351: 817-24.

Blais PA, Cote J, Morin J, Larouche A, Gendron G, Fortier A, et al. Hypotensive effects of hemopressin and bradykinin in rabbits, rats and mice: a comparative study. Peptides 2005;26: 1317-22.

Boly M, Faymonville ME, Schnakers C, Peigneux P, Lambermont B, Phillips C, et al. Perception of pain in the minimally conscious state with PET activation: An observational study. Lancet Neurology 2008;7: 1013-20.

Bonnardot JP, Mailiet M, Colau JC, Millot F, Deligne P. Maternal and fetal concentration of morphine after intrathecal administration during labour. British Journal of Anaesthesiology 1982; 54: 487-9.

Booth M. Opium: A history. New York: St. Martin’s Press; 1986.

Borgeat A, Ekatodramis G, Schenker CA. Postoperative nausea and vomiting in regional anesthesia: A review. Anesthesiology 2003;2: 530-47.

Bornhovd K, Quante M, Glauche V, Bromm B, Weiller C, Buchel C. Painful stimuli evoke different stimulus-response functions in the amygdala, prefrontal, insula and somatosensory cortex: A single-trial fMRI study. Brain 2002;125: 1326-36. 
Bove SE, Calcaterra SL, Brooker RM, Huber CM, Guzman RE, Juneau P, et al. Inflammatory compounds in a model of monosodium iodoacetate-induced weight bearing as a measure of disease progression and efficacy of anti-osteoarthritis. Osteoarthritis Cartilage 2003;11: 821-30.

British Pain Society www.britishpainsociety.org

Breivogel CS, Griffin G, Di Marzo V, Martin BR. Evidence for a new G proteincoupled cannabinoid receptor in mouse brain. Molecular Pharmacology 2001;60: 15563.

Bridges D, Rice ASC, Egertova M, Elphick MR, Winter J, Michael GJ. Localisation of cannabinoid receptor 1 in rat dorsal root ganglion using in situ hybridisation and immunohistochemistry. Neuroscience 2003;119: 803-12.

Brill S, Gurman GM, Fisher A. A history of neuraxial administration of local analgesics and opioids. European Journal of Anaesthesiology 2003;9: 682-9.

Brown SP, Safo PK, Regehr WG. Endocannabinoids inhibit transmission at granule cell to Purkinje cell synapses by modulating three types of presynaptic calcium channels. Journal of Neuroscience 2004;24: 5623-31.

Bryant SD, Jinsmaa Y, Salvadori S, Okada Y, Lazarus LH. Dmt and opioid peptides: A potent alliance. Biopolymers 2003;1: 86-102.

Cadas H, di Tomaso E, Piomelli H. Occurrence and biosynthesis of endogenous cannabinoid precursor, $\mathrm{N}$-arachidonoyl phosphatidylethanolamine, in rat brain. Journal of Neuroscience 1997;17: 1226-42.

Calignano A, La Rana G, Giuffrida A, Piomelli D. Control of pain initiation by endogenous cannabinoids. Nature 1998;394: 277-81. 
Capogna G, Celieno D, Tomassetti M. Maternal analgesia and neonatal effects of epidural sufentanil for cesarean section. Regional Anesthesiology 1989;14: 282-7.

Caudle RM, Finegold AA, Mannes AJ, Tobias MD, Kenshalo DR, Iadarola MJ. Spinal kappa1 and kappa2 opioid binding sites in rats, guinea pigs, monkeys and humans. NeuroReport 1998;9: 2523-5.

Caterina M, Schumacher MA, Tominaga M, RosenTA, Levine JD, Julius D. The capsaicin receptor: A heat-activated ion channel in the pain pathway. Nature 1997;389: 816-24.

Chaney MA. Side effects of intrathecal and epidural opioids. Canadian Journal of Anaesthesia 1995;42: 891-903.

Chapman V. The cannabinoid CB1 receptor antagonist, SR141716A, selectively facilitates nociceptive responses of dorsal horn neurones in the rat. British Journal of Pharmacology 1999;127: 1765-7.

Clark JA, Liu L, Price M, Hersh B, Edelson M, Pasternak GW. Kappa opiate receptor multiplicity: Evidence for two U50, 488-sensitive kappa 1 subtypes and a novel kappa 3 subtype. Journal of Pharmacology and Experimental Therapeutics 1989;251: 461-8.

Coombs DW, Fratkin JD, Meier FA, Nierenberg DW, Saunders RL. Neuropathologic lesions and CSF morphine concentrations during chronic continuous intraspinal morphine infusion. A clinical and postmortem study. Pain 1985; 22: 337-51.

Coombs DW, Colburn RW, DeLeo JA, Hoopes PJ, Twitchell BB. Comparative spinal neuropathology of hydromorphone and morphine after 9- and 30-day epidural administration in sheep. Anesthesia and Analgesia 1994; 78: 674-81.

Coyle DE. Partial peripheral nerve injury leads to activation of astroglia and microglia which parallels the development of allodynic behavior. Glia 1998;23: 75-83. 
Cowan A, Zhu XZ, Mosberg HI, Omnaas JR Porreca F. Direct dependence studies in rats with agents selective for different types of opioid receptor. Journal of Pharmacology and Experimental Therapeutics 1988;246: 950-5.

Cravatt BF, Demarest K, Patricelli MP, Giang DK, Martin BR, Lictman AH. Supersensitivity to anandamide and enhanced endogenous cannabinoid signalling in mice lacking fatty acid amide hydrolase. Proceedings of the National Academy of Sciences of the USA 2001;98: 9371-6.

Cristino L, de Petrocellis L, Pryce G, Baker D, Guglielmotti V, Di Marzo V. Immunohistochemical localization of cannabinoid type 1 and vanilloid transient receptor potential vanilloid type 1 receptors in the mouse brain. Neuroscience 2006;139: 1405-15.

Cui M, Feng Y, McAdoo DJ, Willis MD. Periaqueductal gray stimulation-induced inhibition of nociceptive dorsal horn neurons in rats is associated with the release of norepinephrine, serotonin, and amino acids. Journal of Pharmacology and Experimental Therapeutics 1999;289: 868-76.

Curto-Reyes V, Llames S, Hidalgo A, Menendez L, Baamonde A. Spinal and peripheral analgesic effects of the CB2 cannabinoid receptor agonist AM1241 in two models of bone cancer-induced pain. British Journal of Pharmacology 2010;160: 561-73.

Deadwyler SA, Hampson RE, Mu J, Whyte A, Childers S. Cannabinoids modulate voltage sensitive potassium A-current in hippocampal neurons via a cAMP-dependent process. Journal of Pharmacology and Experimental Therapeutics 1995;273: 734-43.

Decleration of $\quad$ Montreal $2013 \quad$ www.iasp-pain org./Content/NavigationMenu/Advocacy/DeclarationofMontr233al/default.htm

De Petrocellis L, Di Marzo V. Lipids as regulators of the activity of transient receptor potential type V1 (TRPV1) channels. Life Sciences, 2005;77: 1651-66. 
Desroches J, Guindon J, Lambert C, Beaulieu P. Modulation of the anti-nociceptive effects of 2-arachidonoyl glycerol by peripherally administered FAAH and MGL inhibitors in a neuropathic pain model. British Journal of Pharmacology 2008;155:91324.

Devane WA, Hanus L, Breuer A, Pertwee RG, Stevenson LA, Griffin G, et al. Isolation and structure of a brain constituent that binds to the cannabinoid receptor. Science 1992;258: 1946-9.

Dewey WL. Cannabinoid pharmacology. Pharmacological Reviews 1986;38: 151-78.

Di Marzo V, Deutsch DG. Biochemistry of the endogenous ligands of cannabinoid receptors. Neurobiology of Desease 1998;5: 386-404.

Di Marzo V, Breivogel CS, Tao Q, Bridgen DT, Razdan RK, Zimmer AM, et al. Levels, metabolism, and pharmacological activity of anandamide in CB1 cannabinoid receptor knockout mice: Evidence for non-CB1, non-CB2 receptor mediated actions in mouse brain. Journal of Neurochemistry 2000;75: 2434-44.

Di Marzo V, Bisogno T, De Petrocellis L. Anandamide: some like it hot. This concise and highly informative review provides background on the synthesis, uptake and breakdown of anandamide and discusses the recent evidence that anandamide is an endogenous ligand at vanilloid VR1 receptors. Trends in Pharmacological Sciences 2001;22: 346-9.

Di Marzo V, Blumberg PM, Szallasi A. Endovanilloid signaling in pain. Current Opinion in Neurobiology 2002;12: 372-9.

Di Marzo V, Petrocellis LD. Plant, synthetic, and endogenous cannabinoids in medicine. Annual Review of Medicine 2006;57: 553-74.

D’Mello R, Dickenson HA. Spinal cord mechanisms of pain. British Journal of Anaesthesiology 2008;101: 8-16. 
Di Chiro G, Grove SA. Evaluation of surgical and spontaneous cerebrospinal fluid shunts by isotope scanning. Journal of Neurosurgery 1966;24: 743-8.

Dinh TP, Carpenter D, Leslie FM, Freund TF, Katona I, Sensi SL, et al. Brain monoglyceride lipase participating in endocannabinoid inactivation. Proceedings of the National Academy of Sciences of the USA. 2002;99: 10819-24.

Dobos I, Toth K, Kekesi G, Joo G, Csullog E, Klimscha W, et al. The significance of intrathecal catheter location in rats. Anesthesia and Analgesia 2003;96: 487-92.

Dodd GT, Mancini G, Lutz B, Luckman SM. The peptide hemopressin acts through CB1 cannabinoid receptors to reduce food intake in rats and mice. Journal of Neuroscience 2010;30:7 369-76.

Dogliotti AM. Research and clinical observations on spinal anesthesia: With special reference to the peridural technique. Anesthesia and Analgesia 1933;12: 59-65.

Dogrul A, Ossipov MH, Porreca F. Differential mediation of descending pain facilitation and inhibition by spinal 5-HT-3 and 5-HT-7 receptors. Brain Research 2009;1280: 52-9.

Donadoni R, Rolly G, Noorduin H, Bussche GV. Epidural sufentanil for postoperative pain relief. Anaesthesia 1985;40: 634-8.

Doneen BA, Chung D, Yamashiro D, Law PY, Loh HH, Li CH. Beta-Endorphin: Structure-activity relationships in the guinea pig ileum and opiate receptor binding assays. Biochemical and Biophysical Research Communications 1977;74: 656-62.

Drew LJ, Harris J, Millns PJ, Kendall DA, Chapman V. Activation of spinal cannabinoid 1 receptors inhibits $\mathrm{C}$-fibre driven hyperexcitable neuronal responses and increases GTP $\gamma \mathrm{S}$ binding in the dorsal horn of the spinal cord of non-inflamed and inflamed rats. European Journal of Neuroscience 2000;12: 2079-86. 
Duncan M, Mouihate A, Mackie K, Keenan CM, Buckley NE, Davison JS, et al. Cannabinoid CB2 receptors in the enteric nervous system modulate gastrointestinal contractility in lipopolysaccharide-treated rats. American Journal of PhysiologyGastrointestinal Liver Physiology 2008;295: 78-87.

Eguchi M. Recent advances in selective opioid receptor agonists and antagonists. Medicinal Research Reviews 2004;24: 182-212.

Ersek M, Cherrier MM, Overman SS, Irving GA. The cognitive effects of opioids. Pain Management Nursing 2004;5: 75-93.

Esfandyari T, Camilleri M, Busciglio I, Burton D, Baxter K, Zinmeister AR. Effects of a cannabinoid receptor agonist on colonic motor and sensory functions in humans: A randomized, placebo-controlled study. American Journal of Physiology-Gastrointestinal Liver Physiology 2007;293: 137-45.

Etches RC, Sandler AN, Daley MD. Respiratory depression and spinal opioids. Canadian Journal of Anaesthesiology 1989;36: 165-85.

Felder CC, Joyce KE, Briley EM, Mansouri J, Mackie K, Blond O, et al. Comparison of the pharmacology and signal transduction of the human cannabinoid CB1 and CB2 receptors. Molecular Pharmacology 1995;48: 443-50.

Fichna J, do-Rego JC, Kosson P, Costentin J, Janecka A. Characterization of antinociceptive activity of novel endomorphin-2 and morphiceptin analogs modified in the third position. Biochemical Pharmacology 2005;69: 179-85.

Fichna J, do-Rego J-C, Kosson P, Schiller PW, Costentin J, Janecka A. Characterization of $\left[{ }^{35} \mathrm{~S}\right] \mathrm{GTP} \gamma \mathrm{S}$ binding stimulated by endomorphin- 2 and morphiceptin analogues in rat thalamus. Biochemical and Biophysical Research Communications 2006;345: 162-8. 
Fichna J, Gach K, Perlikowska R, Cravezic A, Bonnet JJ, do-Rego JC, et al. Novel endomorphin analogues with antagonist activity at the mu-opioid receptor in the gastrointestinal tract. Regulatory Peptides 2010;162: 109-14.

Fields HL, Bry J, Hentall I, Zorman G. The activity of neurons in the rostral medulla of the rat during withdrawal from noxious heat. Journal of Neuroscience 1983;3: 2545-52.

Fields HL, Malick A, Burstein R. Dorsal horn projection targets of ON and OFF cells in the rostral ventromedial medulla. Journal of Neurophysiology 1995;74: 1742-59.

Fields HL. Pain modulation: Expectation, opioid analgesia and virtual pain. Progress in Brain Research 2000;122: 245-53.

Fields HL. State-dependent opioid control of pain Nature Reviews Neuroscience 2004;5: 565-75.

Follett KA. Intrathecal opioid infusion. Anesthesiology 2004;101: 256-7.

Foltz EL, White Jr LE. Pain relief by frontal cingulumotomy. Journal of Neurosurgery 1962;19: 89-100.

Fowler CJ. Anamdamid uptake explained? Trends in Pharmacological Sciences 2012;33: 181-5.

Fuller JG, McMorland GH, M Douglas MJ, Palmer L. Epidural morphine for analgesia after Caesarean section: A report of 4880 patients. Canadian Journal of Anaesthesia 1990;37: 636-40.

Galiègue S, Mary S, Marchand J, Dussossoy D, Carrière D, Carayon P, et al. Expression of central and peripheral cannabinoid receptors in human immune tissues and leukocyte subpopulations. European Journal of Biochemistry 1995;5: 54-61. 
Gao K, Kim YHH, Mason P. Serotonergic pontomedullary neurons are not activated by antinociceptive stimulation in the periaqueductal gray. Journal of Neuroscience 1997; 17: 3285-92.

Gao Y, Liu X, Liu W, Qi Y, Liu X, Zhou Y, et al. Opioid receptor binding and antinociceptive activity of the analogues of endomorphin- 2 and morphiceptin with phenylalanine mimics in the position 3 or 4 . Bioorganic and Medical Chemistry Letters 2006;16: 3688-92.

Gauriau C, Bernard JF. Pain pathways and parabrachial circuits in the rat. Experimental Physiology 2002;87: 251-8.

Gauriau C, Bernard JF. A comparative reappraisal of projections from the superficial laminae of the dorsal horn in the rat: The forebrain. Journal of Comparative Neurology 2004;468: 24-56.

Gehling M, Thryba M. Risks and side-effects of intrathecal morphine combined with spinal anasthaesia: Meta-analysis. Anasthaesia 2009;64: 634-51.

Ghafouri N, Tiger G, Razdan RK, Mahadevan A, Pertwee RG, Martin BR, et al. Inhibition of monoacylglycerol lipase and fatty acid amide hydrolase by analogues of 2arachidonoylglycerol. British Journal of Pharmacology 2004;143: 774-84.

Gilbert AK. Franklin KBJ. GABAergic modulation of descending inhibitory systems from the rostral ventromedial medulla (RVM). Dose-response analysis of nociception and neurological deficits. Pain 2001;90: 25-36.

Gintzler AR, Adapa ID, Toll L, Medina VM, Wang L. Modulation of enkephalin release by nociceptin (orphanin FQ). European Journal of Pharmacology 1997;325: 2934. 
Glaser ST, Abumrad NA, Fatade F, Kaczocha M, Studholme KM, Deutsch DG. Evidence against the presence of an anan-damide transporter. Proceedings of the National Academy of the Sciences of the USA 2003;100: 4269-74.

Goldberg IE, Rossi GC, Letchworth SR, Mathis JP, Ryan-Moro J, Leventhal L, et al. Pharmacological characterization of endomorphin-1 and endomorphin-2 in mouse brain. Journal of Pharmacology and Experimental Therapeitics 1998;286: 1007-13.

Goldstein A, Tachibana S, Lowney L, Hunkapiller M, Hood L. Dynorphin (1-13), an extraordinary potent opioid peptide. Proceedings National Academy of the Sciences of the USA 1979;76: 6666-70.

Golech SA, McCarron RM, Chen Y, Bembry J, Lenz F, Mechoulam R. Human brain endothelium: Coexpression and function of vanilloid and endocannabinoid receptors. Molecular Brain Research 2004;132: 87-92.

Gomes I, Grushko JS, Golebiewska U, Hoogendoorn S, Gupta A, Heimann AS, et al. Novel endogenous peptide agonists of cannabinoid receptors. FASEB Journal 2009;23, 3020-9.

Gong JP, Onaivi ES, Ishiguro H, Liu QR, Tagliaferro PA, Brusco A, et al. Cannabinoid CB2 receptors: Immunohis-tochemical localization in rat brain. Brain Research 2006;1071: 10-23.

Grudt TJ, Perl ER. Correlations between neuronal morphology and electrophysiological features in the rodent superficial dorsal horn. Journal of Physiology 2002;540: 189-207.

Guindon J, Desroches J, Beaulieu P. The antinociceptive effects of intraplantar injections of 2-arachidonoyl glycerol are mediated by cannabinoid CB2 receptors. British Journal of Pharmacology 2007;150: 693-701. 
Guindon J, Hohmann AG. Cannabinoid CB2 receptors: A therapeutic target for the treatment of inflammatory and neuropathic pain. British Journal of Pharmacolology 2008;153: 319-34.

Gulyas AI, Cravatt BF, Bracey MH, Dinh TP, Piomelli D, Boscia F, et al. Segregation of two endocannabinoid-hydrolyzing enzymes into pre- and postsynaptic compartments in the rat hippocampus, cerebellum and amygdala. European Journal of Neuroscience 2004;20: 441-58.

Gustafsson LL, Schildt B, Jacobsen K. Adverse effect of exradural and intratechal opiats: Report of a nationwide survey in Sweden. British Journal of Anasthesia 1992;81: 86-93.

Gwirtz KH, Young JV, Byers RJ, Alley C, Levin K, Walker SG, et al. The safety and efficacy of intrathecal opioid analgesia for acute postoperative pain: Seven years experience with 5969 surgical patients at Indiana University Hospital. Anesthesia and Analgesia 1999;88: 599-604.

Hackler L, Zadina JE, Ge LJ, Kastin AJ. Isolation of relatively large amounts of endomorphin-1 and endomorphin-2 from human brain cortex. Peptides 1997;18: 16359.

Hajos N, Ledent C, Freund TF. Novel cannabinoid-sensitive receptor mediates inhibition of glutamatergic synaptic transmission in the hippocampus. Neuroscience 2001;106: 1-4.

Hama A, Sagen J. Activation of spinal and supraspinal cannabinoid-1 receptors leads to antinociception in a rat model of neuropathic spinal cord injury pain. Brain Research 2011;1412: 44-54.

Hama A, Sagen J. Centrally mediated antinociceptive effects of cannabinoid receptor ligands in rat models of nociception. Pharmacology Biochemistry Behavior 2011;100: 340-6. 
Hanus L, Breuer A, Tchilibon S, Shiloah S, Goldenberg D, Horowitz M, et al. HU-308: a specific agonist for $\mathrm{CB}(2)$, a peripheral cannabinoid receptor. Proceedings National Academy of the Sciences of the USA 1999;96: 14228-33.

Hargreaves KM, Dubner R, Brown F, Flores C, Joris J. A new and sensitive method for measuring thermal nociception in cutaneous hyperalgesia. Pain 1988;32: 77-88.

Harris JD, Kotob F. Management of opioid-related side effects. In De LeonCasasola OA, Cancer Pain. Saunders, 2006. Chapter 18:212-230.

Hau VS, Huber JD, Campos CR, Lipkowski AW, Misicka A, Davis TP. Effect of guanidino modification and proline substitution on the in vitro stability and blood-brain barrier permeability of endomorphin II. Journal of Pharmaceutical Sciences 2002;91: 2140-9.

Hayashi H, Sumino R, Sessle BJ. Functional organization of trigeminal subnucleus interpolaris: Nociceptive and innocuous afferent inputs, projections to thalamus, cerebellum, and spinal cord, and descending modulation from periaqueductal gray. Journal of Neurophysiology 1984;51: 890-5.

Haythornthwaite JA, Menefee LA, Quatrano-Piacentini AL, Pappagallo M. Outcome of chronic opioid therapy for non-cancer pain. Journal of Pain and Symptom Management 1998;15: 185-94.

Hegyi Z, Kis G, Hollo K, Ledent C, Antal M. Neuronal and glial localization of the cannabinoid-1 receptor in the superficial spinal dorsal horn of the rodent spinal cord. European Journal of Neuroscience 2009;30: 251-62.

Heimann AS, Gomes L, Dale CS, Pagano RL, Gupta A, de Souza LL, et al. Hemopressin is an inverse agonist of CB1 cannabinoid receptors. Proceedings of the National Academy of Sciences of the USA 2007;104: 20588-93. 
Heinricher MM, Neubert NJ. Neural basis for the hyperalgesic action of cholecystokinin in the rostral ventromedial medulla. Journal of Neurophysiology 2004;92: 1982-9.

Heinricher MM, Tavares I, Leith JL, Lumb BM. Descending control of nociception: specificity, recruitment and plasticity. Brain Research Reviews 2009;60: 214-25.

Hejazi N, Zhou C, Oz M, Sun H, Ye JH, Zhang L. Delta9-tetrahydrocannabinol and endogenous cannabinoid anandamide directly potentiate the function of glycine receptors. Molecular Pharmacology 2006;69: 991-7.

Herkenham M, Lynn AB, Little MD, Johnson MR, Melvin 1S, de Costa BR, et al. Cannabinoid receptor localization in brain. Proceedings of. the National Academy of Sciences of the USA 1990;87: 1932-6.

Herkenham M, Lynn AB, Johnson MR, Melvin LS, de Costa B. R, Rice KC. Characterization and localization of cannabinoid receptors in rat brain: A quantitative in vitro autoradiographic study. Journal of Neuroscience 1991;11: 563-83.

Herzberg U, Eliav E, Bennett GJ, Kopin IJ. The analgesic effects of R(+)-WIN 55,2122 mesylate, a high affinity cannabinoid agonist, in a rat model of neuropathic pain. Neuroscience Letters 1997;221:157-60.

Hohmann AG, Tsou K, Walker JM. Cannabinoid modulation of wide dynamic range neurons in the lumbar dorsal horn of the rat by spinally administered WIN55,212-2. Neuroscience Letters 1998;257: 119-22.

Hohmann AG, Herkenham M. Regulation of cannabinoid and mu opioid receptors in rat lumbar spinal cord following neonatal capsaicin treatment. Neuroscience Letters 1998;252: 13-6.

Hohmann AG. Spinal and peripheral mechanisms of cannabinoid antinociception: Behavioral, neurophysiological and neuroanatomical perspectives. Chemistry and Physics of Lipids 2002;121: 173-90. 
Hohmann AG, Suplita RL, Bolton NM, Neely MH, Fegley D, Mangieri R, et al. An enocannabinoid mechanism for stress-induced analgesia. Nature 2005;435: 1108-12.

Hohmann AG, Suplita RL. Endocannabinoid mechanisms of pain modulation. AAPS Journal 2006;8: 693-708.

Horvath G. Endomorphin-1 and endomorphin-2: Pharmacology of the selective endogenous $\mu$-opioid receptor agonists. Pharmacology and Therapeutics 2000;88: 43763.

Horvath G, Kekesi G, Nagy E, Benedek G. The role of TRPV1 receptors in the antinociceptive effect of anandamide at spinal level. Pain 2008;134: 277-84.

Howlett AC. Inhibition of neuroblastoma adenylate cyclase by cannabinoid and nantradol compounds. Life Science 1984;35: 1803-10.

Howlett AC, Barth F, Bonner TI, Cabral G, Casellas P, Devane WA, et al. International Union of Pharmacology. XXVII. Classification of cannabinoid receptors. Pharmacological Rewiews 2002;54: 161-202.

Hruby VJ, Li GG, Haskell-Luevano C, Shenderovich M. Design of peptides, proteins, and peptidomimetics in chi space. Biopolymers 1997;43: 219-66.

Huang SM, Bisogno T, Trevisani M, Al-Hayani A, De Petrocellis L, Fezza F, et al. An endogenous capsaicin-like substance with high potency at recombinant and native vanilloid VR1 receptors. Proceedings of the National Academy of Science of the USA 2002;99: 8400-05.

Hughes J, Smith T, Kosterlitz H, Fothergill L, Morgan B, Morris H. Identification of two pentapeptides from the brain with potent opiate agonist activity. Nature 1975;258: $577-9$. 
Hung K-C, Wu H-E, Mizoguchi H, Leitermann R, Tseng LF. Intrathecal treatment with 6-hydroxydopamine or 5,7-dihydroxytryptamine blocks the antinociception induced by endomorphin-1 and endomorphin-2 given intracerebroventricularly in the mouse. Journal of Pharmacological Sciences 2003;93: 299-306.

Iggo A, Ogawa H. Primate cutaneous thermal nociceptors. Journal of Physiology 1971;216: 77-8.

Izzo AA, Mascolo N, Capasso F. The gastrointestinal pharmacology of cannabinoids. Current Opinon of Pharmacology 2001;1: 597-603.

Janecka A, Fichna J, Janecki T. Opioid receptors and their ligand. Current Topics in Medical Chemistry 2004;4: 1-17.

Jessop DS, Major GN, Coventry TL, Kaye SJ, Fulford AJ, Harbuz M Set al. Novel opioid peptides endomorphin-1 and endomorphin- 2 are present in mammalian immune tissues. Journal of Neuroimmunology 2000;106: 53-9.

Jordt SE, Julius D. Molecular basis for species-specific sensitivity to "hot" chili peppers. Cell 2002;108: 421-430.

Kakizawa K, Shimohira I, Sakurada S, Fujimura T, Murayama K, Ueda H. Parallel stimulations of in vitro and in situ $\left[{ }^{35} \mathrm{~S}\right] \mathrm{GTP} \gamma \mathrm{S}$ binding by endomorphin 1 and DAMGO in mouse brains. Peptides 1998;19: 755-8.

Kandel ER, Schwartz JH, Jessell TM. Principles of Neural Science 4 th edition McGraw-Hill, New York ISBN 0-8385-7701-6.

Karbarz MJ, Luo L, Chang L, Tham CS, Palmer JA, Wilson SJ. Biochemical and biological properties of 4-(3-phenyl-[1, 2,4] thiadiazol-5-yl)-piperazine-1-carboxylic acid phenylamide, a mechanism-based inhibitor of fatty acid amide hydrolase. Anesthesia and Analgesia 2009;108: 316-29. 
Kato G, Yasaka T, Katafuchi T, Furue H, Mizumo M, Iwamoto Y, et al. Direct GABAergic and glycinergic inhibition of the substantia gelatinosa from the rostral ventromedial medulla revealed by in vivo patch-clamp analysis in rats. Journal of Neuroscience 2006;26: 1787-94.

Kathuria S, Gaetani S, Fegley D, Valino F, Duranti A, Tontini A. Modulation of anxiety through blockade of anandamide hydrolysis. Nature Medicine 2003;9: 76-81.

Keller M, Boissard C, Patiny L, Chung NN, Lemieux C, Mutter M, et al. Pseudoprolinecontaining analogues of morphiceptin and endomorphin-2: Evidence for a cis Tyr-Pro amide bond in the bioactive conformation. Journal of Medical Chemistry 2001;44: 3896-03.

Keresztes A, Szucs M, Borics A, Kover KE, Forro E, Fulop F, et al. New endomorphin analogues containing alicyclic beta-amino acids: Influence on bioactive conformation and pharmacological profile. Journal of Medical Chemistry 2008;51: 4270-9.

Kim HI, Kim TH, Shin YK, Lee CS, Park M, Song JH. Anandamide suppression of $\mathrm{Na}^{+}$ currents in rat dorsal root ganglion neurons. Brain Research 2005;1062: 39-47.

Knapp RJ, Malatynska E, Collins N, Fang L, Wang JY, Hruby VJ, et al. Molecularbiology and pharmacology of cloned opioid receptors. Faseb Journal 1995;7: 516-25.

Kondo S, Kondo H, Nakane S, Kodaka T, Tokumura A, Waku K, et al. 2arachidonoylglycerol, an endogenous cannabinoid receptor agonist: Identification as one of the major species of monoacylglycerols in various rat tissues, and evidence for its generation through $\mathrm{Ca}^{2+}$-dependent and -independent mechanisms. FEBS Letters 1998;429: 152-6.

Kozak KR, Rowlinson SW, Marnett LJ. Oxygenation of the endocannabinoid, 2arachidonylglycerol, to glyceryl prostaglandins by cyclooxygenase-2. Journal of Biological Chemistry 2000;275: 33744-9. 
Kruszynski R, Fichna J, Do-Rego JC, Chung NN, Schiller PW, Kosson P, et al. Novel endomorphin-2 analogs with mu-opioid receptor antagonist activity. Journal of Peptide Research 2005;66: 125-31.

Kwiat GC, Bisbaum AI. The origin of brainstem noradrenergic and serotoninergic projections to the spinal cord dosrsal horni $\mathrm{n}$ the rat. Somatosenory and Motor Research 1992;9: 157-73.

Labuz D, Chocyk A, Wedzony K, Toth G, Przewlocka B. Endomorphin-2, deltorphin II and their analogs supress formaline-induced nociception and c-Fos expression in the rat spinal cord. Life Science 2003;73: 403-12.

Lahti RA, Mickelson MM, McCall JM, Von Voigtlander PF. [3H]U-69593 a highly selective ligand for the opioid $\kappa$-receptor. European Journal of Pharmacology 1985;109: 281-4.

LaMotte RH, Thalhammer JG. Response properties of high-threshold cutaneous cold receptors in the primate. Brain Research 1982;244: 279-87.

Langsam A. Spinal cord compression by cathether granulomas in high-dose intrathecal morphine therapy: Case riport. Neurosurgery 1999;44: 689-91.

Lapirot O, Melin C, Modolo A, Nicolas C, Messaoudi Y, Monconduit L, et al. Tonic and phasic descending dopaminergic controls of nociceptive transmission in the medullary dorsal horn. Pain. 2011;152: 1821-31.

Law PY, Loh HH. Regulation of opioid receptor activities. Journal of Pharmacology and Experimental Therapeutics 1999;289: 607-24.

Lawlor PG. The panorama of opioid-related cognitive dysfunction in patients with cancer. Cancer 2002;94: 1836-53. 
Lawson SN, Caddy KWT, Biscoe TJ. Development of rat dorsal root ganglion neurones: Studies on changes in cell birthday and changes in mean cell diameter. Cell and Tissue Research 1974;153: 399-412.

Lawson SN, Biscoe TJ. Development of mouse dorsal root ganglia: An autoradiographic and quantitative study. Journal of Neurocytology 1979;8: 265-74.

Lee Y, Pai M, Brederson JD, Wilcox D, Hsieh G, Jarvis M, et al. Monosodium iodoacetate-induced joint pain is associated with increased phosphorylation of mitogen activated protein kinases in the rat spinal cord. Molecular Pain 2011;7: 39.

Lever IJ, Malcangio M. CB1 receptor antagonist SR141716A increases capsaicinevoked release of Substance $\mathrm{P}$ from the adult mouse spinal cord. British Journal of Pharmacology 2002;135: 21-4.

Li CH, Chung D, Doneen BA. Isolation, characterization and opiate activity of betaendorphin from human pituitary glands. Biochemical and Biophysical Research Communications 1976;72: 1542-7.

Li J, Daughters RS, Bullis C, Bengiamin R, Stucky MW, Brennan J, et al. The cannabinoid receptor agonist WIN 55,212-2 blocks the development of hyperalgesia produced by capsaicin in rats. Pain 1999; 81: 25-34.

Lichtman AH, Cook SA, Martin BJ. Investigation of brain sites mediating cannabinoidinduced antinociception in rats: Evidence supporting periaqueductal gray involvement. Journal of Pharmacology and Experimental Therapeutics 1996;276: 585-93.

Lippton H, Lin B, Gumusel B, Witriol N, Wasserman A, Knight M. Hemopressin, a hemoglobin fragment, dilates the rat systemic vascular bed through release of nitric oxide. Peptides 2006;27: 2284-8.

Liu H, ZhangB, LiuX, WangC, NiJ, Wang R. Endomorphin-1 analogs with enhanced metabolic stability and systemic analgesic activity: Design, synthesis, and 
pharmacological characterization. Bioorganic and Medicinal Chemistry 2007;15: 16941702.

Liu M, Wittbrodt E. Low-dose oral naloxone reverses opioid-induced constipation and analgesia. Journal of Pain and Symptom Management 2002;23: 48-53.

Lozovaya N, Yatsenko N, Beketov A, Tsintsadze T, Burnashev N. Glycine receptors in CNS neurons as a target for nonretrograde action of cannabinoids. Journal of Neuroscience 2005;25: 7499-506.

Lu Y, Perl ER. Modular organization of excitatory circuits between neurons of the spinal superficial dorsal horn (laminae I and II). Journal of Neuroscience 2005;25: 3900-07.

Lunn CA, Fine J, Rojas-Triana A, Jackson JV, Lavey B, Kozlowski JA, et al Cannabinoid $\mathrm{CB}_{2}$-selective inverse agonist protects against antigen-induced bone loss. Immunopharmacology and Immunotoxicology 2007;29: 387-401.

Lynn AB, Herkenham M. Localization of cannabinoid receptors and nonsaturable highdensity cannabinoid binding sites in peripheral tissues of the rat: Implications for receptor-mediated immune modulation by cannabinoids. Journal of Pharmacology and Experimental Therapeutics 1994;268: 1612-23.

Maccarrone M, Wenger T. Effects of cannabinoids on hypothalamic and reproductive function. Handbook of Experimental Pharmacology 2005;168: 555-71.

Maione S, Bisogno T, de Novellis V, Palazzo E, Cristino L, Valenti M, et al. Elevation of endocannabinoid levels in the ventrolateral periaqueductal grey through inhibition of fatty acid amide hydrolase affects descending nociceptive pathways via both cannabinoid receptor type 1 and transient receptor potential vanilloid type- 1 receptors. Journal of Pharmacology and Experimetal Therapeutics 2006;316: 969-82. 
Malan TP. Jr., Ibrahim MM, Deng H, Liu Q, Mata HP, Vanderah T, et al. $\mathrm{CB}_{2}$ cannabinoid receptor-mediated peripheral antinociception. Pain 2001;93: 239-45.

Malinowsky JM, Pinaud M. Neorotoxicity of ontratechally administrated agent. Annales Franceses Anesthésie et de Reanimation 1996;15: 647-58.

Mallareddy JR, Borics A, Keresztes A, Kover KE, Tourwe D, Toth G. Design, synthesis, pharmacological evaluation, and structure-activity study of novel endomorphin analogues with multiple structural modifications. Journal of Medical Chemistry 2011;54: 1462-72.

Mansour A, Khachaturian H, Lewis ME, Akil H, Watson SJ. Anatomy of CNS opioid receptors. Trends in Neuroscience 1988;11: 308-14.

Mao J, Sung B, Ji R-R, Lim G. Neuronal apoptosis associated with morphine tolerance: Evidence for an opioid-induced neurotoxic mechanism. Journal of Neuroscience 2002;22: 7650-61.

Martin WJ, Coffin PO, Attias E, Balinsky M, Tsou K, Walker JM. Anatomical basis for cannabinoid-induced antinociception as revealed by intracerebral microinjections. Brain Research 1999,822: 237-42.

Martin-Schild S, Zadina JE, Gerall AA, Vigh S, Kastin AJ. Localization of endomorphin-2-like immunoreactivity in the rat medulla and spinal cord. Peptides 1997;18: 1641-49.

Martin-Schild S, Gerall AA, Kastin AJ, Zadina JE. Endomorphin-2 is an endogenous opioid in primary sensory afferent fibers. Peptides 1998;19: 1783-9.

Martin-Schild S, Gerall AA, Kastin AJ, Zadina JE. Differential distribution of endomorphin 1- and endomorphin-2-like immunoreactivities in the CNS of the rodent. Journal of Comparative Neurology 1999;405: 450-71. 
Matsuda LA, Lolait SJ, Brownstein MJ, Young AC, Bonner TT. Structure of a cannabinoid receptor and functional expression of the cloned cDNA. Nature 1990;346: $561-4$.

Maxwell DJ, Belle MD, Cheunsuang O, Stewart A, Morris R. Morphology of inhibitory and excitatory interneurons in superficial laminae of the rat dorsal horn. Journal of Physiology 2007;584: 521-33.

Mayer D, Liebeskind JC. Pain reduction by focal electrical stimulation of the brain: An anatomical and behavioral analysis. Brain Research 1974;68: 73-93.

Mazzola L, Isnard J, Mauguière F. Somatosensory and pain responses to stimulation of the second somatosensory area (SII) in humans. A comparison with SI and insular responses. Cerebral Cortex 2006; 7: 960-8.

Mazzola L, Isnard J, Peyron R, Mauguiere F. Stimulation of the human cortex and the experience of pain: Wilder Penfield's observations revisited. Brain. 2012;135: 631-40.

McMillan MR. Intrathecal morphine and inflammatory masses. Anesthesiology 2004; 101: 255

Mechoulam R, Ben Shabat S, Hanus L, Ligumsky M, Kaminski NE, Schatz AR, et al. Identification of an endogenous 2-monoglyceride, present in canine gut, that binds to cannabinoid receptors. Biochemical Pharmacology 1995;50: 83-90.

Mecs L, Tuboly G, Toth K, Nagy E, Nyari T, Benedek G, et al. Peripheral antinociceptive effect of 2-arachidonoyl-glycerol and its interaction with endomorphin1 in arthritic rat ankle joints. Clinical and Experimental Pharmacology and Physiology 2010;37: 544-50.

Mercandante S, Ferrera P, Villari P, Arcuri E. Hyperalgesia: An emerging iatrogenic syndrome. Journal of Pain Symptom Management 2003; 26: 769-75. 
Melzack R. Pain and the neuromatrix in the brain. Journal of Dental Education 2001;65: 1378-82.

Merskey H, Bogduk N. Classification of chronic pain descriptions of chronic pain syndromes and definitions of pain terms. IASP Press International Association for the Study of Pain 1994909 NE 43rd St., Suite 306

Meylan N, Elia N, Lysakowski C, Tramèr MR. Benefit and risk of intrathecal morphine without local anaesthetic in patients undergoing major surgery: Meta-analysis of randomized trials. British Journal of Anaesthesia 2009;102: 156-67.

Meunier JC, Mollereau C, Toll L, Suaudeau C, Moisand C, Alvinerie P, et al. Isolation and structure of the endogenous agonist of opioid receptor-like ORL1 receptor. Nature 1995;377: 532-5.

Mizoguchi H, Nakayama D, Watanabe H, Ito K, Sakurada W, Sawai T, et al. Involvement of spinal mul-opioid receptors on the Tyr-d-Arg-Phe-sarcosine-induced antinociception. European Journal of Pharmacolology 2006;540: 67-72.

Mogil JS, Grisel JE, Zhangs G, Belknap JK, Grandy DK. Functional antagonism of mudelta- and kappa-opioid antinociception by orphanin FQ. Neuroscience Letters 1996;214: 131-4.

Mollereau C, Parmentier M, Mailleux P, Botour JL, Moisand C, Chalon P, et al. ORL1, a novel member of the opioid receptor family: Cloning, functional expression and localization. FEBS Letters 1994;341: 33-8.

Moreau L, Fields HL. Evidence for GABA involvement in midbrain control of medullary neurons that modulate nociceptive transmission. Brain Research 1986;397: $37-46$. 
Morgese MG, Cassano T, Cuomo V, Giuffrida A. Anti-dyskinetic effects of cannabinoids in a rat model of Parkinson's disease: Role of CB1 and TRPV1 receptors. Experimental Neurology 2007;208: 110-9.

Moulin DE, Iezzi A, Amireh R, Sharpe WK, Boyd D, Merskey H. Randomised trial of oral morphine for chronic non-cancer pain. Lancet. 1996; 347: 143-7.

Mousa SA, Machelska H, Schafer M, Stein C. Immunohistochemical localization of endomorphin-1 and endomorphin-2 in immune cells and spinal cord in a model of inflammatory pain. Journal of Neuroimmunology 2002;126: 5-15.

Mugabure Bujedo B, González-Santos S, and Uría Azpiazu A. A review of epidural and intrathecal opioids used in the management of postoperative. Journal of Opioid Management 2012;8: 177-92.

Munro S, Thomas KL, Abu-Shaar M. Molecular characterization of a peripheral receptor for cannabinoids.Nature 1993;365: 61-5.

Nissl F. Über die sogenannten granula der nervenzellen. Neurologisches Zentralblatt 1984;13:676-85.

North RB, Cutchis RN, Epstein JA, Mong DM. Spinal cord compression complicating subarachnoid infusion of morphine: Case report and laboratory experience. Neurosurgery 1991;29: 778-84.

Nybell-Lindahl G, Carlsson C, Ingemarsson I, Westgren M, Paalzow L. Maternal and fetal concentrations of morphine after epidural administration during labor. American Journal of Obstetrics and Gynecology 1981;139: 20-1.

Nyilas R, Gregg LC, Mackie K, Watanabe M, Zimmer A, Hohmann AG, et al. Molecular architecture of endocannabinoid signaling at nociceptive synapses mediating analgesia. European Journal of Neuroscience 2009;29: 1964-78. 
Ochsner KN, Gross JJ. The cognitive control of emotion. Trends in Cognitive Sciences 2005;9: 242-9.

Odeh F, Antal M. The projections of the midbrain periaqueductal grey to the pons and medulla oblongata in rats. European Journal of Neuroscience 2001;14: 1275-86.

Onofrio BM, Yaksh TL, Arnold PG. Continuous low-dose intrathecal morphine administration in the treatment of chronic pain of malignant origin. Mayo Clinic Proceeding Journal 1981;56: 516-20.

Ofek O, Karsak M, Leclerc N, Fogel M, Frenkel B, Wright K, et al. Peripheral cannabinoid receptor CB2, regulates bone mass. Proceedings of the National Academy of Sciences of the USA 2006;103:696-701.

Okamoto Y, Wang J, Morishita J, Ueda N. Biosynthetic pathways of the endocannabinoid anandamide. Chemistry and Biodiversity 2007;4: 1842-57.

Olson GA, Olson RD, Vaccarino AL, Kastin AJ. Endogenous opiates. Peptides 1998;19: 1791-843.

Ostrowsky K, Magnin M, Ryvlin P, Isnard J, Guenot M, Mauguiere F. Representation of pain and somatic sensation in the human insula: A study of responses to direct electrical cortical stimulation. Cerebral Cortex 2002;12: 376-85.

Oz M, Zhang L, Morales M. Endogenous cannabinoid, anandamide, acts as a noncompetitive inhibitor on $5-\mathrm{HT}_{3}$ receptor mediated responses in oocytes. Synapse 2002;46: 150-6.

Oz M, Ravindran A, Diaz-Ruiz O, Zhang L, Morales M. The endogenous cannabinoid anandamide inhibits $\alpha_{7}$ nicotinic acetylcholine receptor-mediated responses in Xenopus oocytes. Journal of Pharmacology and Experimental Therapeutics 2003;306: 1003-10. 
Oz M, Jackson SN, Woods AS, Morales M, Zhang L. Additive effects of endogenous cannabinoid anandamide and ethanol on $\alpha_{7}$-nicotinic acetylcholine receptor-mediated responses in Xenopus oocytes. Jouernal of Pharmacolology and Experimental Therapeutics 2005;313: 1272-1280.

Oz M. Receptor-independent actions of cannabinoids on cell membranes: Focus on endocannabinoids. Pharmacology and Therapeutics 2006;111: 114-44.

Pacher P, Mukhopadhyay P, Mohanraj R, Godlewski G, Bakai S, Kunos G. Modulation of the endocannabinoid system in cardiovascular disease: Therapeutic potential and limitations. Hypertension. 2008;52: 601-7.

Palecek J. The role of dorsal columns pathway in visceral pain. Physiological Researc 2004;1: 125-30.

Papahatjis DP, Nahmias VR, Nikas SP, Schimpgen M, Makriyannis A. Design and Synthesis of (13S)-methyl-substituted arachidonic acid analogues: Templates for novel endocannabinoids Chemistry. 2010; 16: 4091-109.

Pasternak GW. Multiple opiate receptors: Déjà vu all over again. Neuropharmacology. 2004;47: 312-23.

Paterlini MG, Avitabile F, Ostrowski BG, Ferguson DM, Portoghese PS. Stereochemical requirements for receptor recognition of the $\mu$-opioid peptide endomorphin-1. Biophysical Journal 2000;78: 590-9.

Patestas MA, Gartner LP. A texbook of neuroanatomy Chapter 102013 WileyBlackwell ISBN:978-1-118-68774-1

Patricelli MP, Cravatt BF. Proteins regulating the biosynthesis and inactivation of neuromodulatory fatty acid amides. Vitamins and Hormones 2001;62: 95-131. 
Patwardhan AM, Scotland PE, Akopian AN, Hargreaves KM. Activation of TRPV1 in the spinal cord by oxidized linoleic acid metabolites contributes to inflammatory hyperalgesia. Proceedings of the National Academy of Sciences of the USA 2009;106: 18820-4.

Patwardhan AM, Akopian AN, Ruparel BN, Diogenes A, Weintraub ST, Uhlson C, et al. Heat generates oxidized linoleic acid metabolites that activate TRPV1 and produce pain in rodents. Journal of Clinical Investigation 2010;120: 1617-26.

Perlikowska R, Gach K, Fichna J, Toth G, Walkowiak B, do-Rego JC et al. Biological activity of endomorphin and [Dmt1] endomorphin analogs with six-membered proline surrogates in position 2. Bioorganic and Medical Chemistry 2009;17: 3789-94.

Perlikowska R, do-Rego JC, Cravezic A, Fichna J, Wyrebska A, Toth G, et al. Synthesis and biological evaluation of cyclic endomorphin-2 analogs. Peptides 2010;31: 339-45.

Peterson TK, Husted SE, Rybro L, Schurizek BA,Wernberg M. Urinary retention during IM and extradural morphine analgesia. British Journal of Anaesthesia 1982;54: 1175-8.

Pert CB, Pasternak G, Snyder SH. Opiate agonists and antagonist discriminated by receptor binding in brain. Science 1973;182: 359-61.

Pertwee RG, Griffin G, Fernando S, Li X, Hill A, Makriyannis C. AM630, a competitive cannabinoid receptor antagonist. Life Sciences 1995;56: 1949-55.

Pertwee RG. The central neuropharmacology of psychotropic cannabinoids. Pharmacology and Therapeutics 1988;36: 189-261.

Pertwee RG. Cannabinoid receptors and pain. Progress in Neurobiology 2001;63: 569611. 
Preston PG, Rosen MA, Hughes SC, Glosten B, Ross BK, Daniels D, et al. Epidural anesthesia with fentanyl and lidocaine for cesarean section: Maternal effects and neonatal outcome. Anesthesiology 1988;68: 938-43.

Pierce TL, Grahek MD, Wessendorf MW. Immunoreactivity for endomorphin-2 occurs in primary afferents in rats and monkey. NeuroReport 1998;9: 385-9.

Pierce TL, Wessendorf MW. Immunocytochemical mapping of endomorphin-2immunoreactivity in rat brain. Journal of Chemical Neuroanatomy 2000;18: 181-207.

Ploner M, Freund HJ, Schnitzler A. Pain affect without pain sensation in a patient with a postcentral lesion. Pain 1999;81: 211-4.

Podlogar BL, Paterlini MG, Ferguson DM, Leo GC, Demeter DA, Brown FK, et al. Conformational analysis of the endogenous mu-opioid agonist endomorphin-1 using NMR spectroscopy and molecular modeling. FEBS Letters 1998;439: 13-20.

Pomonis JD, Boulet JM, Gottshall SL, Phillips S, Sellers R, Bunton T, et al. Development and pharmacological characterization of a rat model of osteoarthritis pain. Pain 2005;114, 339-46.

Porreca F, Filla A, Burks TF. Spinal cord mediated opiate effects on gastrointestinal transit in mice. European Journal of Pharmacology 1983;86: 135-6.

Porter AC, Sauer JM, Knierman MD, Becker GW, Berna MJ, Bao J, et al. Characterization of a novel endocannabinoid, virodhamine, with antagonist activity at the CB1 receptor. Journal of Pharmacology Experiment and Therapeutics 2002;301: 1020-4.

Price TJ, Patwardhan AM, Flores CM, Hargreaves KM. A role for the anandamide membrane transporter in TRPV1-mediated neurosecretion from trigeminal sensory neurons. Neuropharmacology 2005;49: 25-39. 
Pybus A, Torda T, McQuay HJ, Moore RA. Opiates and sexual function (Letter). Nature 1984;310: 636.

Raij TT, Numminen J, Narvanen S, Hiltunen J, Hari R. Brain correlates of subjective reality of physically and psychologically induced pain. Proceedings of National Academy of the Sciences of the USA 2005;102: 2147-51.

Ramón y Cajal S. Histology of the Nervous System of Man and Vertebrates 1995 edition translated from the 1909 French edition by Swanson N and Swanson LW, Oxford University Press, New York

Ramsey IS, Delling M, Clapham DE. An introduction to TRP channels. Annual Review of Physiology 2006;68: 619-47.

Rathmell JP, Lair TR, Nauman B. The role of intrathecal drugs in the treatment of acute pain. Anasthesia and Analgesia 2005;101: 30-43.

Rawal N, Möllefors K, Axelsson K, Linghrdh G, Widman B. An experimental study of urodynamic effects of epidural morphine and of naloxone reversal. Anesthesia and Analgesia 1983;62: 641-7.

Rawal N, Nuutinen I, Raj PP, Lovering SL, Gobuty AH, Hargardine J, et al. Behavioral and histopathologic effects following intrathecal administration of butorphanol, sufentanil, and nalbuphine in sheep. Anesthesiology 1991;75: 1025-34.

Ready LB, Loper KA, Nessly M, Wild L. Postoperative epidural morphine is safe on surgical wards. Anesthesiology 1991;75: 452-6 .

Ren K, Dubner R. „Descending controll mechenisms”- Basbaum AI, Bushnell MC. In science of pain. 2009 San Diego Elsevier, ISBN:10:0123746256: 723-63. 
Rioli V, Gozzo FC, Heimann AS, Linardi A, Krieger JE, Shida CS, et al. Novel natural peptide substrates for endopeptidase 24.15, neurolysin, and angiotensin-converting enzyme. Journal of Biological Chemistry 2003;278: 8547-55.

Rexed B. The cytoarchitectonic organization of the spinal cord in the cat. Journal of Comparative Neurology 1952;96: 414-95.

Richardson JD, Kilo S, Hargreaves KM. Cannabinoids reduce hyperalgesia and inflammation via interaction with peripheral CB1 receptors. Pain 1998,75:111-9.

Ruan X. Drug - related side effects of long - term intratechal morphine therapy. Pain Physician 2007;10: 357-65.

Ruan X, Couch JP, Shah RV, Liu H, Wang F, Chiravuri S. Priapism - A rare complication following continuous epidural morphine and bupivacaine infuzion. Pain Physician 2007;10: 707-11.

Rubino T, Realini N, Castiglioni C, Guidali C, Vigano D, Marras E, et al. Role in anxiety behavior of the endocannabinoid system in the prefrontal cortex. Cerebral Cortex 2008;18: 1292-1301.

Sagar DR, Kelly S, Millns PJ, O'Shaughnessey CT, Kendall DA, Chapman V. Inhibitory effects of $\mathrm{CB} 1$ and $\mathrm{CB} 2$ receptor agonists on responses of DRG neurons and dorsal horn neurons in neuropathic rats. European Journal of Neuroscience 2005;22: $371-9$.

Salio C, Fischer J, Franzoni MF, Conrath M. Pre - and postsynaptic localizations of the CB1 cannabinoid receptor in the dorsal horn of the rat spinal cord. Neuroscience. 2002;110: 755-64.

Sakurada S, Zadina JE, Kastin AJ, Katsuyama S, Fujimura T, Murayama K, et al. Differential involvement of $\mu$-opioid receptor subtypes in endomorphin-1- and -2induced antinociception. European Journal of Pharmacology 1999; 372: 25-30. 
Sakurada S, Hayashi T, Yuhki M, Orito T, Zadina JE, Kastin AJ, et al. Differential antinociceptive effects induced by intrathecally administered endomorphin-1 and endomorphin-2 in the mouse. European Journal of Pharmacology 2001;427: 203-10.

Sakurada S, Watanabe H, Hayashi T, Yuhki M, Fujimura T, Murayama K, et al. Endomorphin analogues containing D-Pro2 discriminate different mu-opioid receptor mediated antinociception in mice. British Journal of Pharmacology 2002;137: 1143-6.

Sanudo-Pena MC, Strangman NM, Mackie K, Walker JM, Tsou K. CB1 receptor localization in spinal cord and roots, dorsal root ganglion, and peripheral nerve. Acta Pharmacologica Sinica 1999;12: 1115-20.

Sasaki M, Obata H, Kawahara K, Saito S, Goto F. Peripheral 5-HT2A receptor antagonism attenuates primary thermal hyperalgesia and secondary mechanical allodynia after thermal injury in rats. Pain 2006;122: 130-6.

Sawynok J, Reid A, Nance D. Spinal antinociception by adenosine analogs and morphine after intrathecal administration of the neurotoxins capsaicin, 6hydroxydopamine and 5,7-dihydroxytryptamine. Journal of Pharmacology and Experimetal Therapeutics 1991;258: 370-9.

Schmauss C, Yaksh TL. In vivo studies on spinal opiate receptor systems mediating antinociception. II. Pharmacological profiles suggesting a differential association of mureceptor, delta-receptor and kappa-receptor with visceral chemical and cutaneous thermal stimuli in the rat. Journal of Pharmacology and Experimental Therapeutics 1984;228: 1-12.

Schmelz M, Schmid R, Handwerker HO, Torebjörk HE. Encoding of burning pain from capsaicin-treated human skin in two categories of unmyelinated nerve fibres. Brain 2000;123: 560-71. 
Schreff M, Schulz S, Wiborny D, Hollt V. Immunofluorescent identification of endomorphin-2-containing nerve fibers and terminals in the rat brain and spinal cord. Neuroreport 1998;9: 1031-4.

Shi Z-H, Wei Y-Y, Wang C-J, Yu L. Synthesis and analgesic activities of endomorphin2 and its analogues. Chemistry and Biodiversity 2007;4: 458-67.

Shire D, Lefur G, Casellas P. Expression of central and peripheral cannabinoid receptors in human immune tissues and leukocyte subpopulations. FEBS Journal 1995;232:54-61.

Shulman MS, Sandier A, Brebner J. The reversal of epidural morphine induced somnolence with physostigmine. Canadian Anaesthetists Society Journal 1984;31: 67881.

Sidi A, Davidson JT, Behar M, Olshwang D. Spinal narcotics and central nervous system depression. Anaesthesia 1981; 36: 1044-7.

Silverman MB, Hermes SM, Zadina JE, Aicher SA. Mu-opioid receptor is present in dendritic targets of endomorphin-2 axon terminals in the nuclei of the solitary tract. Neuroscience 2005; 135: 887-96.

Simone DA, Kajander KC. Excitation of rat cutaneous nociceptors by noxious cold Neuroscience Letters 1996;213: 53-6.

Simone EJ. In searc of the opiate receptor. American Journal of Medical Sciences 1973;266: 160-8.

Singer T, Seymour B, O'Doherty J, Kaube H, Dolan RJ, Frith CD. Empathy for pain involves the affective but not sensory components of pain. Science 2004;303: 1157-62.

Simantov R, Snyder SH. Opiate receptor binding in the pituitary gland. Brain Research 1977;124: 178-84. 
Sjogren $\mathrm{P}$, Thomsen $\mathrm{AB}$, Olsen $\mathrm{AK}$. Impaired neuropsychological performance in chronic nonmalignant pain patients receiving long-term oral opioid therapy. Journal of Pain Symptom Management 2000;19: 100-8.

Sjöström S, Hartvig P, Persson MP, Tamsen A. Pharmacokinetics of epidural morphine and meperidine in humans. Anasthesiology 1987;67: 877-88.

Spampinato S, Qasem AR, Calienni M, Murari G, Gentilucci L, Tolomelli A, et al. Antinociception by a peripherally administered novel endomorphin-1 analogue containing-proline. European Journal of Pharmacology 2003;469: 89-95.

Spike RC, Puskar Z, Andrew D, Todd AJ. A quantitative and morphological study of projection neurons in lamina I of the rat lumbar spinal cord. European Journal of Neuroscience 2003;18: 2433-48.

Stella N, Schweizter P, Piomelli D. Characterisation of a second endogenous cannabinoid ligand that modulates long term potentiation (LTP) in hippocampus. Society for Neuroscience Abstract 1997;23: 264-9.

Sugiura T, Kondo S, Sukagawa A,Tonegawa T, Nakame S, Yamashita A, et al. Transacylase-mediated and phosphodiesterase-mediated synthesis of $\mathrm{N}$ arachidonoylethanolamine, an endogenous cannabinoid-recep-tor ligand, in rat brain microsomes. Comparison with synthesis from free arachidonic acid and ethanolamine. European Journal of Biochemistry 1996;240: 53-62.

Sugiura T, Kodaka T, Nakane S, Kishimoto S, Kondo S, Waku K. Detection of an endogenous cannabimimetic molecule, 2-arachidonoylglycerol, and cannabinoid CB1 receptor mRNA in human vascular cells: is 2-arachidonoylglycerol a possible vasomodulator? Biochemical and Biophysical Research and Communications 1998;243:838-43.

Sugiura T, Kondo S, Kishimoto S, Miyashita T, Nakane S, Kodaka T, et al. Evidence that 2-arachidonoylglycerol but not $\mathrm{N}$-palmitoylethanolamine or anandamide as the 
physiological ligand for the cannabinoid CB2 receptor. Comparison of the agonostic activities of various cannabinoid receptor ligands in HL-80 cells. The Journal of Biological Chemistry 2000;275, 605-12.

Standl TG, Horn E, Luckmann M, Burmeister M, Wilhelm S, Shulte AM. et al. Subarachnoid sufentanil for early postoperative pain management in orthopedic patients: A placebo-controlled, double-blind study using spinal microcatheters. Anesthesiology 2001;94: 230-8.

Steinmeyer J, Denfeldt S, Kalbhen DA. The proteoglycan metabolism, morphology an viability of articular cartilage treated with a synthetic matrix metalloprotease inhibitor. Research in Experimental Medicine 1997;2: 63-79.

Staniszewska R, Fichna J, Gach K, Toth G, Poels J, Broeck JV, et al. Synthesis and biological activity of endomorphin-2 analogs incorporating piperidine-2-, 3- or 4carboxylic acids instead of proline in position 2. Chemical Biology and Drug Design 2008;72: 91-4.

Ständer S, Schmelz M, Metze D, Luger T, Rukwied R. Distribution of cannabinoid receptor $1(\mathrm{CB} 1)$ and $2(\mathrm{CB} 2)$ on sensory nerve fibers and adnexal structures in human skin. Journal of Dermatology Science 2005;38: 177-88.

Suplita RL, Gutierrez T, Fegley D, Piomelli D, Hohmann AG. Endocannabinoids at the spinal level regulate, but do not mediate, nonopioid stress-induced analgesia. Neuropharmacology 2006;50: 372-9.

Tan B, Bradshaw HB, Rimmerman N, Srinivasan H, Yu YW, Krey JF, et al. Targeted lipidomics: Discovery of new fatty acyl amides. AAPS Journal 2006;8: 461-5

Thomas JB, Clark MS, Gioia DA. Strategic sensemaking and organizational performance: Linkages among scanning, interpretation, action, and outcomes. The Academy of Management Journal 1993;36: 239-70. 
Thompson JP, Sharpe P, Kiai S, Owen-Smith O. Effect of meloxicam on postoperative pain after abdominal hysterectomy. British Journal of Anaesthesia 2000; 84: 151-4.

Thordn T, Wattwil M. Effects on gastric emptying of thoracic epidural analgesia with morphine or bupivacaine. Anesthesia and Analgesia 1988;67: 687-94.

Todd AJ, McKenzie J. GABA-immunoreactive neurons in the dorsal horn of the rat spinal cord. Neuroscience. 1989;31: 799-806

Todd AJ. Anatomy of primary afferents and projection neurones in the rat spinal dorsal horn with particular emphasis on substance $\mathrm{P}$ and the neurokinin 1 receptor. Experimental Physioogy 2002;87: 245-9.

Tognetto M, Amadesi S, Harrison S, Creminon C, Trevisani M, Carreras M, et al. Anandamide excites central terminals of dorsal root ganglion neurons via vanilloid receptor-1 activation. Journal of Neuroscience 2001;21: 1104-9.

Tomboly C, Kover KE, Peter A, Tourwe D, Biyashev D, Benyhe S, et al. Structureactivity study on the Phe side chain arrangement of endomorphins using conformationally constrained analogues. Journal of Medical Chemistry 2004;47: 73543.

Tominaga M, Caterina MJ. Thermosensation and pain. Journal of Neurobiology 2004;61: 3-12.

Toombs JD, Follett KA, Rosenquist RW, Benton LM. Intrathecal catheter tip inflammatory mass: A failure of Clonidine to protect. Anesthesiology 2005;102: 68790.

Torda TA, Pybus DA, Liberman H, Clark M, Crawford M. Experimental comparison of extradural and i.m. morphine. British Journal of Anaesthesia 1980;52: 939-43. 
Toth G, Kramer TH, Knapp R, Lui G, Davis P, Burks TF, et al. [D-Pen2,DPen5]Enkephalin analogs with increased affinity and selectivity for delta-opioid receptors. Journal of Medical Chemistry 1990;33: 249-53.

Traynor J. Subtypes of k-opioid receptor: fact or fiction? Trends in Pharmacological Sciences 1989;10: 52-3.

Treede RD, Kenshalo DR, Gracely RH, Jones AKP. The cortical representation of pain. 1999;79: 105-11.

Trescot AM, Helm S, Hansen H, Benyamin R, Glaser SE, Adlaka R, et al. Opioids in the management of chronic non-cancer pain: An update of American Society of the Interventional Pain Physicians' (ASIPP) Guidelines. Pain Physician 2008;11: 5-62

Trevisani M, Smart D, Gunthorpe MJ, Tognetto M, Barbieri M, Campi B, et al. Ethanol elicits and potentiates nociceptor responses via the vanilloid receptor-1. Nature Neuroscience 2002;5: 546-51.

Tseng LF, Collins KA. Different mechanisms mediating tail-flick inhibition induced by endorphin, DAMGO and morphine form Rob and GiA in anesthetized rat. Journal of Pharmacology and Experimental Therapeutics 1991;257: 530-8.

Tseng LF, Narita M, Suganuma C, Mizoguchi H, Ohsawa M, Nagase H, et al. Differential antinociceptive effects of endomorphin-1 and endomorphin-2 in the mouse. Journal of Pharmacology and Experimental Therapeutics 2000;292: 576-83.

Tseng LF. Recent advances in the search for the $\mu$-opioidergic system-the antinociceptive properties of endomorphin-1 and endomorphin-2 in the mouse. Japanese Journal of Pharmacology 2002;89: 216-20.

Tsou K, Jang CS. Studies on the site of analgesic action of morphine by intracerebral. Scientia Sinica 1964;13: 1099-109. 
Tsou K, Brown S, Sanudo-Pena MC, Mackie K, Walker JM. Immunohistochemical distribution of cannabinoid $\mathrm{CB} 1$ receptors in the rat central nervous system. Neuroscience 1998;83: 393-11.

Tuboly G, Mecs L, Benedek G, Horvath G. Antinociceptive interactions between anandamide and endomorphin-1 at the spinal level. Clinical and Experimental Pharmacology and Physiology 2009;36: 400-5.

Ummenhofer WC, Arends RH, Shen DD, Bernards C. Comparative spinal distribution and clearance kinetics of intrathecally administered morphine, fentanyl, alfentanil, and sufentanil. Anesthesiology 2000;92: 739-53.

Yajiri Y, Huang LM. Actions of endomorphins on synaptic transmission of a $\delta$-fibers in spinal cord dorsal horn neurons. Journal of Biomedical Science 2000;7: 226-31.

Yaks TL, Rudy TA. Analgesia mediated by a direct spinal action of narcotics. Science 1976;192: 1357-58.

Yaksh TI, Wilson PR. Spinal serotonin terminal system mediates antinociception. Journal of Pharmacology and Experimental Therapeutics 1979;208: 446-53.

Yaksh TL, Hassenbusch S, Burchiel K, Hildebrand KR, Page LM, Coffey RJ. Inflammatory masses associated with intrathecal drug infusion: A review of preclinical evidence and human data. Pain Medicine 2002;3: 300-12.

Yaksh TL, Kokotos G, Svensson CI, Stephens D, Kokotos CG, Fitzsimmons B, et al. Systemic and intrathecal effects of a novel series of phospholipase A2 inhibitors on hyperalgesia and spinal prostaglandin E2 release. Journal of Pharmacology Experimental Therapeutics 2006;316: 466-75.

Yamazaki T, Ro S, Goodman M, Chung NN, Schiller PWA. Topochemical approach to explain morphiceptin bioactivity. Journal of Medical Chemistry 1993,36, 708-19. 
Yasaka T, Kato G, Furue H, Rashid MH, Sonohata M, Tamae A, et al. Cell-typespecific excitatory and inhibitory circuits involving primary afferents in the substantia gelatinosa of the rat spinal dorsal horn in vitro. Journal of Physiology 2007;581: 603-18.

Yu Y, Shao X, Wang Cl, Liu HM, Cui Y, Fan YZ, et al. In vitro and in vivo characterization of opioid activities of endomorphins analogs with novel constrained Cterminus: Evidence for the important role of proper spatial disposition of the third aromatic ring. Peptides 2007;28: 859-70.

van der Stelt M, Di Marzo V. Endovanilloids - putative endogenous ligands of transient receptor potential vanilloid 1 channels. European Journal of Biochemistry 2004;271: 1827-34.

van der Stelt M, Trevisani M, Vellani V, De Petrocellis L, Moriello AS, Campi B, et al. Anandamide acts as an intracellular messenger amplifying $\mathrm{Ca}^{2+}$ influx via TRPV1 channels. EMBO Journal 2005;24:3026-37.

Vella-Brincat J, Macleod AD. Adverse effects of opioids on the central nervous systems of palliative care patients. Journal of Pain and Palliative Care Pharmacotherapy 2007;1: $15-25$.

Vogt BA, Wiley RG, Jensen EL. Localization of mu and delta opioid receptors to anterior cingulated afferents and projection neurons and input/output model of mu regulation. Experimental Neurology 1995;135: 83-92.

von Voigtlander, PF, Lahti RA, Ludens JH. U-50,488: a selective and structurally novel non-mu-(kappa)-opioid agonist. Journal of Pharmacology and Experimental Therapeutics 1983;224: 7-12.

Wager TD, Davidson ML, Hughes BL, Lindquist MA, Ochsner KN. Prefrontalsubcortical pathways mediating successful emotion regulation. Neuron 2008;59: 103750. 
Wagner JA, Varga K, Kunos G. Cardiovascular actions of cannabinoids and their generation during shock. Journal of Molecular Medicine 1998;76: 824-36.

Walker JM, Huang SM, Strangman NM, Tsou K, Sanudo-Pena MC. Pain modulation by release of the endogenous cannabinoid anandamide. Proceedings of the National Academy of Sciences of the USA 1999, 96: 12198-203.

Wang JK, Nauss LA, Thomas JE. Pain relief by intrathecally applied morphine in man. Anesthesiology. 1979;50: 149-51.

Wang JB, Johnson PS, Imai Y, Persico AM, Ozenberger BA, Eppler CM. et al. cDNA cloning of an orphan opiate receptor gene family member and its splice variant. FEBS Letters 1994;348: 75-9.

Wang Cl, Guo C, Wang Yq, Zhou Y, Li Q, Ni Jm, et al. Synthesis and antinociceptive effects of endomorphin-1 analogs with C-terminal linked by oligoarginine. Peptides 2011;32: 293-9.

Waters AJ, Lumb BM. Inhibitory effects evoked from both the lateral and ventrolateral periaqueductal grey are selective for the nociceptive responses of rat dorsal horn neurones. Brain Research 1997;752: 239-49.

Wattwil M. Postoperative pain relief and gastrointestinal motility. Acta Chirurgica Scandinavica 1988;550: 140-5.

Wells DG, Davies G. Profound central nervous system depression from epidural fentanyl for extracorporcal shock wave lithotripsy. Anesthesiology 1987;67: 991-2.

Wiech K, Kalisch R, Weiskopf N, Pleger B, Stephan KE, Dolan RJ. Anterolateral prefrontal cortex mediates the analgesic effect of expected and perceived control over pain. Journal of Neuroscience 2006;26: 11501-9.

Wiesenfeld-Hallin Z, Södersten P. Spinal opiates affect sexual behaviour in rats. Nature 1984; 309: 257-8. 
Wilkinson HA, Davidson KM, Davidson RI. Bilateral anterior cingulotomy for chronic noncancer pain. Neurosurgery 1999;45: 1129-34.

Winkelmuller M, Winkelmuller W. Long-term effects of continuous intrathecal opioid treatment in chronic pain of non-malignant etiology. Journal of Neurosurgery 1996;85: 458-67.

Wittert G, Hope P, Pyle D. Tissue distribution of opioid receptor gene expression in the rat. Biochemical and Biophysical Research and Communications 1996;218: 877-81.

Wollemann M, Benyhe S, Simon J. The kappa-opioid receptor: Evidence for the different subtypes. Life Sciences 1993;52: 599-611.

Wood PB. Role of central dopamine in pain and analgesia. Expert Review of Neurotherapeutics 2008 8: 781-97.

Wu SY, Dun SL, Wright MT, Chang J-K, Dun NJ. Endomorphin-like immunoreactivity in the rat dorsal horn and inhibition of substantia gelatinosa neurons in vitro. Neuroscience 1999;89: 317-21.

Wu SY, Ohtubo Y, Brailoiu GC, Dun NJ. Effects of endomorphin on substantia gelatinosa neurons in rat spinal cord slices. British Journal of Pharmacology 2003;140: 1088-96.

Xia Y, Haddad GG. Ontogeny and distribution of opioid receptors in the rat brainstem. Brain Research 1991;549: 181-93.

Zadina JE, Hackler L, Ge LJ, Kastin AJ. A potent and selective endogenous agonist for the $\mu$-opioid receptor. Nature 1977;386: 499-502.

Zadina JE. Isolation and distribution of endomorphins in the central nervous system. Japanese Journal of Pharmacology 2002;89: 203-8. 
Zaki PA, Bilsky EJ, Vanderah TW, Lai J, Evans CJ, Porreca F. Opioid receptor types and subtypes: The delta receptor as a model. Annual Review of Pharmacology and Toxicology 1996;36: 379-401.

Zhang J, Chen C. Endocannabinoid 2-arachidonoylglycerol protects neurons by limiting COX-2 elevation. Journal of Biological Chemistry 2008;283: 22601-11.

Zygmunt PM, Petersson J, Andersson DA, Chuang H, Sorgard M, Di Marzo V, et al. Vanilloid receptors on sensory nerves mediate the vasodilator action of anandamide. Nature 1999; 400: 452-7.

\section{Acknowledgement}

I would like to express my special gratitude to my advisor, Prof. Dr. Gyongyi Horvath, who has always supported my work and put her faith in me and urged my to do better. I am thankful to her for giving the right advice at the right time, and for being a source of motivation. She encouraged and taught me throughout my Ph.D.

I would also like to thanks to Prof. Gabor Jancso for making it possible to work in the neuroscience program.

I am also hugely appreciative to co-workers of the Department of Physiology, especially to Zita Petrovszki, Gabrialla Kekes, Agnes Abraham-Tandari for being so generous with their time and energy, and for sharing their suggestions and experiences, and for being ensured me the scientific backgroud.

I owe my special thanks to my previous teacher, Prof. Dr. Kalman Toth who has raised my attention and introduced me into the world of science. He was always willing to help and give his best suggestions to my thesis and life as a good friend.

I am grateful to my friends and co-workers at the Department of Orthopedics for their help and encouragement.

Finally, but by no means least, tanks to my parents and my family (my wife and children) for the solid and peaceful background in private life. They are the most important people in my world and I dedicate this thesis to them. 


\section{Abbreviations}

ACC - anterior cingular cortex

Achc - 2-aminocyclohexanecarboxylic acid

AEA - arachidonoyl ethanolamide, anandamide

2-AG - 2-arachidonoylgycerol

ANOVA - analysis of variance

ASA - American Society of Anesthesiologist

AUC - area under the curve

$\beta$ MePhe - $\beta$-methylphenylalanine

cAMP - cyclic adenosine monophosphate

$\mathrm{CB}$ - cannabinoid

CCK - cholecystokinin

CI - confidence interval

CGRP - calcitonin gene-related peptide

CNCP - chronic non-cancer pain

CNS - central nervous system

COX-2 - cyclooxygenase-2

CSF - cerebrospinal fluid

CVLM - caudal ventrolateral medulla

CT - computed tomography

DAGL - diacylglycerol lipase

DAMGO - Tyr-D-Ala-Gly-MePhe-Gly-ol

DH - dorsal horn

DMSO - dimethylsulfoxide

Dmt - 2',6'-dimethyltyrosine

DOR - delta-opioid receptor

IASP - International Association for Study of Pain

i.c.v. - intracerebroventricular

IDD - intraspinal drug delivery

IL1 $\beta$ - interleukin $-1 \beta$

i.m. - intramuscular

i.p. - intraperitoneal 
IR - immunoreactive

i.t. - intrathecal

i.v. - intravenous

DH - dorsal horn

DRG - dorsal root ganglion

$\mathrm{ED}_{25}$ - effective dose

EM - endomorphin

EM1 - endomorphin-1 (Tyr-Pro-Trp-Phe-NH2,)

EM2 - endomorphin-2 (Tyr-Pro-Phe-Phe- $\mathrm{NH}_{2}$ )

FAAH - fatty acid amide hydrolase

FDA - US Food and Drugs Administration

FMRI - functional magnetic resonance imaging

GABA - gamma-aminobutyric acid

GDP - guanosine diphosphate

GI - gastrointestinal

Glu - glutamate

Gly - glycine

GPCR - G-protein coupled receptor

GTP - guanisine triphosphate

HP - hemopressin

Hp - hot plate

5-HT - serotonin

KOR - kappa-opioid receptor

Laminae IIi - inner zone of laminae II

Laminae IIo - outer zone of laminae II

LC - locus coeruleus

$\mathrm{LPb}$ - lateral parabrachial area

MAGL - monoacylglycerol lipase

MIA - monosodium iodoacetate

MOR - mu-opioid receptor

$\%$ MPE - \% maximum possible effect

NAC - nucleus accumbens

NADA - N-arachidonoyl-dopamine 
NE - norepinephrine

NGF - nerve growth factor

NHS - National Health Service

NK1 - neurokinin 1

NMDA receptor - N-methyl-D-aspartate receptor

NOP - nociceptin

NRM - nucleus raphe magnus

NS - nociceptive-specific

NTS - nucleus of the solitary tract

OA - osteoarthritis

ORL - orphanine receptor-like

PAG - periaqueductal grey matter

PBN - parabrachial nuclei

PE - phosphatidylethanolamine

PFC - prefrontal cortex

Phe - phenylalanine

pFPhe - para-fluorophenylalanine

Pro - proline

RVM - rostroventral medulla

PWD - paw withdrawal test

SEM - standard error of the mean

SI - primary somatosensory cortex

SII - secondary somatosensory cortex

TF - tail-flick

TM - transmembrane

TNF - tumor necrosis factor

TRP - transiens receptor potencial

Trp - tryptophane

TRPV1 - transient receptor potential vanilloid 1

Tyr - tyrozine

VPI - ventroposteroinferior

VPL - ventroposterolateral

VPM - ventroposteromedial 
VTA - ventral tegmental area

WDR - wide dynamic range neuron 